\title{
Free at Last? Judicial Discretion and Racial Disparities in Federal Sentencing
}

\section{Citation}

Crystal S. Yang, Free at Last? Judicial Discretion and Racial Disparities in Federal Sentencing (June 2013).

\section{Permanent link}

http://nrs.harvard.edu/urn-3:HUL.InstRepos:10985166

\section{Terms of Use}

This article was downloaded from Harvard University's DASH repository, and is made available under the terms and conditions applicable to Other Posted Material, as set forth at http:// nrs.harvard.edu/urn-3:HUL.InstRepos:dash.current.terms-of-use\#LAA

\section{Share Your Story}

The Harvard community has made this article openly available.

Please share how this access benefits you. Submit a story.

\section{Accessibility}




\title{
FREE AT LAST? JUDICIAL DISCRETION AND RACIAL DISPARITIES IN FEDERAL SENTENCING
}

\author{
Crystal S. Yang*
}

\begin{abstract}
The Federal Sentencing Guidelines were created to reduce unwarranted sentencing disparities among similar defendants. This paper explores the impact of increased judicial discretion on racial disparities in sentencing after the Guidelines were struck down in United States $v$. Booker (2005). Using data on the universe of federal defendants, I find that black defendants are sentenced to almost two months more in prison compared to their white counterparts after Booker, a 4\% increase in average sentence length. To identify the sources of racial disparities, I construct a dataset linking judges to over 400,000 defendants. Exploiting the random assignment of cases to judges, I find that racial disparities are greater among judges appointed after Booker, suggesting acculturation to the Guidelines by judges with experience sentencing under a mandatory regime. Prosecutors also respond to increased judicial discretion by charging black defendants with longer mandatory minimums.
\end{abstract}

JEL Classifications: J15, K14, K40

*Support was provided by Harvard Law School's John M. Olin Center for Law, Economics, and Business and the Multidisciplinary Program on Inequality and Social Policy at Harvard. I am very grateful to Lawrence Katz for detailed feedback on this project. I also thank Raj Chetty, Will Dobbie, Claudia Goldin, Louis Kaplow, Ilyana Kuziemko, Jeff Miron, J.J. Prescott, Shayak Sarkar, Steven Shavell, and Kate Stith for helpful comments and suggestions, and participants in the Harvard University Labor Economics/Public Finance Seminar, Harvard Law School Law and Economics Seminar, and American Law and Economics Association Annual Meeting. The Transactional Records Access Clearinghouse (TRAC) at Syracuse University, in particular Sue Long, generously provided sentencing data for use in this project in my role as a TRAC Fellow of the Center. All errors are my own. E-mail: csyang@uchicago.edu. 


\section{INTRODUCTION}

Sentencing disparities by race, gender, education, and socioeconomic status are prevalent in the federal criminal justice system. Black defendants are sentenced to five months longer in prison than white defendants who commit similar offenses and have similar observable demographic traits and criminal history. Male defendants are sentenced to over five months more in prison than similar female defendants, and defendants with lower educational attainment and income receive significantly longer sentences than otherwise similar offenders (Mustard 2001). Even within the same court, judges appear to vary significantly in their treatment of defendant race (Abrams et al. 2012), suggesting that racial disparities in the the criminal justice system may be a source of the overrepresentation of blacks in the prison population.

In response to concerns that judges were introducing unwarranted disparities in sentencing (Frankel 1973), Congress adopted the United States Sentencing Guidelines (Guidelines) under the Sentencing Reform Act (SRA) of 1984. While the Guidelines reduced inter-judge sentencing disparities in its early years (Anderson, Stith, and Kling 1999), it was criticized for its rigidity (e.g., Freed 1992 and Stith 2008), and for shifting power to prosecutors in their charge and plea bargaining decisions (Stith and Cabranes 1998, Alschuler 1978, Nagel and Schulhofer 1992).

After almost two decades of mandatory Guidelines sentencing, the Guidelines were struck down in United States v. Booker, 543 U.S. 220 (2005). Booker greatly increased the degree of judicial discretion afforded to judges (See, e.g., Berman 2005), with subsequent cases further increasing judicial discretion by reducing the degree of appellate scrutiny. Empirical work on the impact of Booker suggests increases in inter-judge sentencing disparities (Scott 2010), but has yielded mixed results on racial disparities, with some researchers finding large racial disparities in the aftermath of Booker (United States Sentencing Commission 2006, 2010) and others finding no significant impact on racial disparities in sentence length (Ulmer et al. 2010). ${ }^{1}$ Some scholars have even argued that judicial discretion may actually mitigate recent increases in racial disparities (Fischman and Schanzenbach 2012, Starr and Rehavi 2012). ${ }^{2}$ In light of possible evidence

\footnotetext{
${ }^{1}$ Both studies fail to account for district court differences, interactions between offender criminal history and offense severity, and condition on endogenous decisions to deviate from the Guidelines, which explain a large portion of increased racial disparities after Booker.

${ }^{2}$ Starr and Rehavi (2012) find no change in racial disparities in the immediate aftermath of Booker using a regression discontinuity approach, but their local estimate is unable to account for racial disparities that emerge after later changes in appellate review, as well as the entrance of new judges to the federal bench.
} 
of increasing disparities post Booker, the United States Sentencing Commission and policymakers have considered possible ways to constrain judicial discretion, such as "resurrecting" the mandatory Guidelines (Sessions 2011).

This paper estimates the impact of increased judicial discretion via Booker on racial disparities in federal sentencing using data on the universe of defendants sentenced between 1994-2009. I use a differences-in-differences (DD) methodology to compare the sentence disparities between similar defendants within a district court before and after Booker and find that racial disparities increase significantly after Booker controlling for extensive offender and crime characteristics. The black-white sentencing gap increases by almost 2 months in the post Booker period, a 75\% increase in the baseline racial gap, and a $4 \%$ increase in the average sentence length. Increased racial disparities in sentence length can be attributed to black defendants being more likely to be sentenced above the Guidelines recommended range, and less likely to be sentenced below the Guidelines recommended range, compared to similar white offenders. Even conditional on being sentenced within the Guidelines range, black defendants receive significantly longer sentences than similar white defendants.

The results are robust to controlling for different racial trends in sentencing outcomes, and changes induced by other laws and court decisions. Racial disparities in sentencing persist after accounting for differential treatment of offenders based on other observable traits after Booker, such as educational attainment and criminal history. I also find evidence that the racial sentencing gap expands after periods of more deferential appellate review, suggesting that judges are particularly responsive to changes in the likelihood of appellate reversal. A potential threat to identification is the possibility of endogenous measures of offense severity. To account for this concern, I link defendants across datasets from the arrest to sentencing stage, and obtain highly detailed measures of arrest offense, a plausibly exogenous measure of offense severity. Results are robust to controlling for arrest offense, suggesting that differential fact-finding at the sentencing stage cannot fully explain the increase in racial disparities.

Next, I examine the sources of increasing disparities after Booker by studying how different types of judges respond to increased judicial discretion. Many scholars have suggested that judges have different sentencing philosophies (e.g., Hofer, Blackwell, and Ruback 1999), which may be affected by the standard of appellate review (Fischman and Schanzenbach 2011), with correlations 
between sentencing practices and judicial characteristics such as race, gender, and political affiliation (Welch 1988, Schanzenbach 2005, Schanzenbach and Tiller 2007, Schanzenbach and Tiller 2008). However, prior empirical research on inter-judge disparity and the impact of judicial demographics on sentencing practices has been hampered by the lack of judge identifiers. Relying on aggregate district-level variation in judicial demographics can lead to biased estimates if districts with different judicial compositions differ in ways that affect all judges within the district court.

I surmount these issues by utilizing a novel dataset constructed for this study. Matching three data sources, I construct a dataset of over 400,000 criminal defendants linked to sentencing judge from fiscal years 2000-2009. Given that cases are randomly assigned to judges within a district court, any difference in sentencing practices across judges can be attributable to judge differences, rather than case composition. Exploiting the random assignment of cases to judges in this dataset, I find that increases in racial disparities after Booker are larger among post Booker appointed judges, even after accounting for the fact that these judges are George W. Bush appointees. Nor are the sentencing patterns of post Booker judges explained by the fact that these judges are relatively "new" to federal sentencing, based on comparisons to "new" judges in earlier cohorts. My findings suggest that judges with experience sentencing under the Guidelines may have become relatively acculturated to the Guidelines regime, compared to newer judges who began their tenure in a post Booker regime.

I conclude by considering the impact of judicial discretion on other actors in the criminal justice system. Arrest, charge, trial and plea bargaining decisions made earlier in the process are all ripe avenues for unwarranted bias (Anwar et al. 2012, Rehavi and Starr 2012). After Booker, prosecutors have commented that they are far less willing to forego charging mandatory minimums when judges ultimately sentence defendants to terms far below the Guidelines recommended minimum sentence. Consistent with this story, I find evidence that increased judicial discretion via Booker changes the prosecutorial treatment of statutory mandatory minimums, which Booker left intact. Black offenders are far more likely to be charged with mandatory minimums than similar white offenders, and after Booker, black defendants are significantly more likely to face mandatory minimums that exceed their Guidelines minimum compared to white defendants, consistent with prosecutors attempting to rein in judicial discretion.

The paper is structured as follows. Section II provides a brief legal background of the Guide- 
lines and the Booker decision. Section III describes the data and presents summary statistics. Section IV presents a simple conceptual framework for judicial sentencing. Section V provides the empirical methodology. Section VI presents results, and Section VII concludes.

\section{LEGAL BACKGROUND}

\section{II.A. Adoption of the United States Sentencing Guidelines}

For over a century prior to the adoption of the Guidelines, judges had virtually unfettered discretion to determine the lengths of sentences. A 1977 study of Virginia state district court judges revealed that while judges generally agreed on the verdict in legal cases, they applied radically different sentences (Austin and Williams 1977). A 1988 study of federal courts similarly found that white collar offenders who committed similar offenses received very different sentences depending on the court in which they were sentenced (Wheeler at al. 1988).

By the 1970s, the legal community and public expressed alarm at the widespread disparities in criminal sentencing that resulted from this indeterminate sentencing regime (Frankel 1973). Some members of the public argued that judges and parole boards endangered public safety with lenient sentencing of criminals (Tonry 2005). Others were distressed by inequitable and arbitrary treatment within the criminal justice system. The American Friends Service Committee claimed that decreasing discretion among judges was the only way to eliminate racial discrimination in the criminal justice system (American Friends Service Committee 1971).

Policymakers also recognized that judges were often "left to apply [their] own notions of the purposes of sentencing," leading to "an unjustifiably wide range of sentences to offenders convicted for similar crimes" (S. Rep. No. 98-225 1983). In order to eliminate unwarranted sentencing disparities "among defendants with similar records who have been found guilty of similar criminal conduct," Congress created the United States Sentencing Commission to adopt and administer the Guidelines. Part of the SRA of 1984, the Guidelines were applied to all federal offenses committed after November 1, 1987, and prohibited courts from using race, sex, national origin, creed, religion, and socioeconomic status in sentencing decisions.

Under the Guidelines, federal district court judges assign each crime to one of 43 offense levels, and assign each defendant to one of six criminal history categories. The more serious the 
offense and the greater the harm associated with the offense, the higher the base offense level. For example, trespass offenses are assigned a base offense level of four, while kidnapping is assigned a base offense level of 32. From a base offense level, the final offense level is calculated by adjusting for applicable offense and defendant characteristics. Relevant adjustments under Chapter Two of the Guidelines include the amount of loss involved in the offense, use of a firearm, and the age or condition of the victim. Chapter Three allows for further adjustments based on aggravating or mitigating factors, such as obstruction of justice or a defendant's acceptance of responsibility.

The criminal history category reflects the frequency and severity of a defendant's prior criminal convictions, predictive of recidivism risk. To determine a defendant's criminal history category, a judge adds points for prior sentences in the federal system, 50 state systems, all territories and foreign or military courts. For example, three points are added for each prior sentence of imprisonment exceeding one year and one month, and two points are added for each prior sentence of imprisonment of at least 60 days and less than one year and one month. Two points are also added if the defendant committed the instant offense under any criminal justice sentence. These points are then converted into a criminal history category.

The intersection of the final offense level and criminal history category yields a fairly narrow Guidelines recommended sentencing range, where the top of the range exceeds the bottom by the greater of either six months or 25\% (See Online Appendix Table A1 for the Guidelines sentencing chart). If a judge determines that there are aggravating or mitigating circumstances that warrant a departure from the Guidelines, she would have to justify her reasons for departure to the appellate court, but in general the Guidelines were treated as sufficiently mandatory prior to Booker. Before Booker, judges could only consider factors such as a defendant's age, education, employment history, in deciding the sentence length for within range sentences. After sentencing, the government is permitted to appeal a sentence resulting in a departure below the Guidelines range, and the defendant can appeal an upward departure. ${ }^{3}$

\footnotetext{
${ }^{3}$ There are numerous other ways in which Congress has attempted to limit unwarranted disparities in sentencing. Beginning in 1984, and subsequently 1986 and 1988, Congress enacted a series of mandatory minimum statutes directed at drug and firearms offenses. In 2003, Congress also passed the PROTECT Act to curtail judicial departures due to a concern that the standard for appellate review of departures had led to undesirably high rates of departures for child sex offenses.
} 


\section{II.B. Challenges to the Mandatory Guidelines Regime}

The constitutionality of mandatory sentencing guidelines was first questioned in reference to the Washington State Sentencing Guidelines. In Blakely v. Washington, 542 U.S. 296 (2004), the Supreme Court held that the Sixth Amendment right to a jury trial prohibited judges from increasing a defendant's sentence beyond the statutory maximum based on facts other than those decided by the jury beyond a reasonable doubt. As a result, Washington's mandatory sentencing guidelines were struck down. Shortly after, the reasoning of Blakely was applied to the United States Sentencing Guidelines.

In United States v. Booker, the mandatory Guidelines were also found unconstitutional under the Sixth Amendment. The Booker ruling, however, did not apply to mandatory minimum sentences enacted by Congress. Rather than invalidating the Guidelines, the Supreme Court held that the Guidelines would be "effectively advisory," as opposed to mandatory. The Court explained that "district courts, while not bound to apply the Guidelines, must consult those Guidelines and take them into account when sentencing."

In the aftermath of Booker, circuit courts reached a consensus that sentencing must begin with the calculation of the applicable Guidelines range. Today, after a sentencing judge has calculated the Guidelines range, she must consider seven factors under 18 U.S.C. \$3553(a) before imposition of punishment: (1) the nature and circumstances of the offense and the history and characteristics of the defendant, (2) the need for the sentence imposed, (3) the kinds of sentences available, (4) the kinds of sentence and the sentencing range established, (5) any pertinent policy statement issued by the Sentencing Commission, (6) the need to avoid unwarranted sentence disparities among defendants with similar records who have been found guilty of similar conduct, and (7) the need to provide restitution to any victims of the offense.

Subsequent Supreme Court decisions further weakened the effect of the Guidelines on criminal sentencing by reducing the degree of appellate review. In Rita v. United States, 551 U.S. 338 (2007), the Court held that a sentence within the Guidelines recommended range could be presumed "reasonable" because a "judge who imposes a sentence within the range recommended by the Guidelines thus makes a decision that is fully consistent with the Commission's judgment in general." In Gall v. United States, 552 U.S. 38 (2007), the Court held that federal appeals courts 
could not presume that a sentence outside the range recommended by the Guidelines was unreasonable. Concurrent with the Gall decision, the Court in Kimbrough v. United States, 552 U.S. 85 (2007), held that federal district court judges have the discretion to impose sentences outside the recommended Guidelines range due to policy disagreements with the Sentencing Commission, such as the disparate treatment of crack and powder cocaine offenses - the so-called "100-to-1 ratio."

\section{DATA}

This paper utilizes data from three sources: (1) the United States Sentencing Commission, (2) the Transactional Records Access Clearinghouse, and (3) the Federal Judicial Center. I describe each dataset in turn.

\section{III.A. United States Sentencing Commission}

I use data from the United States Sentencing Commission (USSC) on records of all federal offenders sentenced pursuant to the Sentencing Guidelines and Policy Statements of the SRA of 1984 in fiscal years 1994-2009 (October 1, 1993 - September 30, 2009). ${ }^{4}$ These data include demographic, Guidelines application, and sentencing information on federal defendants, but defendant and judge identifiers are redacted. This information is obtained from numerous documents on every offender: Indictment, Presentence Report, Report on the Sentencing Hearing, Written Plea Agreement (if applicable), and Judgment of Conviction.

Demographic variables include defendant's race, gender, age, citizenship status, educational attainment, and number of dependents. Data is also provided on the primary offense type, with a total of 35 offense categories. Offense level variables include the base offense level, the base offense level after Chapter Two adjustments and the final offense level after Chapter Three adjustments. Criminal history variables include whether the defendant has a prior criminal record, and whether armed career criminal status, or career offender status is applied, which are subject to mandatory minimums. Data is also provided on the total number of criminal history points applied and the final criminal history category.

\footnotetext{
${ }^{4}$ Over $90 \%$ of felony defendants in the federal criminal justice system are sentenced pursuant to the SRA of 1984 and all cases are assessed to be constitutional.
} 
For each offender, there is a computed Guidelines range, and a Guidelines range adjusted for applicable mandatory minimums. From these variables, I construct indicator variables for above range and below range departures from the Guidelines, as well as months of departure, conditional on an above or below range departure. ${ }^{5}$ Information is also provided on whether the offense carries a mandatory minimum sentence under various statutes, and whether departures from the statutory minimum are granted, either under a substantial assistance motion or application of the safety valve (described in greater detail later). Sentencing characteristics include the district court in which sentencing occurred (94 total), in addition to the sentencing month and year. ${ }^{6}$ Data is also available on whether a case is settled by plea agreement or trial. Sentencing outcomes include incarceration or probation, sentence length, receipt of supervised release, and length of supervised release.

I apply several sample restrictions. First, I drop individuals sentenced to life imprisonment, about $0.5 \%$ of the sample. Second, I drop individuals with missing or invalid criminal records (offense level, criminal history category, and offense type), about $6 \%$ of the sample. Third, I exclude individuals missing race, about $0.2 \%$ of the sample.

Table I presents summary statistics for the main variables from the USSC data. Panel A indicates that $83 \%$ of the defendants in the dataset are incarcerated versus receiving probation. Those who are not incarcerated serve an average of 29 months of probation. The average unconditional sentence length is approximately 49 months. Conditional on incarceration, the average sentence length is 57 months. Approximately $30 \%$ of cases carry a statutory minimum and only $4 \%$ of cases are settled by trial. After imprisonment, defendants serve an average of 38 months of supervised release.

In the dataset, $32 \%$ of defendants are white, $26 \%$ black and $38 \%$ Hispanic. ${ }^{7}$ About $32 \%$ of the defendants are non U.S. citizens. Defendants have on average 1.6 dependents, and almost a majority have less than a high school degree. Over $85 \%$ of the defendants are male. Defendants are approximately 34 years of age. Most of the defendants have had some previous interaction

\footnotetext{
${ }^{5}$ Technically, deviations from the Guidelines range are no longer "departures" after the Guidelines became advisory, but I use this term to maintain consistency.

${ }^{6}$ USSC data prior to 2004 actually includes information on the exact sentencing day, but this variable is not available in later years.

${ }^{7}$ The remaining race category is defendants classified as "other" race, which is comprised primarily of Native Americans.
} 
with the criminal justice system, as $75 \%$ have some prior criminal history. The most common offense is drug trafficking, followed by immigration, fraud, firearms, and larceny. Drug trafficking represents about $39 \%$ of the cases, followed by immigration offenses which comprise $18 \%$ of the cases. In terms of Guidelines range calculations, defendants have an average final criminal history score of 2.36, and a final offense level of 18.84. This criminal history category and offense level combination yield an average Guidelines recommended range of 30-37 months in prison.

\section{III.B. Transactional Records Access Clearinghouse}

The Transactional Records Access Clearinghouse (TRAC) provides sentencing data obtained through FOIA requests. The data do not contain defendant demographics, offense characteristics, and Guidelines application information, but defendants are linked to the sentencing judge. To link defendant and crime characteristics to sentencing judge, I match sentencing records from the USSC to data provided by TRAC. By district court, matching is conducted on several key variables: sentencing year, sentencing month, offense type, sentence length in months, probation length in months, amount of monetary fine, whether the case ended by trial or plea agreement, and whether the case resulted in a life sentence. For defendants sentenced prior to fiscal year 2004, I also match on exact sentencing day. ${ }^{8}$ I successfully match over $90 \%$ of all cases from fiscal years 2000-2009.

\section{III.C. Federal Judicial Center}

To provide information on judge characteristics, I match the USSC and TRAC combined data to judge biographical data from the Federal Judicial Center. Federal district judges are Article III judges who serve life term tenures. New appointments are generally made when a judge retires or dies. ${ }^{9}$ As of the current day, there are a total of 678 Article III district judgeships. The largest district court is the Southern District of New York with 28 authorized judgeships. The majority of other district courts have between two to seven judgeships.

I obtain information on judge race, gender, political affiliation of appointing president, and commission year. Applying the same sample restrictions as described in Section III.A, the final

\footnotetext{
${ }^{8}$ Results are unchanged matching on the same variables across all years.

${ }^{9}$ On a few occasions, Congress has also increased the number of judgeships within a district in response to changing population or caseload.
} 
matched dataset consists of 440,025 cases resulting in prison sentences from fiscal years 20002009. ${ }^{10}$ This unique dataset permits an examination of judicial demographic characteristics on sentencing practices in the wake of increased judicial discretion via Booker. Panel B of Table I presents summary statistics on this matched dataset. Of judges active between 2000-2009, 19\% are female, and over $75 \%$ are white. Black judges represent approximately $8 \%$ of the share of all judges. Judges appointed by Democratic presidents represent $44 \%$ of all judges.

\section{Conceptual Framework of Judicial Sentencing}

This section provides a very simplified framework for analyzing judicial sentencing, similar to that used by Gennaioli and Shleifer (2008). The framework considers two countervailing forces on judicial sentencing: (1) a judge's preferences for sentencing according to her tastes and (2) costs associated with exercising discretion.

Consider a judge who is assigned to a defendant with a true harm or risk of recidivism, $r$. Let the Guidelines sentence for a defendant with risk $r$ be $s^{*}(r)$. Now suppose that the judge would prefer to sentence the defendant to $s^{j}(r)$, such that $s^{j}(r) \neq s^{*}(r)$. The judge may prefer to impose $s^{j}(r)$ because sentencing a defendant in a particular way can increase the judge's utility by advancing her political and ideological goals, or other personal goals. ${ }^{11}$

Assume that a judge suffers disutility from sentencing $s \neq s^{j}(r)$, such that a judge who sentences $s$ experiences loss of

$$
L=\frac{\left(s-s^{j}(r)\right)^{2}}{2}
$$

If judges have sentencing preferences that deviate from the Guidelines and were left unconstrained, a judge would set $s=s^{j}(r)$ and one would likely observe large inter-judge disparities in sentencing. Consistent with this prediction, Posner (2005) suggests that the large variances in federal sentences prior to the adoption of the Guidelines were likely due to differing judicial attitudes towards personal responsibility and deterrence.

However, various mechanisms constrain judges from deviating from recommended sentences.

\footnotetext{
${ }^{10}$ The Federal Judicial Center does not collect demographic information on judges in 3 districts: Guam, Virgin Islands, and Northern Mariana Islands.

${ }^{11} 65 \%$ of federal district judges in a 2010 USSC survey indicated that they thought the departure policy statements in the Guidelines Manual were too restrictive, indicating that many judges prefer to deviate from the Guidelines.
} 
For one, mandatory rule-based sentencing under a Guidelines regime constrains judge sentencing. Another constraint on judge decision-making comes from appellate review. A high reversal rate is not only administratively burdensome, but also potentially harms a trial judge's prospects for promotion to the appeals court (Posner 2005).

Thus, a judge sentencing away from the Guidelines recommended sentence also incurs a cost associated with reversal. Assume that pre Booker, a judge faced a cost $C=0$ if $s=s^{*}(r)$ and $C=\infty$ if $s \neq s^{*}(r)$. Essentially, the Guidelines were treated as mandatory, implying very high costs to exercising discretion. In this pre Booker regime, one would see very little deviation from the Guidelines. ${ }^{12}$

After Booker, the Guidelines were no longer binding, but judges still faced the prospect of reversal upon appellate review. To capture this idea, assume that the cost of exercising discretion in the post Booker regime is

$$
C=p \frac{\left(s^{j}(r)-s^{*}(r)\right)^{2}}{2}
$$

where $p$ is the probability of appellate reversal and $\frac{\left(s^{j}(r)-s^{*}(r)\right)^{2}}{2}$ is the reputational cost associated with reversal.

Given a defendant with true risk $r$, a judge therefore sets a sentence $s(r)$ to minimize $\frac{\left(s-s^{j}(r)\right)^{2}}{2}+$ $p \frac{\left(s^{j}(r)-s^{*}(r)\right)^{2}}{2}$, setting

$$
s(r)=\frac{s^{j}(r)+p s^{*}(r)}{1+p}
$$

Thus, the judge imposes a sentence that is a weighted average of his ideal and the Guidelines recommended sentence. If $p=0$, he sets the sentence to his ideal. The greater the probability of reversal, $p$, the more the judge sentences the defendant closer to the Guidelines sentence.

From a Guidelines regime to Booker, the total cost of exercising discretion $C$ falls substantially for judges who want to depart from the Guidelines sentence. Rita, Gall, and Kimbrough later reduced the level of appellate review from de novo to substantial abuse of discretion, intuitively lowering $p$, the probability of appellate reversal. Indeed, the probability of reversal on sentencing matters fell from 36\% in 2006 (under de novo review), to $26 \%$ in 2008 (under abuse of discretion review). ${ }^{13}$ Thus, as the cost of exercising discretion falls after Booker, the model predicts that

\footnotetext{
${ }^{12}$ The rate of departure from the Guidelines was less than $15 \%$ in the early 1990 s.

${ }^{13}$ I calculate rate of appellate reversals using yearly data on the universe of criminal appeals from the USSC. Reversal is defined as all reversals and remands on appeals arising out of sentencing issues.
} 
judges would immediately impose sentences that deviate from the Guidelines sentence. As the probability of appellate reversal falls under Rita, Gall, Kimbrough, the costs of discretion fall even more, and one would expect to see further deviations from the Guidelines. If the probability of appellate reversal under de novo review was a binding constraint on judges, one would expect to see relatively larger changes in sentencing after Rita, Gall, and Kimbrough than in the immediate aftermath of Booker.

\section{EMPirical Methodology}

The Booker case was decided on January 12, 2005, and applied immediately to all future cases and prior cases that had not reached sentencing. This paper exploits the timing of this decision to estimate the effect of increased judicial discretion on racial disparities in sentencing outcomes. I use a differences-in-differences (DD) methodology to compare the sentence disparities between similar defendants within a district court before and after Booker.

The main specification is of the form:

$$
\begin{array}{r}
Y_{i j k d t m}=\beta_{0}+\beta_{1} * \text { Booker } * \text { Race }_{i}+\beta_{2} * \text { Booker }+\beta_{3} * \text { Race }+\boldsymbol{\beta}_{\mathbf{4}} * \mathbf{X}_{i}+\beta_{5} * Z_{i} \\
+ \text { Guide }_{i j k}+\text { Offtype }_{i}+\gamma_{d}+\delta_{t}+\gamma_{d} * \delta_{t}+\lambda_{m}+\epsilon_{i j k d t m}
\end{array}
$$

where $Y_{i j k d t m}$ is a sentencing outcome for defendant $i$, with criminal history category $j$ and offense level $k$, sentenced in district court $d$ in year $t$ and month $m$. Main outcomes include sentence length measured in months, a binary indicator for whether the defendant was sentenced above range (such that the sentence length is greater than the prescribed Guidelines maximum), a binary indicator for below range sentencing (sentence length less than the prescribed Guidelines minimum), and sentence length conditional on above, below, or within range sentencing. Additional outcomes include a binary indicator for incarceration, probation length, receipt of supervised release, term of supervised release, application of a statutory minimum, and departures from statutory minimums.

The main coefficient of interest is $\beta_{1}$, which captures the impact of Booker on racial gaps in sentencing outcomes. Booker is an indicator variable for defendants sentenced after the Booker decision. ${ }^{14}$ Race $_{i}$ is a dummy variable for defendant i's race: white, black, Hispanic, or other.

\footnotetext{
${ }^{14}$ For defendants sentenced in January 2005, the USSC data contains a variable denoting whether the case was heard
} 
$\mathbf{X}_{i}$ comprises a vector of demographic characteristics of the defendant including gender, age, age squared, educational attainment (less than high school, high school graduate, some college, college graduate), number of dependents, and citizenship status. $Z_{i}$, an indicator variable for whether the offense carries a mandatory minimum. ${ }^{15}$

Guide $_{i j k}$ includes dummy variables for criminal history category $j$ and offense level $k$, and each unique combination of criminal history category and offense level. The interaction captures differential sentencing tendencies at each unique cell of the Guidelines grid (258 total). To proxy for underlying offense seriousness and all aggravating and mitigating factors, I control for final offense level. I also control for final criminal history category. Of ftype $i$ is a dummy variable for offense type.

The specification also includes district court fixed effects $\left(\gamma_{d}\right)$, sentencing year fixed effects $\left(\delta_{t}\right)$, and sentencing month fixed effects $\left(\lambda_{m}\right)$. I also control for district by year fixed effects to control for district trends over time. As a robustness check, race specific linear trends are included to account for preexisting trending differences in sentencing outcomes between defendants of different races. All standard errors are clustered at the district court level to account for serial correlation.

To analyze the differential sentencing practices of certain types of judges, I use a differencesin-differences-in-differences (DDD) methodology. The DDD methodology captures how judges differ in their relative treatment of similar black and white defendants in response to increased judicial discretion, compared to other judges within the same district court. Because cases are randomly assigned to judges within a district court, judge identifiers allow one to compare judges within the same court, capturing judge differences in sentencing rather than different caseloads. ${ }^{16}$

I identify the sources of increasing racial disparities post Booker using a specification of the

prior to or after the Booker decision.

${ }^{15}$ Controlling for the application of a mandatory minimum is important because of large differences by race. Moreover, the application of mandatory minimums is not endogenous to Booker (See Table VI).

${ }^{16}$ According to the Administrative Office of the United States Courts, "The majority of courts use some variation of a random drawing." I also test for random assignment in Section VI.F. 
form:

$$
\begin{aligned}
& Y_{i j k d t m}=\beta_{0}+\alpha_{1} * \text { Judge }_{i} * \text { Race }_{i} * \text { Booker }+\alpha_{2} * \text { Judge }_{i} * \text { Race }_{i}+\alpha_{3} * \text { Judge }_{i} * \text { Booker } \\
& +\beta_{1} * \text { Booker } * \text { Race }_{i}+\beta_{2} * \text { Booker }+\beta_{3} * \text { Race }+\boldsymbol{\beta}_{\mathbf{4}} * \mathbf{X}_{i}+\beta_{5} * Z_{i}+\text { Guide }_{i j k} \\
& + \text { Offtype } e_{i}+\gamma_{d}+\delta_{t}+\gamma_{d} * \delta_{t}+\lambda_{m}+\epsilon_{i j k d t m}
\end{aligned}
$$

where $J u d g e_{i}$ includes judicial demographics such as race, gender, political affiliation, an indicator for pre vs. post Guidelines appointment, and an indicator for pre vs. post Booker appointment. The coefficient $\alpha_{1}$ captures the impact of particular judicial characteristics on racial disparities in the wake of Booker.

\section{RESULTS}

\section{VI.A. Sentence Length}

Figure I presents graphical evidence of trends in sentence length by defendant race in the raw data. Figure I indicates no preexisting trending differences in sentence lengths across defendants of different races. However, the trend in the gap in sentence length between black and white defendants changes post Booker as sentence lengths for black and white defendants diverge. The evidence is even more striking excluding cases with mandatory minimums, where it is apparent that sentence lengths for white defendants decrease post Booker, while black sentence lengths continue to rise, increasing the racial disparities in sentence length.

Table II presents the regression results for the impact of increased judicial discretion via Booker on disparities in sentence length. The coefficients on defendant demographics are consistent with prior findings regarding disparities in sentencing. On average, black offenders face an approximately 3 month longer sentence length than comparable white offenders, who are the omitted category. Hispanic offenders receive over a 1 month longer prison sentence compared to similar white offenders. Additionally, non US citizens face about a 1.5 month longer prison sentence compared to US citizens. Defendants with greater educational attainment receive shorter months in

prison, compared to defendants with less than a high school degree (the omitted category). I also 
find large sentencing disparities by gender. Female defendants receive over 5 months less in prison compared to male offenders. Additionally, defendant age is positively correlated with sentence length, while number of dependents is negatively associated with sentence length. The application of a mandatory minimum on average results in a 23 month longer sentence.

The coefficients on the Booker indicator interacted with defendant race suggest growing racial disparities post Booker. Column 1 suggests that black offenders receive an approximately 2 month longer sentence after Booker compared to white offenders, over a $70 \%$ increase in the racial gap in sentence length, and a $4 \%$ increase in the average sentence length for all offenders. Post Booker, Hispanics offenders receive about a 1.5 month longer sentence compared to similar white offenders, an approximately $3 \%$ increase in the average sentence length for all offenders.

I present several robustness checks in Table II. Column 2 controls for possible differential effects of the PROTECT Act on racial disparities in sentencing outcomes. Column 3 accounts for potential effects of the 2007 Rita/Gall/Kimbrough decisions on racial disparities. ${ }^{17}$ Column 3 indicates that while racial disparities first emerge in the immediate aftermath of Booker, they grow larger following Rita, Gall, and Kimbrough, suggesting that judges are particularly responsive to more deferential appellate review.

Column 4 includes race specific linear trends. Column 5 includes race trends and adds a full set of time effects - sentencing month interacted with sentencing year. Finally, in Online Appendix Table A3, I replicate specification (4) for ten placebo periods prior to Booker. Table A3 indicates that the changes in racial disparities post Booker are much larger than those around placebo periods. Overall, these alternate specifications indicate that increases in racial disparities in the aftermath of Booker are highly robust.

While racial disparities in sentence length have increased as a whole, a more disaggregated analysis reveals that the growing racial disparities after Booker do not appear uniformly across all offenses. Online Appendix Table A4 presents results on sentence lengths disaggregated into the most prevalent seven offenses, which comprise $84 \%$ of all offenses in the dataset. Racial disparities increase significantly among defendants convicted of drug trafficking offenses, controlling for primary type of drug, and fraud offenses. Black and Hispanic defendants convicted of these of-

\footnotetext{
${ }^{17}$ I control for possible differential effects of the PROTECT Act and Rita/Gall/Kimbrough by interacting indicators for these court decisions with defendant race dummies. Although not shown in Table II, the passage of the PROTECT Act did not change racial disparities in sentencing. This finding is also confirmed by Freeborn and Hartmann (2010).
} 
fenses receive 1.5-2 months longer in prison compared to their white counterparts in the aftermath of Booker.

\section{VI.B. Departures from the Guidelines}

Table III presents results on how Booker impacted departures from the Guidelines. Column 1 replicates specification (4) of the sentence length results from Table II. Column 2 indicates that post Booker, black defendants are sentenced at greater rates above range than white defendants, approximately $2 \%$. However, conditional on above range sentencing, black defendants receive about the same number of months above range compared to white defendants.

Column 4 shows that below range departures increase generally post Booker by over $8 \%$ for all defendants. The high rate of below range departures following Booker may be the result of judicial discontent with the mandatory Guidelines regime. In a USSC survey of federal district judges in 2002, 30-40\% of respondents stated that they believed that the Guidelines avoided unwarranted sentencing disparity only "Sometimes" or "Rarely." In a 2010 USSC survey of federal district judges after Booker, $65 \%$ of respondents indicated that they thought the departure policy statements in the Guidelines Manual were too restrictive.

While below range departures increase for all defendants in the aftermath of Booker, black offenders are significantly less likely to be sentenced below range compared to white defendants. Post Booker, black defendants are $1.6 \%$ less likely to be sentenced below range compared to similar white defendants. These results on below range departures are robust to excluding cases with statutory minimums. ${ }^{18}$

Finally, the last two columns indicate that rates of within range sentencing generally decreased by over $9 \%$ post Booker, but not differentially for black and white offenders. However, conditional on being sentenced within range, black offenders receive a 0.9 month longer sentence compared to their white counterparts post Booker. Recall that prior to Booker, judges were generally not allowed to consider factors such as defendant age, education, physical or mental problems, family, etc. in making sentencing decisions, except for within range sentences. The finding that disparities increase after Booker even for the subset of within range sentences suggests that disparities are not

\footnotetext{
${ }^{18}$ Although not presented here, the differential rates of below range departures are not driven by government sponsored departures, but attributable to judicial departures.
} 
solely driven by the ability of judges to consider various unobservable factors in the aftermath of Booker.

Hispanic defendants face similar increases in disparities in departures from the Guidelines compared to similar white defendants. After Booker, Hispanic defendants are about $0.7 \%$ more likely to be sentenced above range, $1.8 \%$ less likely to be sentenced within range, and conditional on being sentenced within range, receive a 0.3 month longer sentence compared to white defendants. Thus, it appears that the increased racial disparities in sentencing between defendants occurs in the differential application of upward and downward departures, as well as disparate sentence lengths for within range sentences. ${ }^{19}$

\section{VI.C. Robustness Checks for Increasing Racial Disparities}

The previous results identify growing racial disparities in sentence length and departures from the Guidelines after Booker. One may be concerned that the increase in racial disparities after Booker is driven by harsher treatment of other characteristics that are associated with black defendants. For instance, if black defendants disproportionately have lower educational attainment, and judges take a harsher sentencing stance on less educated defendants post Booker, racial disparities may mechanically increase. To account for possible disparities driven by other demographic and crime characteristics, I include full interactions between the Booker indicator and a variety of relevant observables. In column 1 of Table IV, I replicate column 1 from Table II to show the baseline results. In column 2, I account for potential disparities post Booker based on defendant citizenship status, educational attainment, number of dependents, gender and age. In column 3, I account for possible disparities attributable to final offense level and criminal history category. Finally, column 4 also accounts for disparities attributable to offense type.

Note that the significance of the coefficients on Booker interacted with defendant race remained unchanged in all 4 columns and but falls in magnitude. Racial differences in sentencing are not

\footnotetext{
${ }^{19}$ An analysis of other sentence outcomes is presented in Online Appendix Table A5. Black offenders are generally more likely to be incarcerated compared to white offenders, but the differential in incarceration rates does not change post Booker. Probation lengths by defendant race do not change significantly post Booker. However, length of supervised release (served after imprisonment), changes substantially. Black defendants generally receive almost 2 months longer of supervised release, compared to similar white defendants. Post Booker, black and Hispanic defendants receive about 1.5 months less of supervised release compared to white defendants. The divergent changes in racial disparities in sentence length and supervised release length after Booker may be a result of judges replacing actual sentences for supervised release time for black and Hispanic defendants.
} 
the only disparities that emerge after Booker. The results from Table IV reveal growing disparities among defendants of different educational attainments. After Booker, defendants with some college and those with a college degree are sentenced to almost 2 months less, compared to their less educated counterparts. Furthermore, defendants with additional dependents face a slightly lower prison sentence compared to defendants with fewer dependents post Booker. In contrast, disparities do not increase by gender, age or citizenship status.

Fully accounting for disparities due to defendant offense level and criminal history category reveals additional disparities post Booker. The coefficients on offense level interacted with the Booker indicator are omitted because none are statistically significant at the $10 \%$ level, suggesting that judges do not differentially sentence defendants with different offense severity post Booker. However, judges sentence defendants with higher levels of prior criminal activity more harshly post Booker. After Booker, defendants in criminal history categories 2, 3, 4, and 5 face an approximately 1.5 month longer sentence, compared to first time offenders in criminal history category 1. When column 4 includes additional interactions with offense type, none of the coefficients are significant and are thus excluded, suggesting that judges are not sentencing differentially across offenses in the aftermath of Booker.

To further test the robustness of the results, I explore whether increasing racial disparities may be mechanically driven by black defendants being less likely to show remorse for their crimes. I capture this through the court's decision to reduce a defendant's offense level by either two or three points through the acceptance of responsibility provision. I find that lack of remorse as proxied by acceptance of responsibility cannot explain the growing racial disparities in the aftermath of Booker (See Online Appendix Table A6). Overall, these results suggest that racial disparities are robust to differential treatment of defendants by other characteristics in the aftermath of Booker. Despite increasing disparities by educational attainment, family structure, and criminal history, racial disparities persist.

\section{VI.D. How Constraining is Appellate Review? Evidence from Rita, Gall, and Kimbrough}

Booker changed the legal landscape by invalidating the mandatory nature of the Guidelines, but the series of Supreme Court decisions that followed also changed the standard of appellate review. In the first two and half years after Booker, judges were no longer bound to the Guidelines, 
but still faced a high level of appellate scrutiny. Beginning in late 2007, the Rita presumption of reasonableness for within range sentences provided judges with a safe harbor from appellate scrutiny. Gall and Kimbrough removed the presumption of unreasonableness for sentences outside the Guidelines range, further reducing the probability of reversal.

These differential changes in the increase in judicial discretion yield insights into the mechanisms to which judges respond. If judges are greatly bound by the rule-based nature of the Guidelines, one would expect to see large increases in disparities immediately after Booker. If judges are constrained by appellate review, the advisory nature of the Guidelines coupled with strict standards of review may still restrict judicial sentencing. Instead, judges constrained by appellate review would be most free to deviate in the aftermath of Rita, Gall, and Kimbrough.

To capture the dynamics in the aftermath of Booker, I replicate specification (1) using leads and lags in six month intervals for the five years prior and post Booker. These leads and lags are then interacted with defendant race to capture the change in disparities in that specific time period compared to the base period (1994-1999).

Figure II presents the results from a dynamic differences-in-differences specification where the dependent variable is sentence length in months. ${ }^{20}$ Figure II graphs the coefficients for the leads and lags interacted with a black race dummy, along with corresponding 95\% confidence intervals, and shows a clear increasing sentencing gap between black and white defendants. The lack of a significant gap between black and white defendants in the five years prior to Booker suggests that preexisting trends cannot explain growing racial disparities.

Starting about two and a half years after Booker, black defendants appear to face a 2.5 month longer sentence compared to their white counterparts, and the sentencing disparity continues to rise over time. By four years after Booker, the sentencing gap increases to 4.4 months, almost a $10 \%$ increase in the average sentence length. (See Online Appendix Table A7 for results in table format). The fact that racial disparities are not significant in the immediate aftermath of Booker suggests that de novo review may have still been a binding constraint on judicial sentencing, even though the Guidelines were rendered advisory. The appearance of rising racial disparities approximately two and a half years after Booker coincide with Rita, Gall and Kimbrough, indicating that more

\footnotetext{
${ }^{20}$ Although not presented here, results for Hispanic defendants compared to white defendants show a similar, but less pronounced trend.
} 
deferential appellate review greatly affects judicial sentencing behavior.

Figure III captures the pattern in departures from the Guidelines, where the dependent variable is an indicator variable for an above range departure or below range departure. The gap in above range sentencing for black and white defendants appears starting around two and a half years after Booker, persists and grows larger. By five years after the Booker decision, black defendants are over $3.5 \%$ more likely to be sentenced above range compared to their white counterparts. Similarly, the gap in below range sentencing starts around three years after Booker and persists throughout the rest of the period, with black defendants over $5 \%$ less likely to be sentenced below range compared to white defendants four years after Booker. Again, racial disparities in the rate of departures became more pronounced after Rita, Gall and Kimbrough, suggesting that judges are particularly responsive to standards of appellate review. I present evidence in the next section suggesting that the growing racial disparities are also attributable to the increasing number of judges appointed post Booker.

\section{VI.E. Potential Threats to Identification}

There are three primary threats to identification. First, the results may be biased if unobservables that affect sentencing decisions change differentially by defendant race in the wake of Booker. I test for this potential concern by analyzing the extent to which observable offense and defendant characteristics differ in the post Booker period. Black defendants sentenced after Booker are more likely to be male, 0.7 years younger, and less likely to be non U.S. citizens compared to their white counterparts (See Online Appendix Table A8). While these changes are significant, the magnitudes are very small. Moreover, as shown later, younger defendants who are U.S. citizens receive relatively lower sentences compared to otherwise similar, older non U.S. citizens. Thus, any unobservable changes correlated with these demographics would bias downwards the findings. I also find that there is no differential change in criminal history measures by defendant race after Booker. If anything, black defendants have lower base offense levels, Chapter 2 adjusted offense levels and final offense levels after Booker compared to their white counterparts, suggesting that black defendants may commit relatively less severe crimes compared to similar white offenders (See Online Appendix Table A9).

A second threat to identification arises if changes in offense levels are endogenous to Booker 
with no change in "real" offense severity. If judges are less concerned with deflating white defendants' offense levels in order to justify lower sentences, relatively lower offense levels for black defendants compared to white defendants after Booker may mechanically generate the appearance of racial disparities. To address this potential endogeneity, previous researchers have either excluded any control for offense severity or controlled for base offense level, rather than final offense level (Fischman and Schanzenbach 2012). Excluding any measure of offense level as a control is highly problematic given large underlying changes in case composition by race throughout the time period (Starr and Rehavi 2012), but the main results in Table III are highly robust to controlling for base offense level (Online Appendix Table A10). ${ }^{21}$

However, my preferred approach is to test the robustness of my results using a more plausibly exogenous measure of offense severity - the arrest offense. Using data from the U.S. Marshals' Service, the Executive Office of the U.S. Attorneys, the Administrative Office of the U.S. Courts, and the Sentencing Commission, and linking files provided by the Bureau of Justice Statistics, I match federal defendants from the arrest through sentencing stage from 1994-2009. ${ }^{22}$ Through this linked dataset, I obtain for each sentenced offender a highly detailed offense type determined at the time of arrest, exogenous to the sentencing stage. ${ }^{23}$ In column 1 of Online Appendix Table A11, I replicate the main results in Table II on this subset of linkable cases. In column 2 of Table A11, I replicate the results in Table II controlling for arrest offense rather than measures of Guidelines offense level. Table A11 indicates that results are highly robust to controlling for arrest offense, indicating that recent increases in racial disparities are not driven by endogenous offense level determinations.

Finally, a back of the envelope calculation suggests that even pure manipulations in offense levels cannot explain the majority of increases in racial disparities. Table A9 indicates that white offenders' base offense levels increase by approximately 0.2 relative to similar black offenders

\footnotetext{
${ }^{21}$ Furthermore, differential changes in offense levels by race after Booker do not appear across the board. To test whether potential endogeneity in base and final offense levels drive the results, I analyze the subset of sentences which have offense levels that are less likely prone to manipulation because they are relatively low to begin with - those involving offenders in the lowest criminal history category, who represent $50 \%$ of defendants. In results not presented, there is no relative change in base or final offense levels for offenders in the lowest criminal history category and I find large and significant increases in racial disparities after Booker, suggesting that endogenous changes in offense levels without a real change in offense severity are unlikely to fully explain the increase in racial disparities.

${ }^{22}$ Descriptions of the data and linking files can be found at http://www.icpsr.umich.edu/icpsrweb/content/NACJD/guides/fjsp.html.

${ }^{23}$ The linked dataset does not provide a separate race category for Hispanic defendants, so results using this dataset compare white and black defendants.
} 
after Booker. In the dataset, a one point increase in base offense level is associated with an average 3 month increase in sentence length. Thus, even assuming that base offense levels are changing without any corresponding changes in "real" offense severity, only a racial disparity of 0.6 months can be explained by this mechanical artifact, less than $30 \%$ of the increase in racial disparity following Booker.

A third potential threat to the identification is if Booker is associated with changes in selection in the types of defendants that reach the sentencing stage. For instance, if prosecutors disproportionately drop or dismiss charges against marginal black defendants, the remaining black defendants at the sentencing stage might receive longer sentences compared to similar white offenders. To address potential changes in selection prior to the sentencing stage, I test the likelihood of guilty pleas, dropped charges, and deferred prosecutions against black defendants compared to similar white defendants after Booker using data on all federal arrests and bookings from 19942009. ${ }^{24}$ Online Appendix Table A12 suggests no significant changes in the rates at which black defendants plead guilty, or the likelihood of dropped charges or deferred prosecution, suggesting no significant changes in selection prior to sentencing. ${ }^{25}$

\section{VI.F. Free at Last? Effects of Judicial Sentencing Philosophies and Experience}

While disparities in sentencing outcomes increased in the wake of Booker, the response to increased judicial discretion may differ by judge sentencing philosophies and experience. In particular, judges appointed before Booker may sentence differently compared to judges appointed after Booker. Judges with substantial experience sentencing under the mandatory Guidelines regime may become acculturated to the Guidelines, and less likely to change their sentencing practices in the aftermath of Booker.

Since Booker, there have been 190 confirmed judicial appointments to US district courts, 93 new judges up to the end of the fiscal sentencing year 2009. ${ }^{26}$ The judges appointed prior to 2009 were appointed by President George W. Bush, and the remaining judges by President Barack

\footnotetext{
${ }^{24}$ Data is obtained from the Federal Justice Statistics Program: Arrests and Bookings for Federal Offenses, which covers all offenders within the custody of the United Marshals Service.

${ }^{25} \mathrm{~A}$ deferred prosecution occurs when a prosecutor agrees to not file charges in exchange for the defendant taking specified actions, such as payment of fines, and continued cooperation during investigation.

${ }^{26}$ Nine judges were commissioned in 2005, 26 commissioned in 2006, 32 in 2007, and 26 in 2008. Post Booker appointed judges are now active in 53 district courts, some comprising up to $75 \%$ of the active bench within a court.
} 
Obama. However, all Obama appointees began active service following the end of the fiscal year 2009, so this paper cannot identify the sentencing patterns of new Democratic appointed judges. Within the matched data from 2000-2009, post Booker appointed judges have sentenced a growing share of criminal defendants, to almost $10 \%$ of cases in fiscal year 2009.

Recall that random assignment of cases to judges is necessary in order to compare sentencing practices of judges within a district court. According to the Administrative Office of the United States Courts, "[t]he majority of courts use some variation of a random drawing" as prescribed by local court orders. However, random assignment may be violated in some instances. For example, senior status judges with reduced caseloads may select the type of cases they hear during the year, and some courts assign certain types of cases to particular judges.

To exclude senior status judges who may not obtain cases through a random assignment process, I drop judges who were formally retired prior to 2000, and judges and district courthouses with annual caseloads of less than 25 cases. To ensure that I only include courthouses with random assignment of cases, I then test for random assignment by district courthouse using the matched USSC, TRAC, and Federal Judicial Center data from 2000-2009, for a set of five predetermined defendant characteristics: gender, age, a black race indicator, number of dependents, and an indicator for less than a high school degree. For each of the five defendant characteristics, I regress the characteristic on district courthouse by sentencing year fixed effects, sentencing month fixed effects and judge fixed effects. I test the hypothesis of no judge effects (the null hypothesis) using an F-test for whether the judge fixed effects are equal to zero using seemingly unrelated regression (SUR) following Autor and Houseman (2010). P-values for these tests by district courthouse are presented in Online Appendix Table A13. I drop all courthouses with F-test p-values less than 0.05 , but results are robust to other cutoffs. The subsample of district courts with random case assignment includes 72 courts representing about $50 \%$ of the cases from 2000-2009. ${ }^{27}$

Table V presents the results, using this subsample of district courts, of specification (2) with an interaction between defendant race, the Booker indicator, and an indicator variable equal to one for judges appointed post Booker, in addition to the interaction between defendant race and the Booker indicator. ${ }^{28}$ The triple interaction terms measures the different sentencing practices of post Booker

\footnotetext{
${ }^{27}$ Online Appendix Table A14 presents the results of the core specification from Table II using the random sample and full matched sample.

${ }^{28}$ Note that because all "new" judges were appointed after Booker, in this instance, the triple interaction is identical
} 
appointed judges on disparities in sentencing, compared to pre Booker judges in the aftermath of Booker. Column 1 presents results for sentence length. The coefficients of the Booker indicator interacted with defendant race indicate that racial disparities increase by 1.7 months between black and white defendants after Booker, but particularly for post Booker appointed judges. These "new" judges sentence black defendants to an additional 5.4 months in prison compared to similar white defendants, relative to their colleagues.

Column 2 indicates that all judges are associated with greater rates of above range departures for black defendants compared to white defendants. Column 4 also indicates different rates of below range departures for black and white defendants after Booker for all judges. As shown in column 7, conditional on within range sentencing, all judges sentence black defendants to about 0.6 months longer in prison and Hispanic defendants 0.3 months longer in prison compared to white defendants. However, the black-white sentence gap for within range sentences is 1.2 months larger for post Booker judges compared to pre Booker appointed judges. Similarly, the Hispanic-white sentence gap for within range sentences is 0.8 months larger for post Booker judges compared to their pre Booker colleagues.

These results indicate that post Booker appointed judges exhibit greater racial disparities in their sentencing patterns than their pre Booker colleagues, even within the same district courthouse. $^{29}$ Given that cases are randomly assigned within a district, it is unlikely that these post Booker judges were assigned cases in which black defendants deserved longer sentences compared to their observably similar white counterparts. ${ }^{30}$ Furthermore, these results are not driven by prosecutors being more likely to charge mandatory minimums that trump the minimum Guidelines sentence when a case is assigned to a post Booker appointed judge. ${ }^{31}$ Online Appendix Table A16 reveals that post Booker judicial appointees exhibit greater racial disparities than their colleagues even among cases in which no mandatory minimum was charged or where the mandatory minimum was less than the applicable Guidelines minimum. The black-white sentence gap for within range sentences is 1.5 months larger for post Booker judges compared to pre Booker appointed

\footnotetext{
to an interaction between defendant race and "new" judge.

${ }^{29}$ Results are robust to using the full matched sample. See Online Appendix Table A15.

${ }^{30}$ In results not presented, there are no differences in base or final offense levels between post Booker judges and pre Booker judges, indicating no differential fact-finding.

${ }^{31}$ In results not presented, there is no difference in the rate of mandatory minimums, or rate of binding mandatory minimums, between post Booker judges and pre Booker judges.
} 
judges.

Moreover, greater racial disparities among post Booker appointed judges cannot be explained by the fact that these judges were appointed by George W. Bush. In Online Appendix Table A17, I include all interactions between defendant race, the Booker dummy variable, and an indicator variable for pre Booker Bush appointees. These controls allow me to compare the sentencing patterns of post Booker judges to their pre Booker appointed counterparts. The coefficient on Pre Booker Bush Judge indicates that pre Booker Bush appointees were generally 4\% less likely to sentence below range for all defendants compared to their colleagues, but with no changes in sentencing practices in the aftermath of Booker. Table A17 also indicates that the coefficients on Post Booker Judge and its interactions with defendant race remained unchanged from those presented in Table V, confirming that the sentencing patterns of post Booker appointed judges are not attributable to the fact that these judges are George W. Bush appointees.

Furthermore, new judges in earlier cohorts also do not sentence differently from their more experienced colleagues, either before or after Booker. In Online Appendix Table A18, I present main results including all interactions between defendant race, Booker, and an indicator for new judges appointed between 2000-2004. Table A18 indicates that judge experience alone cannot explain inter-judge differences in sentencing, suggesting that the results are not driven by a "new" judge effect. Instead, the results suggest that exposure to sentencing under a mandatory Guidelines regime may drive the differential sentencing patterns between pre and post Booker appointed judges.

Different sentencing philosophies and practices between judges may not only be driven by experience under a mandatory Guidelines regime, but other personal preferences. To proxy for sentencing philosophies, I replicate the regressions in Table V with additional controls for judge gender, race, political affiliation, and an indicator for whether the judge was appointed prior to the adoption of the Guidelines. Online Appendix Table A19 shows that post Booker appointed judges are still the main source of increasing racial disparities. However, other judicial demographic characteristics are also associated with certain sentencing patterns. Table A19 shows that female judges sentence all defendants to 2.4 months less in prison after Booker compared to their male colleagues. Table A19 also suggests that black judges were about $6 \%$ less likely to sentence defendants of other races below range prior to Booker, but reversed this practice in the aftermath 
of Booker. Also striking are the different sentencing practices of Democratic and Republican appointed judges. Democratic judges are $2.1 \%$ more likely than Republican judges to depart downwards from the Guidelines, and even conditional on sentencing within range, issue a sentence to all defendants that is 0.4 months less compared to their Republican colleagues.

\section{VI.G. Response of Prosecutors to Increased Judicial Discretion}

While the disparities estimated in this paper do not capture the compounded disparities that can result at each stage of the criminal process, I conclude by exploring the impact of increased judicial discretion on changes in prosecutorial decisions to charge mandatory minimums. Given that Booker left Congressionally-enacted statutory minimums intact, one would not necessarily expect judicial treatment of mandatory minimums to change in the aftermath of Booker. However, prosecutors may strategically respond to increased judicial discretion post Booker if they want to bind judges from departing downwards. After Booker, prosecutors have commented that they are far less willing to forego charging mandatory minimums because judges ultimately sentence defendants below the Guidelines minimum.

Table VI presents results suggesting that prosecutorial discretion post Booker has not differentially affected black and white defendants in terms of charging offenses that carry mandatory minimums, although black and Hispanic defendants are far more likely to receive a mandatory minimum. ${ }^{32}$ However, black defendants are significantly more likely to face a binding mandatory minimum post Booker compared to white defendants. ${ }^{33}$ The greater prevalence of binding mandatory minimums for black defendants in the aftermath of Booker suggests that more statutory minimums are applied to black defendants which exceed the Guidelines recommended sentences compared to similar white offenders. This finding suggests that black defendants may face statutory minimums that are harsher than the severity of the crime dictates, potentially indicating prosecutorial disparities post Booker. See Figure IV for graphical evidence of the change in the rate of statutory minimums, and the rate of binding statutory minimums after Booker.

However, conditional on being convicted of a charge that carries a mandatory minimum, deci-

\footnotetext{
${ }^{32}$ These findings are somewhat consistent with those of Starr and Rehavi (2012) who use a regression discontinuity design and find a temporary increase in mandatory minimums for black defendants charged immediately after Booker, but no differential long-term change between black and white defendants after Booker.

${ }^{33}$ This finding is robust to looking only at drug statutory minimums (the majority of statutory minimums cases) and controlling for specific drug type.
} 
sions to reduce sentences below the mandatory minimum do not differ significantly by defendant race after Booker. A judge has some leeway in reducing sentence length for certain drug trafficking offenses under the "safety valve" provision under 18 U.S.C. $§ 3553(f)$, which allows a judge to reduce the punishment for low level, first time offenders. Prosecutors also have the ability to reduce sentences below the mandatory minimum if the defendant offers "substantial assistance" during another investigation or prosecution under 18 U.S.C. $33553(\mathrm{e})$.

Column 3 suggest that the application of the safety valve does not change differentially post Booker, although black defendants are significantly less likely to receive the safety valve compared to similar white offenders for drug trafficking crimes. ${ }^{34}$ Similarly, column 4 indicates that government sponsored substantial assistance motions for cases with mandatory minimums do not change differentially between offenders post Booker, although non white defendants are generally significantly less likely to receive substantial assistance motions.

While prosecutorial charging decisions likely contribute to increasing racial disparities post Booker, judicially-induced disparities remain. Following Fischman and Schanzenbach (2012), I replicate the main results from Table III for the subset of cases in which mandatory minimums are relatively less likely to apply and bind - offenders in the lowest criminal history category, in crimes not involving a firearm. Column 1 of Table VII indicates that racial disparities increased after Booker in this subset of cases, which are less subject to prosecutorial discretion. These results indicate that prosecutorial charging is unlikely capable of fully explaining recent increases in racial disparities.

\section{Conclusion}

After almost two decades of mandatory Guidelines sentencing, the Supreme Court struck down the Guidelines in United States v. Booker, greatly increasing the degree of judicial discretion. In subsequent decisions, the Court further increased judicial discretion by reducing the degree of appellate review and granting judges explicit permission to reject the policies of the Sentencing Commission.

Using comprehensive data on federal defendants sentenced from 1994-2009, I find evidence

\footnotetext{
${ }^{34}$ This finding is also reported in the Sentencing Commission Report (2011) which states that in recent years, white defendants in drug cases are more frequently granted the safety valve exception compared to other defendants.
} 
that increased judicial discretion via Booker has led to large and robust increases in racial disparities in sentencing, particularly after periods of reduced appellate scrutiny. By four years after Booker, the racial sentencing gap increases to 4.4 months, almost a $10 \%$ increase in the average sentence length. I also find that recent increases in racial disparities in sentencing appear to be larger among judges appointed post Booker, consistent with a story in which judges experienced with sentencing under rule-based sentencing continue to follow the Guidelines even when given more discretion. These findings should, however, be interpreted cautiously as they only apply to new George W. Bush appointees. Barack Obama appointed judges may exhibit different sentencing patterns. Finally, my results suggest that prosecutors charge black defendants with higher rates of binding mandatory minimums compared to white defendants after Booker, consistent with prosecutors attempting to bind judges to prevent them from departing downwards from the Guidelines in response to increased judicial discretion.

Despite the increase in racial disparities in federal sentencing after Booker, $75 \%$ of federal district judges believe that the current advisory regime better achieves the purposes of sentencing compared to the mandatory Guidelines regime prior to Booker (3\%) or the "free at last" regime before the implementation of the Guidelines (8\%). Only $14 \%$ of judges believe that a new mandatory Guidelines regime that complies with the Sixth Amendment would best achieve sentencing goals.

The findings in this paper suggest that while most federal district judges prefer the expanded judicial discretion under the current advisory system to the mandatory Guidelines regime, discretion comes with potentially undesirable consequences. An increase in disparities in the wake of increased judicial discretion can reflect unwarranted disparities if judicial bias enters into decisionmaking. On the other hand, disparities may be warranted if expanded discretion allows judges to tailor a sentence to the unique circumstances of an offender. For instance, disparities may emerge if judges are sentencing according to defendant characteristics, both observed and unobserved, that are correlated with actual recidivism risk.

In fact, recidivism rates are higher among nonwhite offenders, offenders with more extensive criminal histories and lower educational attainment, and I find that judges sentence these defendants to longer prison terms after Booker. Unconditional on other characteristics, black offenders are more likely to recidivate $(32.8 \%)$ than Hispanic offenders $(24.3 \%)$ and white offenders $(16.0 \%)$ 
(United States Sentencing Commission 2004). Even controlling for basic demographics, criminal history and severity of offense, blacks are about 3.2 percentage points more likely to recidivate than white offenders (Kuziemko 2013). Taken with Kuziemko's finding that an additional month of time served reduces three-year recidivism by 1.3 percentage points, a judge would sentence black defendants to an additional 2.4 months in prison to equalize the recidivism rate across observably similar black and white defendants. This magnitude is consistent with the size of racial disparities I find in the aftermath of Booker, suggesting that increased disparities may be somewhat attributable to socially optimal sentencing aimed at reducing recidivism.

On the other hand, recidivism also varies greatly by gender and age after controlling for various observables, and judges are unresponsive to these variables in the aftermath of Booker, indicating that judges are not solely sentencing based on actual recidivism risk. Future work could analyze the extent to which disparities in sentencing are warranted by looking at rates of recidivism in the federal criminal justice system. More generally, the framework in this paper can be applied to analyzing the impact of increased discretion on many other actors in the criminal justice system. Further work on the interactions of actors at various stages in the criminal process is critical to a thorough exploration of disparities in the federal criminal justice system. 
APPENDIX

Table A1. Guidelines Sentencing Chart

\begin{tabular}{|c|c|c|c|c|c|c|c|}
\hline & \multirow[b]{2}{*}{$\begin{array}{c}\text { Offense } \\
\text { Level }\end{array}$} & \multicolumn{6}{|c|}{ Criminal History Category (Criminal History Points) } \\
\hline & & $\begin{array}{c}I \\
(0 \text { or } 1) \\
\end{array}$ & $\begin{array}{c}\text { II } \\
(2 \text { or } 3) \\
\end{array}$ & $\begin{array}{c}\text { III } \\
(4,5,6) \\
\end{array}$ & $\begin{array}{c}\text { IV } \\
(7,8,9)\end{array}$ & $\begin{array}{c}V \\
(10,11,12)\end{array}$ & $\begin{array}{c}\text { VI } \\
\text { (13 or more) }\end{array}$ \\
\hline & $\begin{array}{l}1 \\
2 \\
3\end{array}$ & $\begin{array}{l}0-6 \\
0-6 \\
0-6\end{array}$ & $\begin{array}{l}0-6 \\
0-6 \\
0-6\end{array}$ & $\begin{array}{l}0-6 \\
0-6 \\
0-6\end{array}$ & $\begin{array}{l}0-6 \\
0-6 \\
0-6 \\
\end{array}$ & $\begin{array}{l}0-6 \\
0-6 \\
2-8\end{array}$ & $\begin{array}{l}0-6 \\
1-7 \\
3-9\end{array}$ \\
\hline Zone A & $\begin{array}{l}4 \\
5 \\
6\end{array}$ & $\begin{array}{l}0-6 \\
0-6 \\
0-6\end{array}$ & $\begin{array}{l}0-6 \\
0-6 \\
1-7\end{array}$ & $\begin{array}{l}0-6 \\
1-7 \\
2-8\end{array}$ & $\begin{array}{l}2-8 \\
4-10 \\
6-12\end{array}$ & $\begin{array}{r}4-10 \\
6-12 \\
9-15 \\
\end{array}$ & $\begin{array}{r}6-12 \\
9-15 \\
12-18 \\
\end{array}$ \\
\hline & $\begin{array}{l}7 \\
8 \\
9\end{array}$ & $\begin{array}{c}0-6 \\
0-6 \\
4-10\end{array}$ & $\begin{array}{l}2-8 \\
4-10 \\
6-12\end{array}$ & $\begin{array}{l}4-10 \\
6-12 \\
8-14 \\
\end{array}$ & $\begin{array}{c}8-14 \\
10-16 \\
12-18\end{array}$ & $\begin{array}{l}12-18 \\
15-21 \\
18-24\end{array}$ & $\begin{array}{l}15-21 \\
18-24 \\
21-27\end{array}$ \\
\hline Zone C & $\begin{array}{l}10 \\
11 \\
12\end{array}$ & $\begin{array}{l}6-12 \\
8-14 \\
10-16\end{array}$ & $\begin{array}{c}8-14 \\
10-16 \\
12-18 \\
\end{array}$ & $\begin{array}{l}10-16 \\
12-18 \\
15-21\end{array}$ & $\begin{array}{l}15-21 \\
18-24 \\
21-27\end{array}$ & $\begin{array}{l}21-27 \\
24-30 \\
27-33\end{array}$ & $\begin{array}{l}24-30 \\
27-33 \\
30-37\end{array}$ \\
\hline & $\begin{array}{l}13 \\
14 \\
15\end{array}$ & $\begin{array}{l}\frac{12-18}{15-21} \\
18-24\end{array}$ & $\begin{array}{l}15-21 \\
18-24 \\
21-27\end{array}$ & $\begin{array}{l}18-24 \\
21-27 \\
24-30\end{array}$ & $\begin{array}{l}24-30 \\
27-33 \\
30-37\end{array}$ & $\begin{array}{l}30-37 \\
33-41 \\
37-46\end{array}$ & $\begin{array}{l}33-41 \\
37-46 \\
41-51\end{array}$ \\
\hline & $\begin{array}{l}16 \\
17 \\
18\end{array}$ & $\begin{array}{l}21-27 \\
24-30 \\
27-33\end{array}$ & $\begin{array}{l}24-30 \\
27-33 \\
30-37\end{array}$ & $\begin{array}{l}27-33 \\
30-37 \\
33-41\end{array}$ & $\begin{array}{l}33-41 \\
37-46 \\
41-51\end{array}$ & $\begin{array}{l}41-51 \\
46-57 \\
51-63\end{array}$ & $\begin{array}{l}46-57 \\
51-63 \\
57-71\end{array}$ \\
\hline & $\begin{array}{l}19 \\
20 \\
21\end{array}$ & $\begin{array}{l}30-37 \\
33-41 \\
37-46\end{array}$ & $\begin{array}{l}33-41 \\
37-46 \\
41-51\end{array}$ & $\begin{array}{l}37-46 \\
41-51 \\
46-57\end{array}$ & $\begin{array}{l}46-57 \\
51-63 \\
57-71\end{array}$ & $\begin{array}{l}57-71 \\
63-78 \\
70-87\end{array}$ & $\begin{array}{l}63-78 \\
70-87 \\
77-96\end{array}$ \\
\hline & $\begin{array}{l}22 \\
23 \\
24\end{array}$ & $\begin{array}{l}41-51 \\
46-57 \\
51-63\end{array}$ & $\begin{array}{l}46-57 \\
51-63 \\
57-71\end{array}$ & $\begin{array}{l}51-63 \\
57-71 \\
63-78\end{array}$ & $\begin{array}{l}63-78 \\
70-87 \\
77-96\end{array}$ & $\begin{array}{c}77-96 \\
84-105 \\
92-115\end{array}$ & $\begin{array}{c}84-105 \\
92-115 \\
100-125\end{array}$ \\
\hline Zane D & $\begin{array}{l}25 \\
26 \\
27\end{array}$ & $\begin{array}{l}57-71 \\
63-78 \\
70-87\end{array}$ & $\begin{array}{l}63-78 \\
70-87 \\
78-97\end{array}$ & $\begin{array}{c}70-87 \\
78-97 \\
87-108\end{array}$ & $\begin{array}{c}84-105 \\
92-115 \\
100-125\end{array}$ & $\begin{array}{l}100-125 \\
110-137 \\
120-150\end{array}$ & $\begin{array}{l}110-137 \\
120-150 \\
130-162\end{array}$ \\
\hline 2006 & $\begin{array}{l}28 \\
29 \\
30\end{array}$ & $\begin{array}{l}78-97 \\
87-108 \\
97-121\end{array}$ & $\begin{array}{c}87-108 \\
97-121 \\
108-135\end{array}$ & $\begin{array}{c}97-121 \\
108-135 \\
121-151\end{array}$ & $\begin{array}{l}110-137 \\
121-151 \\
135-168\end{array}$ & $\begin{array}{l}130-162 \\
140-175 \\
151-188\end{array}$ & $\begin{array}{l}140-175 \\
151-188 \\
168-210\end{array}$ \\
\hline & $\begin{array}{l}31 \\
32 \\
33\end{array}$ & $\begin{array}{l}108-135 \\
121-151 \\
135-168\end{array}$ & $\begin{array}{l}121-151 \\
135-168 \\
151-188\end{array}$ & $\begin{array}{l}135-168 \\
151-188 \\
168-210\end{array}$ & $\begin{array}{l}151-188 \\
168-210 \\
188-235\end{array}$ & $\begin{array}{l}168-210 \\
188-235 \\
210-262\end{array}$ & $\begin{array}{l}188-235 \\
210-262 \\
235-293\end{array}$ \\
\hline & $\begin{array}{l}34 \\
35 \\
36\end{array}$ & $\begin{array}{l}151-188 \\
168-210 \\
188-235\end{array}$ & $\begin{array}{l}168-210 \\
188-235 \\
210-262\end{array}$ & $\begin{array}{l}188-235 \\
210-262 \\
235-293\end{array}$ & $\begin{array}{l}210-262 \\
235-293 \\
262-327\end{array}$ & $\begin{array}{l}235-293 \\
262-327 \\
292-365\end{array}$ & $\begin{array}{l}262-327 \\
292-365 \\
324-405\end{array}$ \\
\hline & $\begin{array}{l}37 \\
38 \\
39\end{array}$ & $\begin{array}{l}210-262 \\
235-293 \\
262-327\end{array}$ & $\begin{array}{l}235-293 \\
262-327 \\
292-365\end{array}$ & $\begin{array}{l}262-327 \\
292-365 \\
324-405\end{array}$ & $\begin{array}{l}292-365 \\
324-405 \\
360-\text { life }\end{array}$ & $\begin{array}{l}324-405 \\
360-\text {-life } \\
360 \text {-life }\end{array}$ & $\begin{array}{l}\text { 360-life } \\
360 \text {-life } \\
360 \text {-life }\end{array}$ \\
\hline & $\begin{array}{l}40 \\
41 \\
42\end{array}$ & $\begin{array}{l}292-365 \\
324-405 \\
360-\text { life }\end{array}$ & $\begin{array}{l}324-405 \\
360-\text { life } \\
360 \text {-life }\end{array}$ & $\begin{array}{l}\text { 360-life } \\
360 \text {-life } \\
\text { 360-life }\end{array}$ & $\begin{array}{l}\text { 360-life } \\
\text { 360-life } \\
\text { 360-life }\end{array}$ & $\begin{array}{l}\text { 360-life } \\
360-\text {-life } \\
360 \text {-life }\end{array}$ & $\begin{array}{l}360 \text {-life } \\
360-\text {-life } \\
360 \text {-life }\end{array}$ \\
\hline & 43 & life & life & life & life & life & life \\
\hline
\end{tabular}

Notes: Recommended sentence lengths in months. 
Table A2. Sentence Length in Months - Robustness Checks

\begin{tabular}{|c|c|c|c|c|c|}
\hline & $\overline{(1)}$ & 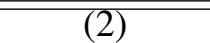 & (3) & (4) & $\overline{(5)}$ \\
\hline & Sentence & Sentence & Sentence & Sentence & Sentence \\
\hline Booker*Black & $2.311 * * *$ & $2.514 * * *$ & $1.355 * * *$ & $2.588 * * *$ & $2.340 * * *$ \\
\hline & $(0.683)$ & $(0.575)$ & $(0.309)$ & $(0.658)$ & $(0.595)$ \\
\hline Booker*Hispanic & $1.466 * * *$ & $1.830 * * *$ & $1.695 * * *$ & $1.681 * * *$ & $1.673 * * *$ \\
\hline & $(0.487)$ & $(0.450)$ & $(0.356)$ & $(0.466)$ & $(0.449)$ \\
\hline Booker*Other & 1.848 & 1.491 & $2.249 * * *$ & $2.927 * *$ & $2.646 * * *$ \\
\hline Black & $\begin{array}{l}(1.149) \\
2.885 * * *\end{array}$ & $\begin{array}{l}(0.932) \\
3.555 * * *\end{array}$ & $\begin{array}{c}(0.735) \\
0.577 * * *\end{array}$ & $\begin{array}{l}(1.137) \\
4.501 * * *\end{array}$ & $\begin{array}{c}(0.983) \\
2.680 * * *\end{array}$ \\
\hline & $(0.422)$ & $(0.344)$ & $(0.190)$ & $(0.474)$ & $(0.361)$ \\
\hline Hispanic & $\begin{array}{l}0.862^{*} \\
(0.478)\end{array}$ & $\begin{array}{c}1.596 * * * \\
(0.410)\end{array}$ & $\begin{array}{r}-0.0824 \\
(0.267)\end{array}$ & $\begin{array}{c}0.829 \\
(0.530)\end{array}$ & $\begin{array}{l}0.863^{*} \\
(0.455)\end{array}$ \\
\hline Other & $\begin{array}{c}1.781 \\
(1.200)\end{array}$ & $\begin{array}{l}1.140 \\
(1.036)\end{array}$ & $\begin{array}{c}0.474 \\
(0.591)\end{array}$ & $\begin{array}{c}2.909 * * * \\
(1.022)\end{array}$ & $\begin{array}{c}1.079 \\
(1.090)\end{array}$ \\
\hline Booker & $\begin{array}{c}-2.939 * * * \\
(1.069)\end{array}$ & $\begin{array}{c}-3.232 * * * \\
(0.991)\end{array}$ & $\begin{array}{c}-2.126 * * * \\
(0.709)\end{array}$ & $\begin{array}{l}-1.340 \\
(1.206)\end{array}$ & $\begin{array}{c}-3.103 * * * \\
(1.015)\end{array}$ \\
\hline Non US Citizen & $\begin{array}{c}1.366^{* * * *} \\
(0.495)\end{array}$ & $\begin{array}{c}1.584 * * * \\
(0.454)\end{array}$ & $\begin{array}{c}0.364 \\
(0.304)\end{array}$ & $\begin{array}{c}-0.176 \\
(0.557)\end{array}$ & $\begin{array}{c}1.445 * * * \\
(0.449)\end{array}$ \\
\hline HS Grad & $\begin{array}{l}-0.369 \\
(0.236)\end{array}$ & $\begin{array}{c}-0.526 * * * * \\
(0.182)\end{array}$ & $\begin{array}{c}-0.225^{* *} \\
(0.0877)\end{array}$ & $\begin{array}{c}-0.0568 \\
(0.240)\end{array}$ & $\begin{array}{c}-0.554 * * * \\
(0.182)\end{array}$ \\
\hline Some College & $\begin{array}{c}-1.523 * * * \\
(0.285)\end{array}$ & $\begin{array}{c}-1.790 * * * \\
(0.176)\end{array}$ & $-0.752 * * * *$ & $\begin{array}{c}-0.644 * * \\
(0.301)\end{array}$ & $-1.624 * * *$ \\
\hline College Grad & $\begin{array}{c}-2.222 * * * \\
(0.489)\end{array}$ & $\begin{array}{c}-2.742 * * * \\
(0.225)\end{array}$ & $\begin{array}{c}-1.010 * * * \\
(0.175)\end{array}$ & $\begin{array}{c}0.335 \\
(0.355)\end{array}$ & $\begin{array}{c}-1.882 * * * \\
(0.235)\end{array}$ \\
\hline \# Dependents & $\begin{array}{l}-0.123 \\
(0.136)\end{array}$ & $\begin{array}{c}-0.149 * * * * \\
(0.0450)\end{array}$ & $\begin{array}{c}-0.110^{* * * *} \\
(0.0252)\end{array}$ & $\begin{array}{c}-0.106^{*} \\
(0.0598)\end{array}$ & $\begin{array}{c}-0.140 * * * \\
(0.0439)\end{array}$ \\
\hline Female & $\begin{array}{c}-5.347 * * * \\
(0.595)\end{array}$ & $\begin{array}{c}-5.502 * * * * \\
(0.458)\end{array}$ & $\begin{array}{c}-2.633^{* * * *} \\
(0.223)\end{array}$ & $\begin{array}{c}-7.139 * * * * \\
(0.656)\end{array}$ & $\begin{array}{c}-5.416^{* * * *} \\
(0.498)\end{array}$ \\
\hline Age & $\begin{array}{l}0.134 * * \\
(0.0622)\end{array}$ & $\begin{array}{c}0.168 * * * \\
(0.0394)\end{array}$ & $\begin{array}{c}0.255^{* * * *} \\
(0.0255)\end{array}$ & $\begin{array}{c}0.328 * * * \\
(0.0647)\end{array}$ & $\begin{array}{c}0.138 * * * \\
(0.0377)\end{array}$ \\
\hline $\mathrm{Age}^{2}$ & $\begin{array}{c}-0.00125 \\
(0.000757)\end{array}$ & $\begin{array}{c}-0.00192 * * * \\
(0.000443)\end{array}$ & $\begin{array}{c}-0.00267 * * * \\
(0.000304)\end{array}$ & $\begin{array}{c}-0.00216 * * * \\
(0.000674)\end{array}$ & $\begin{array}{c}-0.00139 * * * \\
(0.000423)\end{array}$ \\
\hline Mandatory Min & $\begin{array}{c}23.89 * * * \\
(1.994)\end{array}$ & & & $\begin{array}{c}34.25 * * * \\
(2.135)\end{array}$ & $\begin{array}{c}22.92 * * * \\
(1.773)\end{array}$ \\
\hline Mandatory Min Length & & $\begin{array}{c}0.00609 * * * \\
(0.00135)\end{array}$ & & & \\
\hline Observations & 552,524 & 679,159 & 440,930 & 455,203 & 678,960 \\
\hline R-squared & 0.650 & 0.732 & 0.771 & 0.642 & 0.741 \\
\hline
\end{tabular}

Notes: Data is from the USSC from 1994-2009. Column 1 presents results for all sentences including life sentences top coded at 470 months. Column 2 presents results controlling for mandatory minimum length. Column 3 presents results excluding sentences with statutory mandatory minimums. Column 4 presents results controlling for Chapter 2 adjusted offense level, which is only available for years 1999-2009. Column 5 presents results controlling for armed career criminal and career offender classification. All regressions contain controls for offense type, and dummies for each offense level and criminal history combination. Regressions also contain district by sentencing year, and sentencing month fixed effects, and standard errors are clustered at the district level. Race trends are excluded. $* * *=$ significant at 1 percent level, $* *=$ significant at 5 percent level, $*$ = significant at 10 percent level. 
Table A3. Sentence Length in Months - Placebo Test

\begin{tabular}{|c|c|c|c|c|c|c|c|c|c|c|}
\hline & $\overline{(1)}$ & $\overline{(2)}$ & $\overline{(3)}$ & $\overline{(4)}$ & $\overline{(5)}$ & $\overline{(6)}$ & $\overline{(7)}$ & $\overline{(8)}$ & $\overline{(9)}$ & $(10)$ \\
\hline & Sentence & Sentence & Sentence & Sentence & Sentence & Sentence & Sentence & Sentence & Sentence & Sentence \\
\hline Placebo Case & 1995 & 1996 & 1997 & 1998 & 1999 & 2000 & 2001 & 2002 & 2003 & 2004 \\
\hline \multirow[t]{2}{*}{ Placebo*Black } & $-2.545 * *$ & $-2.924 * * *$ & $-2.429 * *$ & $-1.743 * *$ & $-1.907 * * *$ & -0.961 & -0.959 & 0.0188 & 0.672 & 0.867 \\
\hline & $(1.080)$ & $(0.921)$ & $(0.928)$ & $(0.787)$ & $(0.709)$ & $(0.642)$ & $(0.649)$ & $(0.804)$ & $(0.780)$ & $(0.739)$ \\
\hline \multirow[t]{2}{*}{ Placebo*Hispanic } & $-2.373 * *$ & $-1.758 *$ & -0.845 & -0.355 & -0.838 & -0.461 & -0.653 & -0.316 & -0.415 & 0.688 \\
\hline & $(0.975)$ & $(0.941)$ & $(0.738)$ & $(0.705)$ & $(0.602)$ & $(0.602)$ & $(0.675)$ & $(0.691)$ & $(0.658)$ & $(0.559)$ \\
\hline \multirow[t]{2}{*}{ Placebo*Other } & -0.854 & -1.739 & -0.504 & 0.470 & 0.549 & 1.735 & 0.929 & -0.00518 & -0.878 & 0.261 \\
\hline & $(2.510)$ & (1.919) & $(1.899)$ & $(1.969)$ & $(1.623)$ & $(1.196)$ & $(1.826)$ & $(1.974)$ & (1.876) & (1.464) \\
\hline Race Trends? & Yes & Yes & Yes & Yes & Yes & Yes & Yes & Yes & Yes & Yes \\
\hline Observations & 692,039 & 692,039 & 692,039 & 692,039 & 692,039 & 692,039 & 692,039 & 692,039 & 692,039 & 692,039 \\
\hline R-squared & 0.741 & 0.741 & 0.741 & 0.741 & 0.741 & 0.741 & 0.741 & 0.741 & 0.741 & 0.741 \\
\hline
\end{tabular}

Notes: Data is from the USSC from 1994-2009. Coefficients are from DD regressions of placebo case decisions on racial disparities in sentencing, identical to specification (4) in Table II. All regressions contain controls for offense type, and dummies for each offense level and criminal history combination. Regressions also contain district by sentencing year, and sentencing month fixed effects, and standard errors are clustered at the district level. Race trends are included. $* * *=$ significant at 1 percent level, $* *=$ significant at 5 percent level, $*=$ significant at 10 percent level. 
Table A4. Sentence Lengths by Major Offense Categories

\begin{tabular}{lccccccc}
\hline \hline & $\begin{array}{c}(1) \\
\text { Drugs }\end{array}$ & $\begin{array}{c}(2) \\
\text { Immigration }\end{array}$ & $\begin{array}{c}(3) \\
\text { Firearms }\end{array}$ & $\begin{array}{c}(4) \\
\text { Fraud }\end{array}$ & $\begin{array}{c}(5) \\
\text { Bank } \\
\text { Robbery }\end{array}$ & $\begin{array}{c}(6) \\
\text { Larceny }\end{array}$ & $\begin{array}{c}(7) \\
\text { Forgery }\end{array}$ \\
\hline Booker*Black & $2.354^{* * *}$ & 0.0632 & 0.475 & $1.487 * * *$ & -2.248 & 0.379 & 0.278 \\
Booker*Hispanic & $(0.804)$ & $(0.473)$ & $(0.853)$ & $(0.408)$ & $(1.919)$ & $(0.791)$ & $(0.532)$ \\
& $1.275^{*}$ & 0.643 & 1.167 & $1.996 * * *$ & $-7.224 * *$ & -0.0837 & -0.331 \\
Booker*Other & $(0.674)$ & $(0.503)$ & $(1.434)$ & $(0.603)$ & $(3.042)$ & $(1.258)$ & $(0.561)$ \\
& 0.177 & -0.112 & $4.832 *$ & 0.703 & -3.872 & $1.627 *$ & 1.623 \\
Black & $(1.415)$ & $(1.007)$ & $(2.552)$ & $(1.018)$ & $(3.737)$ & $(0.903)$ & $(1.885)$ \\
& $4.265^{* * *}$ & -0.00646 & $1.791 * * *$ & 0.203 & 0.908 & -0.250 & -0.461 \\
Hispanic & $(0.647)$ & $(0.468)$ & $(0.613)$ & $(0.172)$ & $(0.968)$ & $(0.230)$ & $(0.332)$ \\
& $3.594 * * *$ & -0.173 & -0.926 & $-0.672 * * *$ & 2.745 & -0.474 & -0.471 \\
Other & $(0.454)$ & $(0.484)$ & $(0.912)$ & $(0.224)$ & $(2.477)$ & $(0.450)$ & $(0.317)$ \\
& 1.686 & 1.047 & 0.319 & -0.137 & -1.195 & -0.167 & 0.183 \\
Booker & $(1.447)$ & $(1.116)$ & $(2.175)$ & $(0.337)$ & $(2.698)$ & $(0.445)$ & $(0.647)$ \\
& $-3.927 * *$ & $-0.859 *$ & -2.090 & $-2.721 * *$ & $-9.703 *$ & 0.781 & 0.859 \\
Observations & $(1.716)$ & $(0.506)$ & $(2.520)$ & $(1.159)$ & $(5.604)$ & $(1.380)$ & $(2.751)$ \\
R-squared & 299,687 & 123,882 & 69,241 & 59,130 & 21,704 & 12,222 & 9,546 \\
Nos & 0.752 & 0.812 & 0.720 & 0.749 & 0.687 & 0.795 & 0.785 \\
\hline
\end{tabular}

Notes: Data is from the USSC from 1994-2009. Column 1 includes controls for primary drug type. All regressions contain dummies for each offense level and criminal history combination. Regressions also contain district by sentencing year, and sentencing month fixed effects, and standard errors are clustered at the district level. Race specific trends are excluded because of limited variation, but magnitudes are unchanged when race trends are included. $* * *=$ significant at 1 percent level, $* *=$ significant at 5 percent level, $*=$ significant at 10 percent level. 
Table A5. Other Sentencing Outcomes

\begin{tabular}{|c|c|c|c|c|}
\hline & $\begin{array}{c}(1) \\
\text { Incarceration }\end{array}$ & $\begin{array}{c}(2) \\
\text { Probation } \\
\text { Length }\end{array}$ & $\begin{array}{c}\text { (3) } \\
\text { Supervised Release } \\
\text { Receipt }\end{array}$ & $\begin{array}{c}(4) \\
\text { Supervised } \\
\text { Release }\end{array}$ \\
\hline Booker*Black & 0.00525 & -0.146 & 0.00154 & $-1.522^{* * *}$ \\
\hline & $(0.00392)$ & $(0.635)$ & $(0.00132)$ & $(0.316)$ \\
\hline Booker*Hispanic & $\begin{array}{l}0.00806^{*} \\
(0.00437)\end{array}$ & $\begin{array}{l}2.119^{*} \\
(1109)\end{array}$ & $\begin{array}{l}-0.00129 \\
(0.00283)\end{array}$ & $\begin{array}{c}-1.433 * * * \\
(0.322)\end{array}$ \\
\hline Booker*Other & $\begin{array}{c}0.00260 \\
(0.00870)\end{array}$ & $\begin{array}{l}-1.894^{*} \\
(0.998)\end{array}$ & $\begin{array}{c}-0.00723 * \\
(0.00376)\end{array}$ & $\begin{array}{c}-2.529 * * * \\
(0.553)\end{array}$ \\
\hline Black & $\begin{array}{c}0.0172 * * * \\
(0.00319)\end{array}$ & $\begin{array}{l}-0.269 \\
(0.512)\end{array}$ & $\begin{array}{c}-0.00249 * * \\
(0.00123)\end{array}$ & $\begin{array}{c}1.771 * * * \\
(0.224)\end{array}$ \\
\hline Hispanic & $\begin{array}{l}0.00776^{*} \\
(0.00447)\end{array}$ & $\begin{array}{c}-5.952 * * * \\
(0.863)\end{array}$ & $\begin{array}{r}-0.000426 \\
(0.00248)\end{array}$ & $\begin{array}{c}0.124 \\
(0.246)\end{array}$ \\
\hline Other & $\begin{array}{c}-0.00533 \\
(0.00865)\end{array}$ & $\begin{array}{l}1.265 \\
(0.963)\end{array}$ & $\begin{array}{c}0.0145^{* *} * \\
(0.00650)\end{array}$ & $\begin{array}{l}1.085 * * \\
(0.441)\end{array}$ \\
\hline Booker & $\begin{array}{c}-0.0212 * * * * \\
(0.00733)\end{array}$ & $\begin{array}{c}-2.400 * * * \\
(0.855)\end{array}$ & $\begin{array}{l}0.00861 * \\
(0.00499)\end{array}$ & $\begin{array}{l}0.932 * \\
(0.501)\end{array}$ \\
\hline $\begin{array}{l}\text { Race Trends? } \\
\text { Observations }\end{array}$ & $\begin{array}{c}\text { Yes } \\
817,222\end{array}$ & $\begin{array}{c}\text { Yes } \\
137,499\end{array}$ & $\begin{array}{c}\text { Yes } \\
678,699\end{array}$ & $\begin{array}{c}\text { Yes } \\
666,846\end{array}$ \\
\hline R-squared & 0.468 & 0.356 & 0.139 & 0.454 \\
\hline
\end{tabular}

Notes: Data is from the USSC from 1994-2009. All regressions contain controls for offense type, and dummies for each offense level and criminal history combination. Regressions also contain district by sentencing year, and sentencing month fixed effects, and standard errors are clustered at the district level. Race trends are included. $* * *=$ significant at 1 percent level, $* *$ $=$ significant at 5 percent level, $*=$ significant at 10 percent level. 
Table A6. Acceptance of Responsibility Reduction

\begin{tabular}{lccc}
\hline \hline & $(1)$ & $(2)$ & $(3)$ \\
& 2 Point Reduction & 3 Point Reduction & Any Reduction \\
\hline Booker*Black & 0.00556 & -0.00299 & -0.00445 \\
Booker*Hispanic & $(0.00550)$ & $(0.00475)$ & $(0.00368)$ \\
Booker*Other & 0.00433 & 0.000752 & -0.00140 \\
& $(0.00553)$ & $(0.00433)$ & $(0.00391)$ \\
Black & $0.0200^{* *}$ & 0.0178 & $0.0130^{*}$ \\
& $(0.00908)$ & $(0.0111)$ & $(0.00658)$ \\
Hispanic & $-0.0114 * * *$ & $-0.0314^{* * *}$ & $-0.0177 * * *$ \\
& $(0.00397)$ & $(0.00349)$ & $(0.00270)$ \\
Other & $0.0174 * * *$ & $-0.00817 *$ & 0.00215 \\
& $(0.00453)$ & $(0.00459)$ & $(0.00416)$ \\
Booker & $-0.0206 * * *$ & -0.000458 & -0.00305 \\
& $(0.00650)$ & $(0.0104)$ & $(0.00757)$ \\
Race Trends? & 0.000354 & -0.00246 & -0.000984 \\
Observations & $(0.0111)$ & $(0.00775)$ & $(0.00616)$ \\
R-squared & Yes & Yes & Yes \\
Nos: & 326,524 & 569,481 & 822,002 \\
& 0.596 & 0.399 & 0.272
\end{tabular}

Notes: Data is from the USSC from 1994-2009. All regressions contain controls for offense type, and dummies for each offense level and criminal history combination. Regressions also contain district by sentencing year, and sentencing month fixed effects, and standard errors are clustered at the district level. Race trends are included. $* * *=$ significant at 1 percent level, ${ }^{* *}=$ significant at 5 percent level, $*=$ significant at 10 percent level. 
Table A7. Dynamic Specification, Black White Gap

\begin{tabular}{|c|c|c|c|}
\hline & $\begin{array}{c}(1) \\
\text { Black White Gap } \\
\text { Sentence }\end{array}$ & $\begin{array}{c}(2) \\
\text { Black White Gap } \\
\text { Above Range }\end{array}$ & $\begin{array}{c}(3) \\
\text { Black White Gap } \\
\text { Below Range }\end{array}$ \\
\hline 55-60 Months Before & 1.240 & -0.000592 & -0.00776 \\
\hline & $(0.908)$ & $(0.00497)$ & $(0.0111)$ \\
\hline 49-54 Months Before & -0.0703 & -0.00332 & -0.00183 \\
\hline & $(1.071)$ & $(0.00549)$ & $(0.0103)$ \\
\hline 43-48 Months Before & $\begin{array}{l}-0.393 \\
(0.867)\end{array}$ & $\begin{array}{c}-0.0109 * * \\
(0.00508)\end{array}$ & $\begin{array}{c}-0.00248 \\
(0.00967)\end{array}$ \\
\hline 37-42 Months Before & $\begin{array}{c}0.227 \\
(0.847)\end{array}$ & $\begin{array}{l}-0.00367 \\
(0.00519)\end{array}$ & $\begin{array}{c}-0.0115 \\
(0.00797)\end{array}$ \\
\hline 31-36 Months Before & $\begin{array}{l}1.225 \\
(1.107)\end{array}$ & $\begin{array}{l}-0.00616 \\
(0.00469)\end{array}$ & $\begin{array}{c}-0.00888 \\
(0.00978)\end{array}$ \\
\hline 25-30 Months Before & $\begin{array}{c}-0.283 \\
(0.760)\end{array}$ & $\begin{array}{l}-0.00755 \\
(0.00515)\end{array}$ & $\begin{array}{r}0.00738 \\
(0.0115)\end{array}$ \\
\hline 19-24 Months Before & $\begin{array}{l}1.245 \\
(0.814)\end{array}$ & $\begin{array}{l}-0.00599 \\
(0.00468)\end{array}$ & $\begin{array}{l}-0.00305 \\
(0.0101))\end{array}$ \\
\hline 13-18 Months Before & $\begin{array}{c}0.898 \\
(0.850)\end{array}$ & $\begin{array}{c}-0.0103 * * \\
(0.00415)\end{array}$ & $\begin{array}{l}-0.00122 \\
(0.00928)\end{array}$ \\
\hline 7-12 Months Before & $\begin{array}{c}0.897 \\
(0.791)\end{array}$ & $\begin{array}{c}-0.00564 \\
(0.00451)\end{array}$ & $\begin{array}{l}0.00753 \\
(0.0105)\end{array}$ \\
\hline 1-6 Months Before & $\begin{array}{c}0.690 \\
(1.119)\end{array}$ & $\begin{array}{l}-0.00257 \\
(0.00568)\end{array}$ & $\begin{array}{c}0.0103 \\
(0.00923)\end{array}$ \\
\hline 1-6 Months After & $\begin{array}{l}1.060 \\
(0.988)\end{array}$ & $\begin{array}{c}-0.00973^{*} \\
(0.00579)\end{array}$ & $\begin{array}{c}-0.00192 \\
(0.0122)\end{array}$ \\
\hline 7-12 Months After & $\begin{array}{l}1.530 \\
(1.287)\end{array}$ & $\begin{array}{l}-0.00363 \\
(0.00713)\end{array}$ & $\begin{array}{r}0.00142 \\
(0.0114)\end{array}$ \\
\hline 13-18 Months After & $\begin{array}{l}1.729 \\
(1.101)\end{array}$ & $\begin{array}{l}-0.00556 \\
(0.00535)\end{array}$ & $\begin{array}{c}-6.17 \mathrm{e}-05 \\
(0.0105)\end{array}$ \\
\hline 19-24 Months After & $\begin{array}{c}1.566 \\
(1.279)\end{array}$ & $\begin{array}{c}-0.000684 \\
(0.00636)\end{array}$ & $\begin{array}{c}-0.0161 \\
(0.0115)\end{array}$ \\
\hline 25-30 Months After & $\begin{array}{c}2.526 * * \\
(1.057)\end{array}$ & $\begin{array}{c}0.00963 \\
(0.00608)\end{array}$ & $\begin{array}{r}-0.00910 \\
(0.0109)\end{array}$ \\
\hline 31-36 Months After & $\begin{array}{c}3.274 * * * \\
(1.229)\end{array}$ & $\begin{array}{l}0.0140 * * \\
(0.00596)\end{array}$ & $\begin{array}{c}-0.0204^{*} \\
(0.0104)\end{array}$ \\
\hline 37-42 Months After & $\begin{array}{c}3.645 * * * \\
(1.026)\end{array}$ & $\begin{array}{c}0.0207 * * * \\
(0.00499)\end{array}$ & $\begin{array}{c}-0.0333 * * * \\
(0.0123)\end{array}$ \\
\hline 43-48 Months After & $\begin{array}{c}4.408 * * * \\
(1.106)\end{array}$ & $\begin{array}{c}0.0288 * * * \\
(0.00639)\end{array}$ & $\begin{array}{c}-0.0516^{* * *} \\
(0.0112)\end{array}$ \\
\hline 49-54 Months After & $\begin{array}{c}4.323 * * * \\
(1.152)\end{array}$ & $\begin{array}{c}0.0259 * * * \\
(0.00702)\end{array}$ & $\begin{array}{c}-0.0375 * * * * \\
(0.0124)\end{array}$ \\
\hline 55-58 Months After & $\begin{array}{l}2.887 * \\
(1.578)\end{array}$ & $\begin{array}{c}0.0348 * * * \\
(0.00913)\end{array}$ & $\begin{array}{c}-0.0223 \\
(0.0147)\end{array}$ \\
\hline Observations & 692,039 & 692,039 & 692,039 \\
\hline R-squared & 0.741 & 0.169 & 0.193 \\
\hline
\end{tabular}

Notes: Data is from the USSC from 1994-2009. Coefficients are for the differential outcome for black vs. white defendants from a dynamic DD regression identical to specification (1) in Table II, but with leads and lags for the five years before and five years after Booker, interacted with defendant race. All regressions contain controls for offense type, and dummies for each offense level and criminal history combination. Regressions also contain district by sentencing year, and sentencing month fixed effects, and standard errors are clustered at the district level. Race trends are excluded. $* * *=$ significant at 1 percent level, $* *=$ significant at 5 percent level, $*=$ significant at 10 percent level. 
Table A8. Defendant Demographic Characteristics

\begin{tabular}{|c|c|c|c|c|c|}
\hline & $\begin{array}{l}\text { (1) } \\
\text { Male }\end{array}$ & $\begin{array}{l}\text { (2) } \\
\text { Age }\end{array}$ & $\begin{array}{c}(3) \\
\text { Number } \\
\text { Dependents }\end{array}$ & $\begin{array}{c}(4) \\
\text { Non US } \\
\text { Citizen }\end{array}$ & $\begin{array}{c}(5) \\
\text { Less than } \\
\text { HS }\end{array}$ \\
\hline Booker*Black & $\begin{array}{c}0.0234 * * * \\
(0.00698)\end{array}$ & $\begin{array}{c}-0.715 * * * * \\
(0.139)\end{array}$ & $\begin{array}{c}0.0375 \\
(0.0246)\end{array}$ & $\begin{array}{c}-0.0209 * * * * \\
(0.00734)\end{array}$ & $\begin{array}{r}-0.00324 \\
(0.00553)\end{array}$ \\
\hline Booke & $\begin{array}{c}0.00756 \\
(0.00531)\end{array}$ & $\begin{array}{l}-0.113 \\
(0.156)\end{array}$ & $\begin{array}{c}0.0335 \\
(0.0312)\end{array}$ & $\begin{array}{c}0.00909 \\
(0.00980)\end{array}$ & $\begin{array}{c}0.00125 \\
(0.00709)\end{array}$ \\
\hline Booker*Other & $\begin{array}{l}0.00976 \\
(0.0110)\end{array}$ & $\begin{array}{l}-0.568 \\
(0.342)\end{array}$ & $\begin{array}{c}-0.0553 \\
(0.0517)\end{array}$ & $\begin{array}{l}0.0205 * \\
(0.0108)\end{array}$ & $\begin{array}{c}0.0247 * * \\
(0.0117)\end{array}$ \\
\hline Black & $\begin{array}{c}-0.0258 * * \\
(0.0100)\end{array}$ & $\begin{array}{c}-4.455 * * * \\
(0.166)\end{array}$ & $\begin{array}{c}0.595 * * * \\
(0.0287)\end{array}$ & $\begin{array}{c}0.0274 * * \\
(0.0120)\end{array}$ & $\begin{array}{c}0.0743 * * * \\
(0.00768)\end{array}$ \\
\hline Hispe & $\begin{array}{c}0.00317 \\
(0.00665)\end{array}$ & $\begin{array}{c}-4.086 * * * \\
(0.194)\end{array}$ & $\begin{array}{c}0.463 * * * \\
(0.0301)\end{array}$ & $\begin{array}{c}0.408 * * * \\
(0.0183)\end{array}$ & $\begin{array}{c}0.213 * * * \\
(0.0116)\end{array}$ \\
\hline Other & $\begin{array}{c}-0.0354 * * * \\
(0.00803)\end{array}$ & $\begin{array}{c}-3.227 * * * \\
(0.271)\end{array}$ & $0.267 * * *$ & $0.162 * * *$ & $\begin{array}{l}0.0319 * \\
(0.0178)\end{array}$ \\
\hline Booker & $\begin{array}{l}-0.00310 \\
(0.00822)\end{array}$ & $\begin{array}{c}0.400 \\
(0.278)\end{array}$ & $\begin{array}{l}-0.0674 \\
(0.0473)\end{array}$ & $\begin{array}{l}-0.00134 \\
(0.00978)\end{array}$ & $\begin{array}{l}-0.0138 \\
(0.0128)\end{array}$ \\
\hline $\begin{array}{l}\text { Race Trends? } \\
\text { Observations }\end{array}$ & $\begin{array}{c}\text { Yes } \\
824,680\end{array}$ & $\begin{array}{c}\text { Yes } \\
824,680\end{array}$ & $\begin{array}{c}\text { Yes } \\
824,680\end{array}$ & $\begin{array}{c}\text { Yes } \\
824,680\end{array}$ & $\begin{array}{c}\text { Yes } \\
824,680\end{array}$ \\
\hline R-squared & 0.135 & 0.182 & 0.125 & 0.568 & 0.240 \\
\hline
\end{tabular}

Notes: Data is from the USSC from 1994-2009. All regressions contain controls for offense type, and dummies for each offense level and criminal history combination. Regressions also contain district by sentencing year, and sentencing month fixed effects, and standard errors are clustered at the district level. Race trends are included. $* * *=$ significant at 1 percent level, $* *=$ significant at 5 percent level, $*$ = significant at 10 percent level. 
Table A9. Defendant Criminal Characteristics

\begin{tabular}{lcccccc}
\hline \hline & $\begin{array}{c}(1) \\
\text { Crim } \\
\text { History }\end{array}$ & $\begin{array}{c}\text { Total Crim } \\
\text { Points }\end{array}$ & $\begin{array}{c}\text { Crim History } \\
\text { Category }\end{array}$ & $\begin{array}{c}(4) \\
\text { Base } \\
\text { Offense }\end{array}$ & $\begin{array}{c}(5) \\
\text { Ch. } 2 \\
\text { Offense }\end{array}$ & $\begin{array}{c}(6) \\
\text { Final } \\
\text { Offense }\end{array}$ \\
\hline Booker*Black & 0.00347 & 0.104 & 0.0330 & $-0.201 * *$ & $-0.356^{* * *}$ & $-0.413^{* * * *}$ \\
& $(0.00623)$ & $(0.0984)$ & $(0.0261)$ & $(0.0896)$ & $(0.135)$ & $(0.112)$ \\
Booker*Hispanic & -0.00669 & 0.0438 & -0.220 & -0.0295 & -0.0805 & $-0.835^{* * *}$ \\
& $(0.00769)$ & $(0.252)$ & $(0.0352)$ & $(0.158)$ & $(0.186)$ & $(0.148)$ \\
Booker*Other & $0.0277 * *$ & 0.115 & 0.0208 & 0.203 & 0.431 & 0.228 \\
& $(0.0133)$ & $(0.156)$ & $(0.0517)$ & $(0.236)$ & $(0.298)$ & $(0.246)$ \\
Black & $0.0800 * * *$ & $1.717 * * *$ & $0.607 * * *$ & $0.968 * * *$ & $0.604 * * *$ & $0.858 * * *$ \\
& $(0.00583)$ & $(0.104)$ & $(0.0269)$ & $(0.120)$ & $(0.147)$ & $(0.153)$ \\
Hispanic & $-0.0236 * * *$ & $-0.445 * *$ & $-0.0753 * *$ & -0.220 & 0.451 & $0.703 * * *$ \\
& $(0.00787)$ & $(0.177)$ & $(0.0309)$ & $(0.158)$ & $(0.278)$ & $(0.261)$ \\
Other & $-0.0671 * * *$ & $-0.980 * * *$ & $-0.273 * * *$ & 0.203 & -0.330 & -0.0818 \\
& $(0.0146)$ & $(0.150)$ & $(0.0535)$ & $(0.236)$ & $(0.264)$ & $(0.231)$ \\
Booker & -0.00223 & -0.224 & -0.0398 & $0.689 * * *$ & $0.756 * * *$ & $1.239 * * *$ \\
& $(0.0127)$ & $(0.185)$ & $(0.0366)$ & $(0.167)$ & $(0.196)$ & $(0.203)$ \\
Observations & 636,698 & 822,908 & 824,680 & 822,678 & 553,759 & 824,680 \\
R-squared & 0.224 & 0.206 & 0.307 & $(0.442)$ & 0.541 & 0.522 \\
\hline
\end{tabular}

Notes: Data is from the USSC from 1994-2009. When the dependent variable is the Chapter 2 adjusted offense level, data is from 1999-2009. Regressions for criminal history, total criminal history points and criminal history category contain controls for final offense level. Regressions for Chapter 2 and final offense level control for criminal history category. All regressions contain controls for offense type. Regressions also contain district by sentencing year, and sentencing month fixed effects, and standard errors are clustered at the district level. Race trends are included. $* * *=$ significant at 1 percent level, $* *=$ significant at 5 percent level, $*=$ significant at 10 percent level. 
Table A10. Sentencing Departures from the Guidelines Base Offense Level Control

\begin{tabular}{lccccccc}
\hline \hline & $(1)$ & $(2)$ & $(3)$ & $(4)$ & $(5)$ & $(6)$ & $(7)$ \\
& $\begin{array}{c}\text { Sentence } \\
\text { Range }\end{array}$ & $\begin{array}{c}\text { Months } \\
\text { Above }\end{array}$ & $\begin{array}{c}\text { Below } \\
\text { Range }\end{array}$ & $\begin{array}{c}\text { Months } \\
\text { Below }\end{array}$ & $\begin{array}{c}\text { Within } \\
\text { Range }\end{array}$ & $\begin{array}{c}\text { Months } \\
\text { Within }\end{array}$ \\
\hline Booker*Black & $1.895^{* *}$ & $0.0196 * * *$ & 0.142 & $-0.0174 * *$ & $-23.61 *$ & -0.00230 & 0.711 \\
& $(0.778)$ & $(0.00379)$ & $(3.294)$ & $(0.00729)$ & $(13.64)$ & $(0.00609)$ & $(0.720)$ \\
Booker*Hispanic & 0.188 & $0.0105 * * *$ & 3.857 & 0.00465 & -5.967 & -0.0152 & $-1.397 * *$ \\
& $(0.595)$ & $(0.00381)$ & $(3.181)$ & $(0.0101)$ & $(16.25)$ & $(0.00921)$ & $(0.600)$ \\
Booker*Other & 0.717 & 0.0104 & 3.893 & 0.00711 & 5.696 & -0.0175 & -0.378 \\
& $(1.211)$ & $(0.00665)$ & $(7.433)$ & $(0.0148)$ & $(27.49)$ & $(0.0152)$ & $(1.061)$ \\
Black & $2.894 * * *$ & 0.00247 & 2.825 & $-0.0522^{* * *}$ & 8.118 & $0.0497 * * *$ & -0.981 \\
& $(0.680)$ & $(0.00326)$ & $(2.634)$ & $(0.00776)$ & $(10.21)$ & $(0.00781)$ & $(0.620)$ \\
Hispanic & -0.491 & $-0.00790^{* * *}$ & $-4.412 *$ & $-0.0667 * * *$ & -3.500 & $0.0746 * * *$ & $-2.150^{* * *}$ \\
& $(0.617)$ & $(0.00273)$ & $(2.339)$ & $(0.00804)$ & $(8.147)$ & $(0.00866)$ & $(0.658)$ \\
Other & $3.994 * * *$ & $0.00882^{*}$ & 2.874 & $-0.0543 * *$ & -15.11 & $0.0455^{*}$ & $2.9866^{* * *}$ \\
& $(1.213)$ & $(0.00463)$ & $(5.349)$ & $(0.0240)$ & $(15.84)$ & $(0.0241)$ & $(1.018)$ \\
Booker & 0.271 & 0.00214 & 4.891 & $0.0981 * * *$ & $34.63 * * *$ & $-0.100 * * *$ & $2.180^{* *}$ \\
& $(1.259)$ & $(0.00731)$ & $(4.087)$ & $(0.0135)$ & $(13.06)$ & $(0.0142)$ & $(1.085)$ \\
Race Trends? & Yes & Yes & Yes & Yes & Yes & Yes & Yes \\
Observations & 677,711 & 677,711 & 41,379 & 677,711 & 255,167 & 677,711 & 381,138 \\
R-squared & 0.580 & 0.174 & 0.215 & 0.162 & 0.118 & 0.136 & 0.768 \\
\hline
\end{tabular}

Notes: Data is from the USSC from 1994-2009. All regressions contain controls for offense type, and dummies for each base offense level and criminal history combination. Regressions also contain district by sentencing year, and sentencing month fixed effects, and standard errors are clustered at the district level. $* * *=$ significant at 1 percent level, $* *=$ significant at 5 percent level, $*$ = significant at 10 percent level. 
Table A11. Sentence Length in Months Linked Arrest Through Sentencing

\begin{tabular}{|c|c|c|}
\hline & $\begin{array}{c}(1) \\
\text { Sentence }\end{array}$ & $\begin{array}{c}(2) \\
\text { Sentence }\end{array}$ \\
\hline Booker*Black & $\begin{array}{l}1.796 * * \\
(0.732)\end{array}$ & $\begin{array}{l}2.258 * * \\
(1.089)\end{array}$ \\
\hline Black & $\begin{array}{c}2.038 * * * \\
(0.556)\end{array}$ & $\begin{array}{c}3.868 * * * \\
(0.952)\end{array}$ \\
\hline Booker & $\begin{array}{c}-2.361 * * \\
(1.131)\end{array}$ & $\begin{array}{l}3.359 * * \\
(1.603)\end{array}$ \\
\hline Non US Citizen & $\begin{array}{c}1.718 * * * \\
(0.457)\end{array}$ & $\begin{array}{l}1.096 \\
(0.678)\end{array}$ \\
\hline HS Grad & $\begin{array}{c}-0.589^{* * * *} \\
(0.202)\end{array}$ & $\begin{array}{c}0.429 \\
(0.291)\end{array}$ \\
\hline Some College & $\begin{array}{c}-1.646^{* * * *} \\
(0.214)\end{array}$ & $\begin{array}{l}-0.272 \\
(0.412)\end{array}$ \\
\hline College Grad & $\begin{array}{c}-2.282 * * * \\
(0.241)\end{array}$ & $\begin{array}{c}2.105^{* * *} * \\
(0.641)\end{array}$ \\
\hline \# Dependents & $\begin{array}{c}-0.158 * * * \\
(0.0470)\end{array}$ & $\begin{array}{c}0.564 * * * \\
(0.0965)\end{array}$ \\
\hline Female & $\begin{array}{c}-5.295 * * * \\
(0.514)\end{array}$ & $\begin{array}{c}-10.94 * * * \\
(0.878)\end{array}$ \\
\hline Age & $\begin{array}{c}0.144 * * * \\
(0.0368)\end{array}$ & $\begin{array}{c}0.452 * * * \\
(0.0583)\end{array}$ \\
\hline $\mathrm{Age}^{2}$ & $\begin{array}{c}-0.00165^{* * * *} \\
(0.000437)\end{array}$ & $\begin{array}{c}-0.00325^{* * *} \\
(0.000676)\end{array}$ \\
\hline $\begin{array}{l}\text { Race Trends? } \\
\text { Observations } \\
\text { R-squared }\end{array}$ & $\begin{array}{c}\text { Yes } \\
340,755 \\
0.749\end{array}$ & $\begin{array}{c}\text { Yes } \\
342,056 \\
0.469\end{array}$ \\
\hline \multicolumn{3}{|c|}{$\begin{array}{l}\text { Notes: Data is from the linked arrest through sentenc- } \\
\text { ing dataset from 1994-2009. Column } 1 \text { replicates the } \\
\text { main results in Table II. Column } 2 \text { controls for arrest } \\
\text { offense, rather than final offense level. Regressions } \\
\text { also contain district by sentencing year, and sentencing } \\
\text { month fixed effects, and standard errors are clustered } \\
\text { at the district level. Race trends are included. } * * *= \\
\text { significant at } 1 \text { percent level, } * *=\text { significant at } 5 \text { per- } \\
\text { cent level, } *=\text { significant at } 10 \text { percent level. }\end{array}$} \\
\hline
\end{tabular}


Table A12. Selection into Sentencing Stage

\begin{tabular}{lccc}
\hline \hline & $\begin{array}{c}(1) \\
\text { Guilty Plea }\end{array}$ & $\begin{array}{c}(2) \\
\text { Dropped Charge }\end{array}$ & $\begin{array}{c}(3) \\
\text { Deferred Prosecution }\end{array}$ \\
\hline Booker*Black & -0.0115 & $-0.00451 *$ & 0.000103 \\
& $(0.00808)$ & $(0.00242)$ & $(0.000901)$ \\
Black & -0.00718 & $0.00634 * * *$ & -0.000823 \\
& $(0.00948)$ & $(0.00218)$ & $(0.000854)$ \\
Booker & $-0.112 * * *$ & -0.00186 & $-5.74 \mathrm{e}-05$ \\
& $(0.00779)$ & $(0.00351)$ & $(0.000385)$ \\
Observations & $1,669,560$ & $1,669,560$ & $1,669,560$ \\
R-squared & 0.241 & 0.043 & 0.032 \\
\hline Notes: Data is from the Arrests and Bookings for Federal Offenses from 1994- \\
2009. All regressions contain controls for defendant gender, age, marital status, \\
citizenship status, primary offense type, district court by arrest year fixed effects, \\
and race trends. Standard errors are clustered at the district level. The coefficient \\
of interest is the interaction of defendant race (omitted group white defendants) \\
with a Booker indicator for defendants arrested after Booker. Race trends are \\
included. *** = significant at 1 percent level, ** = significant at 5 percent level, * \\
$=$ significant at 10 percent level.
\end{tabular}


Table A13. Randomization Tests 2000-2009

\begin{tabular}{|c|c|c|}
\hline District Court & No. Obs. & p-value \\
\hline $\mathrm{ME}(0)$ & 1,668 & 0.1438 \\
\hline MA (1) & 4,042 & 0.1054 \\
\hline $\mathrm{NH}(2)$ & 1,617 & 0.9844 \\
\hline PR (4) & 6520 & 0.2674 \\
\hline $\mathrm{CT} * *(5)$ & 664 & 0.0000 \\
\hline NY North - Syracuse (6) & 1,148 & 0.1074 \\
\hline NY East** (7) & 12,447 & 0.0004 \\
\hline NY South - White Plains (8) & 1,338 & 0.4336 \\
\hline NY West - Rochester (9) & 1,166 & 0.6226 \\
\hline VT (10) & 1,400 & 0.2379 \\
\hline DE (11) & 641 & 0.3831 \\
\hline NJ -Trenton (12) & 476 & 0.2983 \\
\hline PA East** (13) & 6,411 & 0.0000 \\
\hline PA Middle - Scranton (14) & 969 & 0.6837 \\
\hline PA Middle - Williamsport (14) & 234 & 0.2071 \\
\hline PA West - Erie (15) & 609 & 0.0521 \\
\hline PA West - Pittsburgh (15) & 2,917 & 0.0645 \\
\hline MD (16) & 5,569 & 0.0631 \\
\hline NC East - Southern (17) & 608 & 0.3847 \\
\hline NC Middle (18) & 3,205 & 0.08086 \\
\hline NC West**(19) & 5,563 & 0.0000 \\
\hline $\mathrm{SC}^{* *}(20)$ & 8,848 & 0.0000 \\
\hline VA East -Alexandria (22) & 4,500 & 0.3178 \\
\hline VA East -Norfolk (22) & 1,105 & 0.1658 \\
\hline VA East -Newport News (22) & 743 & 0.0662 \\
\hline VA West (23) & 3,123 & 0.3250 \\
\hline WV North - Martinsburg (24) & 639 & 0.4091 \\
\hline WV South (25) & 1,778 & 0.0932 \\
\hline AL North** (26) & 1,430 & 0.0189 \\
\hline AL Middle (27) & 904 & 0.3242 \\
\hline AL South (28) & 3,132 & 0.0702 \\
\hline FL North (29) & 2,718 & 0.5783 \\
\hline FL Middle - Ft. Myers (30) & 923 & 0.3824 \\
\hline FL Middle - Ocala (30) & 465 & 0.3128 \\
\hline FL South - Ft. Pierce (31) & 3,299 & 0.0541 \\
\hline FL South - Ft. Lauderdale (31) & 649 & 0.2485 \\
\hline GA North** (32) & 5,823 & 0.0000 \\
\hline GA Middle (33) & 2,064 & 0.1396 \\
\hline LA East (35) & 3,117 & 0.0606 \\
\hline LA West (36) & 1,686 & .6360 \\
\hline MS North (37) & 925 & 0.4247 \\
\hline MS South (38) & 3,057 & 0.0564 \\
\hline TX North - Forth Worth (39) & 2,027 & 0.2386 \\
\hline TX East (40) & 6,563 & 0.5598 \\
\hline TX South - Brownsville (41) & 10,112 & 0.3364 \\
\hline TX South - Corpus Christi (41) & 6,679 & 0.2767 \\
\hline TX South - Laredo (41) & 19,079 & 0.6244 \\
\hline TX South - McAllen (41) & 12,739 & 0.1093 \\
\hline
\end{tabular}




$\begin{array}{lcc}\text { TX West - Del Rio (42) } & 7,098 & 0.3500 \\ \text { TX West - Midland-Odessa (42) } & 3,567 & 0.4120 \\ \text { KY East - Covington (43) } & 717 & 0.5872 \\ \text { KY East - Pikeville (43) } & 139 & 0.0966 \\ \text { KY East - Lexington (43) } & 1,993 & 0.8694 \\ \text { KY West (44) } & 1,746 & 0.1114 \\ \text { MI East - Bay City (45) } & 458 & 0.4009 \\ \text { MI East - Flint (45) } & 673 & 0.3014 \\ \text { MI West (46) } & 3,313 & 0.0961 \\ \text { OH North - Toledo (47) } & 1,014 & 0.2105 \\ \text { OH South - Dayton (48) } & 1,300 & 0.9115 \\ \text { TN East (49) } & 5,200 & 0.0705 \\ \text { TN Middle**(50) } & 1,938 & 0.0126 \\ \text { TN West - Eastern (51) } & 831 & 0.3998 \\ \text { IL North - Rockford (52) } & 624 & 0.8929 \\ \text { IL Central (53) } & 2,618 & 0.1283 \\ \text { IL South (54) } & 2,736 & 0.1296 \\ \text { IN North - South Bend (55) } & 954 & 0.2764 \\ \text { IN North - Fort Wayne (55) } & 530 & 0.0741 \\ \text { IN South (56) } & 2,004 & 0.3266 \\ \text { WI East - Milwaukee (57) } & 2,206 & 0.4223 \\ \text { WI West (58) } & 1,571 & 0.1123 \\ \text { AR East (60) } & 2,739 & 0.1631 \\ \text { AR West**61) } & 1,098 & 0.0001 \\ \text { IA North (62) } & 2,413 & 0.0561 \\ \text { IA South (63) } & 2,684 & 0.8265 \\ \text { MN** (64) } & 4,815 & 0.0001 \\ \text { MO East (65) } & 8,203 & 0.0785 \\ \text { MO West (66) } & 6,764 & 0.1191 \\ \text { NE - Omaha (67) } & 2,323 & 0.0532 \\ \text { ND (68) } & 1,888 & 0.2250 \\ \text { SD - Aberdeen (69) } & 309 & 0.1479 \\ \text { SD - Pierre (69) } & 1,010 & 0.8757 \\ \text { AZ - Tuscon (70) } & 23,677 & 0.0961 \\ \text { AZ - Yuma (70) } & 2,449 & 0.3392 \\ \text { CA North (71) } & 3,045 & 0.1970 \\ \text { CA East (72) } & 8,094 & 0.0646 \\ \text { CA Central - Riverside (73) } & 157 & 0.4520 \\ \text { CA South - El Centro (74) } & 8,664 & 0.3442 \\ \text { CA South - Yuma (74) } & 89 & 0.3502 \\ \text { HI** (75) } & 3,351 & 0.0012 \\ \text { ID (76) } & 1,526 & 0.0544 \\ \text { MT - Missoula (77) } & 516 & 0.1698 \\ \text { MT - Great Falls (77) } & 1,003 & 0.2206 \\ \text { NV (78) } & 4,867 & 0.6549 \\ \text { OR - Eugene (79) } & 954 & 0.2261 \\ \text { OR - Medford (79) } & 434 & 0.6618 \\ \text { WA East - Spokane (80) } & 1,401 & 0.3100 \\ \text { WA West** (81) } & 5,302 & 0.0001 \\ \text { WA } & & \\ \text { MA } & & \end{array}$




\begin{tabular}{lcc} 
CO** (82) & 4,582 & 0.0000 \\
KS (83) & 5,509 & 0.2031 \\
NM (84) & 24,019 & 0.2924 \\
OK North (85) & 1,279 & 0.3240 \\
OK East (86) & 736 & 0.9312 \\
OK West** (87) & 1,809 & 0.0001 \\
UT (88) & 5,276 & 0.9421 \\
WY**(89) & 1,565 & 0.0002 \\
DC (90) & 346 & 0.5720 \\
AK (95) & 1,218 & 0.1105 \\
LA Middle** (96) & 1,112 & 0.0263 \\
\hline
\end{tabular}

Notes: Data is from the matched USSC, TRAC, Federal Judicial Center data from 2000-2009. I drop judges who retired or were terminated prior to 2000 , and judges and district offices with an annual caseload of less than 25 . For each district court, I control for district office by sentencing year, sentencing month, and judge fixed effects. P-values reported test whether judge fixed effects differ significantly from zero and are from a seemingly unrelated regression (SUR) on five defendant characteristics: defendant gender, age, black race indicator, number of dependents, and less than high school indicator. ** indicates dropped courthouses. 
Table A14. Main Results using Judge Matched Data

\begin{tabular}{|c|c|c|}
\hline & $\begin{array}{c}(1) \\
\text { Random Sample } \\
\text { Sentence }\end{array}$ & $\begin{array}{l}\text { Full Matched Sample } \\
\text { Sentence }\end{array}$ \\
\hline Booker*Black & $1.994 * * *$ & $2.486^{* * * *}$ \\
\hline & $(0.691)$ & $(0.546)$ \\
\hline Booker*Hispanic & 0.732 & $1.076^{* *}$ \\
\hline Booker*Other & $\begin{array}{c}(0.563) \\
0.170 \\
(0.880)\end{array}$ & $\begin{array}{l}(0.460) \\
1.535\end{array}$ \\
\hline Black & $\begin{array}{c}2.924 * * * \\
(0.584)\end{array}$ & $\begin{array}{c}2.315 * * * \\
(0.404)\end{array}$ \\
\hline Hispanic & $\begin{array}{c}2.155 * * * \\
(0.598)\end{array}$ & $\begin{array}{c}1.270 * * * \\
(0.467)\end{array}$ \\
\hline Other & $\begin{array}{c}3.070 * * * \\
(0.713)\end{array}$ & $\begin{array}{l}1.932 * \\
(1.040)\end{array}$ \\
\hline Booker & $\begin{array}{c}-2.897 * * * \\
(1.073)\end{array}$ & $\begin{array}{c}-2.811 * * * \\
(1.045)\end{array}$ \\
\hline Non US Citizen & $\begin{array}{c}0.433 \\
(0.496)\end{array}$ & $\begin{array}{l}1.283 * * \\
(0.502)\end{array}$ \\
\hline HS Grad & $\begin{array}{c}-0.701 * * * \\
(0.215)\end{array}$ & $\begin{array}{c}-0.555^{* * * *} \\
(0.186)\end{array}$ \\
\hline Some College & $\begin{array}{c}-1.434 * * * \\
(0.310)\end{array}$ & $\begin{array}{c}-1.762 * * * \\
(0.185)\end{array}$ \\
\hline College Grad & $\begin{array}{c}-2.119 * * * \\
(0.378)\end{array}$ & $\begin{array}{c}-2.068 * * * * \\
(0.247)\end{array}$ \\
\hline \# Dependents & $\begin{array}{c}-0.250 * * * \\
(0.0713)\end{array}$ & $\begin{array}{c}-0.236 * * * \\
(0.0477)\end{array}$ \\
\hline Female & $\begin{array}{c}-4.996 * * * \\
(0.515)\end{array}$ & $\begin{array}{c}-5.035 * * * \\
(0.508)\end{array}$ \\
\hline Age & $\begin{array}{c}0.241 * * * \\
(0.0606)\end{array}$ & $\begin{array}{c}0.190 * * * \\
(0.0446)\end{array}$ \\
\hline $\mathrm{Age}^{2}$ & $\begin{array}{c}-0.00263 * * * \\
(0.000704)\end{array}$ & $\begin{array}{c}-0.00208 * * * * \\
(0.000503)\end{array}$ \\
\hline Mandatory Min & $\begin{array}{c}22.13 * * * \\
(2.086)\end{array}$ & $\begin{array}{c}21.41 * * * \\
(1.841)\end{array}$ \\
\hline $\begin{array}{l}\text { Observations } \\
\text { R-squared }\end{array}$ & $\begin{array}{c}214,136 \\
0.784\end{array}$ & $\begin{array}{c}478,834 \\
0.754\end{array}$ \\
\hline \multicolumn{3}{|c|}{$\begin{array}{l}\text { Notes: Data is from the matched USSC, TRAC, Federal Judicial Center } \\
\text { data from } 2000-2009 \text {. Column } 1 \text { replicates column } 1 \text { from Table II using } \\
\text { the sample of random courts. Column } 2 \text { replicates column } 1 \text { of Table } \\
\text { II using the full matched sample. All regressions contain controls for } \\
\text { offense type, and dummies for each offense level and criminal history } \\
\text { combination. Regressions also contain district by sentencing year, and } \\
\text { sentencing month fixed effects, and standard errors are clustered at the } \\
\text { district level. } * * *=\text { significant at } 1 \text { percent level, } * *=\text { significant at } 5 \\
\text { percent level, } *=\text { significant at } 10 \text { percent level. }\end{array}$} \\
\hline
\end{tabular}


Table A15. Sentencing Patterns for Post Booker Judges Full Matched Sample

\begin{tabular}{|c|c|c|c|c|c|c|c|}
\hline & $\begin{array}{c}(1) \\
\text { Sentence }\end{array}$ & $\begin{array}{c}(2) \\
\text { Above } \\
\text { Range }\end{array}$ & $\begin{array}{c}(3) \\
\text { Months } \\
\text { Above }\end{array}$ & $\begin{array}{c}(4) \\
\text { Below } \\
\text { Range }\end{array}$ & $\begin{array}{c}(5) \\
\text { Months } \\
\text { Below }\end{array}$ & $\begin{array}{c}\text { (6) } \\
\text { Within } \\
\text { Range }\end{array}$ & $\begin{array}{c}(7) \\
\text { Months } \\
\text { Within }\end{array}$ \\
\hline Post Booker Judge & $\begin{array}{c}0.694 \\
(1.097)\end{array}$ & $\begin{array}{c}-0.00483 \\
(0.00601)\end{array}$ & $\begin{array}{l}-3.645 \\
(4.444)\end{array}$ & $\begin{array}{c}-0.0295 * \\
(0.0164)\end{array}$ & $\begin{array}{l}-2.806 \\
(4.064)\end{array}$ & $\begin{array}{c}0.0343 * * \\
(0.0162)\end{array}$ & $\begin{array}{c}-0.0298 \\
(0.258)\end{array}$ \\
\hline Post Booker Judge*Black & $\begin{array}{c}4.197 * * \\
(1.776)\end{array}$ & $\begin{array}{l}0.0234 * \\
(0.0135)\end{array}$ & $\begin{array}{c}2.973 \\
(4.455)\end{array}$ & $\begin{array}{l}-0.0109 \\
(0.0167)\end{array}$ & $\begin{array}{l}-4.228 \\
(6.711)\end{array}$ & $\begin{array}{l}-0.0125 \\
(0.0196)\end{array}$ & $\begin{array}{l}1.004 * * \\
(0.442)\end{array}$ \\
\hline Post Booker Judge*Hispanic & $\begin{array}{l}-0.147 \\
(1.059)\end{array}$ & $\begin{array}{c}0.0119 \\
(0.0133)\end{array}$ & $\begin{array}{l}-2.594 \\
(4.246)\end{array}$ & $\begin{array}{c}0.0138 \\
(0.0226)\end{array}$ & $\begin{array}{l}-1.786 \\
(4.525)\end{array}$ & $\begin{array}{l}-0.0257 \\
(0.0241)\end{array}$ & $\begin{array}{c}0.305 \\
(0.290)\end{array}$ \\
\hline Post Booker Judge*Other & $\begin{array}{c}-4.157 * * \\
(1.628)\end{array}$ & $\begin{array}{l}-0.00702 \\
(0.0139)\end{array}$ & $\begin{array}{l}-9.901 \\
(6.364)\end{array}$ & $\begin{array}{c}0.0919 * * * \\
(0.0318)\end{array}$ & $\begin{array}{l}-7.199 \\
(4.882)\end{array}$ & $\begin{array}{c}-0.0849 * * \\
(0.0343)\end{array}$ & $\begin{array}{c}0.627 \\
(0.845)\end{array}$ \\
\hline Booker & $\begin{array}{c}-2.763 * * \\
(1.051)\end{array}$ & $\begin{array}{c}0.00897 \\
(0.00697)\end{array}$ & $\begin{array}{l}-1.482 \\
(6.409)\end{array}$ & $\begin{array}{c}0.101 * * * \\
(0.0149)\end{array}$ & $\begin{array}{c}0.770 \\
(4.228)\end{array}$ & $\begin{array}{c}-0.110 * * * \\
(0.0147)\end{array}$ & $\begin{array}{l}-0.179 \\
(0.276)\end{array}$ \\
\hline Booker*Black & $\begin{array}{c}2.296 * * * \\
(0.542)\end{array}$ & $\begin{array}{c}0.0141 * * * \\
(0.00294)\end{array}$ & $\begin{array}{l}4.203 * \\
(2.278)\end{array}$ & $\begin{array}{c}-0.0170 * * \\
(0.00647)\end{array}$ & $\begin{array}{c}8.955 * * \\
(3.707)\end{array}$ & $\begin{array}{c}0.00296 \\
(0.00566)\end{array}$ & $\begin{array}{c}0.534 * * * \\
(0.187)\end{array}$ \\
\hline Booker*Hispanic & $\begin{array}{c}1.071 * * \\
(0.454)\end{array}$ & $\begin{array}{r}0.000226 \\
(0.00383)\end{array}$ & $\begin{array}{c}2.678 \\
(2.181)\end{array}$ & $\begin{array}{c}-0.00414 \\
(0.00935)\end{array}$ & $\begin{array}{c}3.231 \\
(2.743)\end{array}$ & $\begin{array}{c}0.00391 \\
(0.00834)\end{array}$ & $\begin{array}{c}0.328 * * * \\
(0.0911)\end{array}$ \\
\hline Booker*Other & $\begin{array}{l}1.717 \\
(1.035)\end{array}$ & $\begin{array}{c}0.00394 \\
(0.00461)\end{array}$ & $\begin{array}{c}0.351 \\
(5.212)\end{array}$ & $\begin{array}{c}-0.00673 \\
(0.0108)\end{array}$ & $\begin{array}{l}17.03^{*} \\
(10.24)\end{array}$ & $\begin{array}{l}0.00279 \\
(0.0106)\end{array}$ & $\begin{array}{c}-0.000959 \\
(0.233)\end{array}$ \\
\hline $\begin{array}{l}\text { Observations } \\
\text { R-squared }\end{array}$ & $\begin{array}{c}478,834 \\
0.754\end{array}$ & $\begin{array}{c}478,834 \\
0.169\end{array}$ & $\begin{array}{c}27,743 \\
0.274\end{array}$ & $\begin{array}{c}478,834 \\
0.204\end{array}$ & $\begin{array}{c}184,986 \\
0.842\end{array}$ & $\begin{array}{c}478,834 \\
0.172\end{array}$ & $\begin{array}{c}266,102 \\
0.983\end{array}$ \\
\hline
\end{tabular}

Notes: Data is from the matched USSC, TRAC, Federal Judicial Center data from 2000-2009. All regressions contain controls for offense type, and dummies for each offense level and criminal history combination. Regressions also contain district by sentencing year, and sentencing month fixed effects, and standard errors are clustered at the district level. *** $=$ significant at 1 percent level, $* *=$ significant at 5 percent level, $*=$ significant at 10 percent level. 
Table A16. Sentencing Patterns for Post Booker Judges

Subsample of Random Districts - Excluding Binding Statutory Minimums

\begin{tabular}{|c|c|c|c|c|c|c|c|}
\hline & $\begin{array}{c}(1) \\
\text { Sentence }\end{array}$ & $\begin{array}{c}(2) \\
\text { Above } \\
\text { Range }\end{array}$ & $\begin{array}{c}(3) \\
\text { Months } \\
\text { Above }\end{array}$ & $\begin{array}{c}\text { (4) } \\
\text { Below } \\
\text { Range }\end{array}$ & $\begin{array}{c}(5) \\
\text { Months } \\
\text { Below }\end{array}$ & $\begin{array}{c}(6) \\
\text { Within } \\
\text { Range }\end{array}$ & $\begin{array}{l}\text { (7) } \\
\text { Months } \\
\text { Within }\end{array}$ \\
\hline Post Booker Judge & $\begin{array}{c}0.233 \\
(1.162)\end{array}$ & $\begin{array}{c}0.00576 \\
(0.00656)\end{array}$ & $\begin{array}{c}10.78 \\
(9.189)\end{array}$ & $\begin{array}{l}-0.0113 \\
(0.0176)\end{array}$ & $\begin{array}{c}0.896 \\
(1.175)\end{array}$ & $\begin{array}{l}0.00552 \\
(0.0165)\end{array}$ & $\begin{array}{l}-0.631 * \\
(0.347)\end{array}$ \\
\hline Post Booker Judge*Black & $\begin{array}{l}3.913 * \\
(2.352)\end{array}$ & $\begin{array}{c}-0.00640 \\
(0.0108)\end{array}$ & $\begin{array}{l}-8.753 \\
(8.408)\end{array}$ & $\begin{array}{l}-0.00562 \\
(0.0279)\end{array}$ & $\begin{array}{l}-2.876 \\
(1.768)\end{array}$ & $\begin{array}{c}0.0120 \\
(0.0238)\end{array}$ & $\begin{array}{c}1.476 * * * \\
(0.508)\end{array}$ \\
\hline Post Booker Judge*Hispanic & $\begin{array}{l}-0.420 \\
(1.151)\end{array}$ & $\begin{array}{c}-0.00371 \\
(0.00940)\end{array}$ & $\begin{array}{l}-3.300 \\
(8.174)\end{array}$ & $\begin{array}{c}0.0122 \\
(0.0310)\end{array}$ & $\begin{array}{c}-0.382 \\
(1.902)\end{array}$ & $\begin{array}{c}-0.00846 \\
(0.0258)\end{array}$ & $\begin{array}{c}0.614 \\
(0.393)\end{array}$ \\
\hline Post Booker Judge*Other & $\begin{array}{l}1.282 \\
(2.711)\end{array}$ & $\begin{array}{c}0.0404 \\
(0.0280)\end{array}$ & $\begin{array}{c}4.062 \\
(16.72)\end{array}$ & $\begin{array}{c}0.0284 \\
(0.0601)\end{array}$ & $\begin{array}{c}1.850 \\
(3.017)\end{array}$ & $\begin{array}{l}-0.0687 \\
(0.0605)\end{array}$ & $\begin{array}{c}2.905 \\
(2.474)\end{array}$ \\
\hline Booker & $\begin{array}{c}-1.978 * * \\
(0.954)\end{array}$ & $\begin{array}{c}0.0120 \\
(0.00854)\end{array}$ & $\begin{array}{c}9.434 \\
(11.63)\end{array}$ & $\begin{array}{c}0.0752 * * * \\
(0.0226)\end{array}$ & $\begin{array}{l}-1.398 \\
(1.426)\end{array}$ & $\begin{array}{c}-0.0872 * * * \\
(0.0233)\end{array}$ & $\begin{array}{l}-0.345 \\
(0.426)\end{array}$ \\
\hline Booker*Black & $\begin{array}{c}0.395 \\
(0.632)\end{array}$ & $\begin{array}{c}0.00172 \\
(0.00340)\end{array}$ & $\begin{array}{l}-0.933 \\
(5.335)\end{array}$ & $\begin{array}{l}-0.00321 \\
(0.00790)\end{array}$ & $\begin{array}{l}-1.406^{*} \\
(0.737)\end{array}$ & $\begin{array}{c}0.00150 \\
(0.00805)\end{array}$ & $\begin{array}{l}0.382 * \\
(0.215)\end{array}$ \\
\hline Booker*Hispanic & $\begin{array}{l}1.097 * * \\
(0.534)\end{array}$ & $\begin{array}{l}0.00648 * \\
(0.00329)\end{array}$ & $\begin{array}{c}3.788 \\
(4.559)\end{array}$ & $\begin{array}{l}-0.0131 \\
(0.0182)\end{array}$ & $\begin{array}{c}0.00754 \\
(0.579)\end{array}$ & $\begin{array}{l}0.00667 \\
(0.0171)\end{array}$ & $\begin{array}{c}0.351 * * \\
(0.146)\end{array}$ \\
\hline Booker*Other & $\begin{array}{l}-0.371 \\
(0.887)\end{array}$ & $\begin{array}{l}0.000431 \\
(0.00881)\end{array}$ & $\begin{array}{c}2.917 \\
(7.044)\end{array}$ & $\begin{array}{l}-0.0109 \\
(0.0246)\end{array}$ & $\begin{array}{c}0.406 \\
(1.101)\end{array}$ & $\begin{array}{c}0.0104 \\
(0.0221)\end{array}$ & $\begin{array}{l}-0.524 \\
(0.398)\end{array}$ \\
\hline $\begin{array}{l}\text { Observations } \\
\text { R-squared }\end{array}$ & $\begin{array}{c}174,434 \\
0.840\end{array}$ & $\begin{array}{c}174,434 \\
0.064\end{array}$ & $\begin{array}{l}4,330 \\
0.608\end{array}$ & $\begin{array}{c}174,434 \\
0.255\end{array}$ & $\begin{array}{c}69,632 \\
0.752\end{array}$ & $\begin{array}{c}174,434 \\
0.231\end{array}$ & $\begin{array}{c}100,268 \\
0.987\end{array}$ \\
\hline
\end{tabular}

Notes: Data is from the matched USSC, TRAC, Federal Judicial Center data from 2000-2009 for courts with random assignment, excluding judges who formally retired prior to 2000. All regressions contain controls for offense type, and dummies for each offense level and criminal history combination. Regressions also contain district office by sentencing year, district court fixed effects, sentencing month fixed effects, and standard errors are clustered at the district level. $* * *=$ significant at 1 percent level, $* *=$ significant at 5 percent level, $*=$ significant at 10 percent level. 
Table A17. Sentencing for Post Booker Judges - Comparison to Pre Booker Bush Appointees Subsample of Random Districts

\begin{tabular}{|c|c|c|c|c|c|c|c|}
\hline & $\begin{array}{c}(1) \\
\text { Sentence }\end{array}$ & $\begin{array}{c}(2) \\
\text { Above } \\
\text { Range }\end{array}$ & $\begin{array}{c}(3) \\
\text { Months } \\
\text { Above }\end{array}$ & $\begin{array}{c}(4) \\
\text { Below } \\
\text { Range }\end{array}$ & $\begin{array}{c}\text { (5) } \\
\text { Months } \\
\text { Above }\end{array}$ & $\begin{array}{c}(6) \\
\text { Within } \\
\text { Range }\end{array}$ & $\begin{array}{c}\text { (7) } \\
\text { Months } \\
\text { Within }\end{array}$ \\
\hline Post Booker Judge & $\begin{array}{l}-1.002 \\
(1.702)\end{array}$ & $\begin{array}{c}-0.00562 \\
(0.0115)\end{array}$ & $\begin{array}{c}-0.424 \\
(7.811)\end{array}$ & $\begin{array}{c}-0.00969 \\
(0.0163)\end{array}$ & $\begin{array}{l}-1.785 \\
(6.092)\end{array}$ & $\begin{array}{c}0.0153 \\
(0.0148)\end{array}$ & $\begin{array}{c}-0.741 * * \\
(0.297)\end{array}$ \\
\hline Post Booker Judge*Black & $\begin{array}{l}5.694 * * \\
(2.621)\end{array}$ & $\begin{array}{c}0.0198 \\
(0.0150)\end{array}$ & $\begin{array}{c}6.018 \\
(6.666)\end{array}$ & $\begin{array}{l}-0.0140 \\
(0.0246)\end{array}$ & $\begin{array}{c}0.886 \\
(8.282)\end{array}$ & $\begin{array}{c}-0.00584 \\
(0.0194)\end{array}$ & $\begin{array}{l}1.245 * * \\
(0.496)\end{array}$ \\
\hline Post Booker Judge*Hispanic & $\begin{array}{c}-0.712 \\
(1.568)\end{array}$ & $\begin{array}{c}0.0147 \\
(0.0230)\end{array}$ & $\begin{array}{l}-7.757 \\
(7.942)\end{array}$ & $\begin{array}{c}0.0136 \\
(0.0282)\end{array}$ & $\begin{array}{l}-3.067 \\
(5.560)\end{array}$ & $\begin{array}{l}-0.0283 \\
(0.0309)\end{array}$ & $\begin{array}{c}0.812 * * \\
(0.371)\end{array}$ \\
\hline Post Booker Judge*Other & $\begin{array}{c}0.503 \\
(2.743)\end{array}$ & $\begin{array}{c}0.0389 \\
(0.0311)\end{array}$ & $\begin{array}{l}-11.31 \\
(13.03)\end{array}$ & $\begin{array}{c}0.0307 \\
(0.0633)\end{array}$ & $\begin{array}{c}0.122 \\
(6.237)\end{array}$ & $\begin{array}{l}-0.0696 \\
(0.0595)\end{array}$ & $\begin{array}{l}2.684 \\
(2.311)\end{array}$ \\
\hline Booker & $\begin{array}{c}-2.513 * * \\
(1.087)\end{array}$ & $\begin{array}{l}-0.00116 \\
(0.0106)\end{array}$ & $\begin{array}{c}0.534 \\
(5.492)\end{array}$ & $\begin{array}{c}0.0815 * * * \\
(0.0193)\end{array}$ & $\begin{array}{l}-1.134 \\
(3.183)\end{array}$ & $\begin{array}{c}-0.0803 * * * \\
(0.0203)\end{array}$ & $\begin{array}{l}-0.259 \\
(0.383)\end{array}$ \\
\hline Booker*Black & $\begin{array}{l}1.658 * * \\
(0.797)\end{array}$ & $\begin{array}{c}0.0151 * * * \\
(0.00518)\end{array}$ & $\begin{array}{l}6.558^{*} \\
(3.860)\end{array}$ & $\begin{array}{c}-0.0102 \\
(0.00798)\end{array}$ & $\begin{array}{c}6.725 \\
(7.028)\end{array}$ & $\begin{array}{c}-0.00491 \\
(0.00757)\end{array}$ & $\begin{array}{c}0.649 * * * \\
(0.197)\end{array}$ \\
\hline Booker*Hispanic & $\begin{array}{c}0.766 \\
(0.551)\end{array}$ & $\begin{array}{l}0.000747 \\
(0.00454)\end{array}$ & $\begin{array}{l}-0.0243 \\
(3.160)\end{array}$ & $\begin{array}{l}-0.0118 \\
(0.0147)\end{array}$ & $\begin{array}{c}3.987 \\
(3.042)\end{array}$ & $\begin{array}{c}0.0111 \\
(0.0136)\end{array}$ & $\begin{array}{c}0.378 * * * \\
(0.131)\end{array}$ \\
\hline Booker*Other & $\begin{array}{l}-0.231 \\
(0.963)\end{array}$ & $\begin{array}{c}0.00186 \\
(0.00911)\end{array}$ & $\begin{array}{c}5.001 \\
(6.341)\end{array}$ & $\begin{array}{l}-0.00783 \\
(0.0202)\end{array}$ & $\begin{array}{c}1.725 \\
(4.334)\end{array}$ & $\begin{array}{l}0.00597 \\
(0.0186)\end{array}$ & $\begin{array}{l}-0.272 \\
(0.415)\end{array}$ \\
\hline Pre Booker Bush & $\begin{array}{l}1.219 \\
(1.161)\end{array}$ & $\begin{array}{c}0.00324 \\
(0.00614)\end{array}$ & $\begin{array}{l}-10.94^{*} \\
(6.186)\end{array}$ & $\begin{array}{c}-0.0446 * * \\
(0.0198)\end{array}$ & $\begin{array}{l}-4.095 \\
(2.861)\end{array}$ & $\begin{array}{l}0.0414 * \\
(0.0219)\end{array}$ & $\begin{array}{c}0.154 \\
(0.242)\end{array}$ \\
\hline Pre Booker Bush*Black & $\begin{array}{l}2.315 \\
(1.712)\end{array}$ & $\begin{array}{c}0.00512 \\
(0.00988)\end{array}$ & $\begin{array}{l}9.985 \\
(8.224)\end{array}$ & $\begin{array}{l}-0.00139 \\
(0.0176)\end{array}$ & $\begin{array}{c}6.167 \\
(8.236)\end{array}$ & $\begin{array}{l}-0.00373 \\
(0.0192)\end{array}$ & $\begin{array}{c}0.318 \\
(0.263)\end{array}$ \\
\hline Pre Booker Bush*Hispanic & $\begin{array}{l}0.0911 \\
(1.398)\end{array}$ & $\begin{array}{c}0.00169 \\
(0.00617)\end{array}$ & $\begin{array}{c}4.016 \\
(6.225)\end{array}$ & $\begin{array}{c}0.0361 \\
(0.0238)\end{array}$ & $\begin{array}{c}2.602 \\
(2.934)\end{array}$ & $\begin{array}{l}-0.0378 \\
(0.0244)\end{array}$ & $\begin{array}{r}-0.0322 \\
(0.215)\end{array}$ \\
\hline Pre Booker Bush*Other & $\begin{array}{l}-0.567 \\
(2.259)\end{array}$ & $\begin{array}{c}-0.0100 \\
(0.0104)\end{array}$ & $\begin{array}{c}6.193 \\
(18.15)\end{array}$ & $\begin{array}{c}0.0121 \\
(0.0353)\end{array}$ & $\begin{array}{c}3.751 \\
(5.223)\end{array}$ & $\begin{array}{l}-0.00207 \\
(0.0361)\end{array}$ & $\begin{array}{c}0.481 \\
(0.386)\end{array}$ \\
\hline Booker*Pre Booker Bush & $\begin{array}{l}-0.725 \\
(1.241)\end{array}$ & $\begin{array}{c}-0.00357 \\
(0.00741)\end{array}$ & $\begin{array}{c}9.820 \\
(7.513)\end{array}$ & $\begin{array}{c}0.0210 \\
(0.0189)\end{array}$ & $\begin{array}{c}5.753 \\
(3.550)\end{array}$ & $\begin{array}{l}-0.0174 \\
(0.0228)\end{array}$ & $\begin{array}{l}-0.109 \\
(0.318)\end{array}$ \\
\hline Booker*Pre Booker Bush*Black & $\begin{array}{l}-1.375 \\
(1.758)\end{array}$ & $\begin{array}{l}-0.00575 \\
(0.0124)\end{array}$ & $\begin{array}{l}-10.94 \\
(10.18)\end{array}$ & $\begin{array}{l}-0.0141 \\
(0.0193)\end{array}$ & $\begin{array}{l}-6.872 \\
(9.353)\end{array}$ & $\begin{array}{c}0.0198 \\
(0.0214)\end{array}$ & $\begin{array}{l}-0.305 \\
(0.453)\end{array}$ \\
\hline Booker*Pre Booker Bush*Hispanic & $\begin{array}{l}-0.124 \\
(1.433)\end{array}$ & $\begin{array}{l}-0.00171 \\
(0.00765)\end{array}$ & $\begin{array}{l}-5.195 \\
(6.764)\end{array}$ & $\begin{array}{l}-0.0226 \\
(0.0200)\end{array}$ & $\begin{array}{l}-4.572 \\
(3.590)\end{array}$ & $\begin{array}{c}0.0244 \\
(0.0228)\end{array}$ & $\begin{array}{r}-0.0529 \\
(0.297)\end{array}$ \\
\hline Booker*Pre Booker Bush*Other & $\begin{array}{l}1.375 \\
(1.626)\end{array}$ & $\begin{array}{c}0.0108 \\
(0.0135)\end{array}$ & $\begin{array}{l}-0.555 \\
(23.78)\end{array}$ & $\begin{array}{l}-0.0206 \\
(0.0386)\end{array}$ & $\begin{array}{l}-2.776 \\
(7.305)\end{array}$ & $\begin{array}{l}0.00984 \\
(0.0423)\end{array}$ & $\begin{array}{l}-1.020 \\
(0.646)\end{array}$ \\
\hline $\begin{array}{l}\text { Observations } \\
\text { R-squared }\end{array}$ & $\begin{array}{c}214,136 \\
0.784\end{array}$ & $\begin{array}{c}214,136 \\
0.194\end{array}$ & $\begin{array}{c}13,091 \\
0.368\end{array}$ & $\begin{array}{c}214,136 \\
0.244\end{array}$ & $\begin{array}{c}82,432 \\
0.919\end{array}$ & $\begin{array}{c}214,136 \\
0.202\end{array}$ & $\begin{array}{c}118,612 \\
0.985\end{array}$ \\
\hline
\end{tabular}

Notes: Data is from the matched USSC, TRAC, Federal Judicial Center data from 2000-2009 for courts with random assignment, excluding judges who formally retired prior to 2000. All regressions contain controls for offense type, and dummies for each offense level and criminal history combination. Regressions also contain district by sentencing year, and sentencing month fixed effects, and standard errors are clustered at the district level. $* * *=$ significant at 1 percent level, $* *=$ significant at 5 percent level, $*=$ significant at 10 percent level. 
Table A18. Sentencing for Post Booker Judges Comparison to New Judges Pre Booker

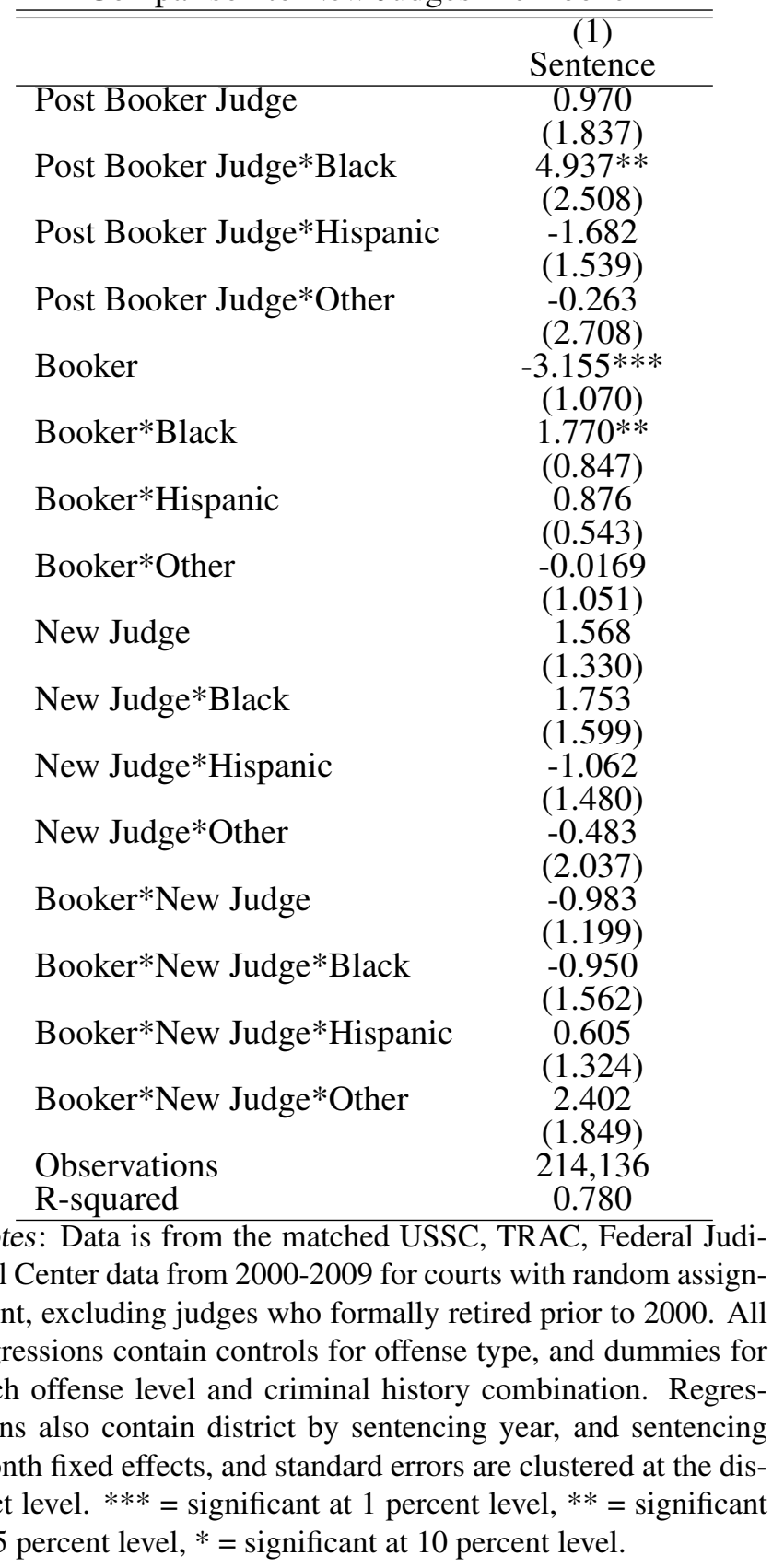


Table A19. Sentencing Patterns Before and After Booker, By Judicial Demographics

\begin{tabular}{|c|c|c|c|c|c|c|c|}
\hline \multicolumn{8}{|c|}{ (2) } \\
\hline & Sentence & Above & Months & Below & Months & Within & Months \\
\hline & & Range & Above & Range & Above & Range & Within \\
\hline Post Booker Judge & $\begin{array}{l}-1.441 \\
(1.759)\end{array}$ & $\begin{array}{c}-0.00562 \\
(0.0114)\end{array}$ & $\begin{array}{c}-0.498 \\
(8.488)\end{array}$ & $\begin{array}{c}0.0136 \\
(0.0174)\end{array}$ & $\begin{array}{l}-2.160 \\
(5.945)\end{array}$ & $\begin{array}{l}-0.00794 \\
(0.0148)\end{array}$ & $\begin{array}{c}-0.754 * * \\
(0.319)\end{array}$ \\
\hline Post Booker Judge*Black & $\begin{array}{l}4.382 * \\
(2.530)\end{array}$ & $\begin{array}{c}0.0202 \\
(0.0144)\end{array}$ & $\begin{array}{c}4.746 \\
(7.207)\end{array}$ & $\begin{array}{r}-0.00394 \\
(0.0236)\end{array}$ & $\begin{array}{c}1.433 \\
(8.284)\end{array}$ & $\begin{array}{l}-0.0162 \\
(0.0198)\end{array}$ & $\begin{array}{l}0.983 * \\
(0.538)\end{array}$ \\
\hline Post Booker Judge*Hispanic & $\begin{array}{l}-0.677 \\
(1.618)\end{array}$ & $\begin{array}{c}0.0157 \\
(0.0227)\end{array}$ & $\begin{array}{l}-6.538 \\
(8.008)\end{array}$ & $\begin{array}{c}0.000139 \\
(0.0306)\end{array}$ & $\begin{array}{l}-2.496 \\
(5.541)\end{array}$ & $\begin{array}{r}-0.0159 \\
(0.0331)\end{array}$ & $\begin{array}{c}0.822 * * \\
(0.366)\end{array}$ \\
\hline Post Booker Judge*Other & $\begin{array}{c}0.561 \\
(2.654)\end{array}$ & $\begin{array}{c}0.0451 \\
(0.0310)\end{array}$ & $\begin{array}{l}-12.61 \\
(12.44)\end{array}$ & $\begin{array}{c}0.0253 \\
(0.0646)\end{array}$ & $\begin{array}{l}-1.288 \\
(6.763)\end{array}$ & $\begin{array}{l}-0.0704 \\
(0.0615)\end{array}$ & $\begin{array}{c}2.613 \\
(2.328)\end{array}$ \\
\hline Booker & $\begin{array}{c}-2.555^{* *} * \\
(1.254)\end{array}$ & $\begin{array}{c}-0.000691 \\
(0.0118)\end{array}$ & $\begin{array}{c}1.446 \\
(6.244)\end{array}$ & $\begin{array}{c}0.0719 * * * \\
(0.0224)\end{array}$ & $\begin{array}{c}0.736 \\
(4.371)\end{array}$ & $\begin{array}{c}-0.0712 * * * * \\
(0.0231)\end{array}$ & $\begin{array}{l}-0.401 \\
(0.397)\end{array}$ \\
\hline Booker*Black & $\begin{array}{c}3.050 * * * * \\
(1.147)\end{array}$ & $\begin{array}{c}0.0117 * * \\
(0.00556)\end{array}$ & $\begin{array}{l}15.03 * * \\
(6.023)\end{array}$ & $\begin{array}{c}-0.0134 \\
(0.0109)\end{array}$ & $\begin{array}{l}-3.143 \\
(8.627)\end{array}$ & $\begin{array}{l}0.00170 \\
(0.0101)\end{array}$ & $\begin{array}{c}0.823 * * \\
(0.389)\end{array}$ \\
\hline Booker*Hispanic & $\begin{array}{c}0.760 \\
(0.831)\end{array}$ & $\begin{array}{c}-0.00167 \\
(0.00569)\end{array}$ & $\begin{array}{l}-0.227 \\
(4.147)\end{array}$ & $\begin{array}{c}-0.00486 \\
(0.0173)\end{array}$ & $\begin{array}{c}2.081 \\
(4.288)\end{array}$ & $\begin{array}{l}0.00653 \\
(0.0156)\end{array}$ & $\begin{array}{l}0.358^{*} \\
(0.204)\end{array}$ \\
\hline Booker*Other & $\begin{array}{l}0.0750 \\
(1.103)\end{array}$ & $\begin{array}{c}0.00327 \\
(0.0116)\end{array}$ & $\begin{array}{c}8.481 \\
(12.74)\end{array}$ & $\begin{array}{l}-0.00508 \\
(0.0286)\end{array}$ & $\begin{array}{l}0.0415 \\
(5.458)\end{array}$ & $\begin{array}{l}0.00182 \\
(0.0245)\end{array}$ & $\begin{array}{c}-0.954 \\
(0.610)\end{array}$ \\
\hline Female Judge & $\begin{array}{l}1.418 \\
(1.027)\end{array}$ & $\begin{array}{c}0.00285 \\
(0.00642)\end{array}$ & $\begin{array}{l}-3.574 \\
(6.059)\end{array}$ & $\begin{array}{l}-0.0110 \\
(0.0135)\end{array}$ & $\begin{array}{c}3.612 \\
(4.705)\end{array}$ & $\begin{array}{l}0.00814 \\
(0.0161)\end{array}$ & $\begin{array}{c}0.328 \\
(0.292)\end{array}$ \\
\hline Female Judge*Black & $\begin{array}{c}0.230 \\
(1.602)\end{array}$ & $\begin{array}{c}0.00242 \\
(0.00911)\end{array}$ & $\begin{array}{c}7.303 \\
(6.260)\end{array}$ & $\begin{array}{c}0.0145 \\
(0.0180)\end{array}$ & $\begin{array}{c}0.445 \\
(12.81)\end{array}$ & $\begin{array}{l}-0.0169 \\
(0.0201)\end{array}$ & $\begin{array}{l}-0.176 \\
(0.368)\end{array}$ \\
\hline Female Judge*Hispanic & $\begin{array}{c}-0.996 \\
(1.214)\end{array}$ & $\begin{array}{c}0.00206 \\
(0.00811)\end{array}$ & $\begin{array}{c}3.262 \\
(6.608)\end{array}$ & $\begin{array}{c}0.000581 \\
(0.0190)\end{array}$ & $\begin{array}{c}2.271 \\
(5.069)\end{array}$ & $\begin{array}{r}-0.00264 \\
(0.0211)\end{array}$ & $\begin{array}{l}-0.333 \\
(0.245)\end{array}$ \\
\hline Female Judge* Other & $\begin{array}{l}-2.031 \\
(1.329)\end{array}$ & $\begin{array}{c}-0.0124 \\
(0.00963)\end{array}$ & $\begin{array}{c}2.331 \\
(9.701)\end{array}$ & $\begin{array}{c}0.00735 \\
(0.0264)\end{array}$ & $\begin{array}{c}-10.92 \\
(7.838)\end{array}$ & $\begin{array}{l}0.00501 \\
(0.0276)\end{array}$ & $\begin{array}{c}-0.875 \\
(0.566)\end{array}$ \\
\hline Female Judge*Booker & $\begin{array}{c}-2.417 * * \\
(0.951)\end{array}$ & $\begin{array}{c}-0.00351 \\
(0.00879)\end{array}$ & $\begin{array}{c}2.032 \\
(6.990)\end{array}$ & $\begin{array}{c}0.0208 \\
(0.0142)\end{array}$ & $\begin{array}{c}3.671 \\
(4.586)\end{array}$ & $\begin{array}{l}-0.0173 \\
(0.0181)\end{array}$ & $\begin{array}{l}-0.226 \\
(0.380)\end{array}$ \\
\hline Female Judge*Booker*Black & $\begin{array}{r}-0.0853 \\
(1.643)\end{array}$ & $\begin{array}{c}-0.00367 \\
(0.0121)\end{array}$ & $\begin{array}{l}-10.97 \\
(7.743)\end{array}$ & $\begin{array}{l}-0.0221 \\
(0.0214)\end{array}$ & $\begin{array}{c}-7.574 \\
(12.88)\end{array}$ & $\begin{array}{c}0.0257 \\
(0.0256)\end{array}$ & $\begin{array}{c}-0.333 \\
(0.452)\end{array}$ \\
\hline Female Judge*Booker*Hispanic & $\begin{array}{c}1.530 \\
(0.982)\end{array}$ & $\begin{array}{c}-0.000806 \\
(0.0105)\end{array}$ & $\begin{array}{c}0.134 \\
(7.266)\end{array}$ & $\begin{array}{c}-0.00556 \\
(0.0161)\end{array}$ & $\begin{array}{c}-9.481 * \\
(5.520)\end{array}$ & $\begin{array}{l}0.00637 \\
(0.0202)\end{array}$ & $\begin{array}{c}0.372 \\
(0.349)\end{array}$ \\
\hline Female Judge*Booker*Other & $\begin{array}{l}1.599 \\
(2.263)\end{array}$ & $\begin{array}{c}0.0127 \\
(0.0176)\end{array}$ & $\begin{array}{c}8.924 \\
(15.01)\end{array}$ & $\begin{array}{l}-0.0137 \\
(0.0316)\end{array}$ & $\begin{array}{c}7.373 \\
(9.548)\end{array}$ & $\begin{array}{l}0.00104 \\
(0.0304)\end{array}$ & $\begin{array}{c}0.325 \\
(0.734)\end{array}$ \\
\hline Black Judge & $\begin{array}{l}-0.331 \\
(0.793)\end{array}$ & $\begin{array}{l}-0.00651 \\
(0.00758)\end{array}$ & $\begin{array}{l}-5.803 \\
(4.309)\end{array}$ & $\begin{array}{l}-0.0142 \\
(0.0127)\end{array}$ & $\begin{array}{c}-9.873 \\
(11.31)\end{array}$ & $\begin{array}{c}0.0207 \\
(0.0158)\end{array}$ & $\begin{array}{c}0.0118 \\
(0.217)\end{array}$ \\
\hline Black Judge*Black & $\begin{array}{l}1.445 \\
(1.322)\end{array}$ & $\begin{array}{c}0.00771 \\
(0.00815)\end{array}$ & $\begin{array}{l}13.53 * * \\
(5.807)\end{array}$ & $\begin{array}{l}0.00716 \\
(0.0137)\end{array}$ & $\begin{array}{l}-11.16 \\
(21.36)\end{array}$ & $\begin{array}{l}-0.0149 \\
(0.0164)\end{array}$ & $\begin{array}{c}0.245 \\
(0.327)\end{array}$ \\
\hline Black Judge*Hispanic & $\begin{array}{l}-0.405 \\
(1.013)\end{array}$ & $\begin{array}{c}-0.00252 \\
(0.00967)\end{array}$ & $\begin{array}{c}1.355 \\
(5.835)\end{array}$ & $\begin{array}{c}0.0378 \\
(0.0241)\end{array}$ & $\begin{array}{c}16.00 \\
(11.44)\end{array}$ & $\begin{array}{l}-0.0353 \\
(0.0275)\end{array}$ & $\begin{array}{l}0.0286 \\
(0.296)\end{array}$ \\
\hline Black Judge*Other & 1.587 & -0.00655 & $23.21^{*}$ & $-0.0576 * *$ & 2.950 & $0.0641 *$ & -0.0150 \\
\hline
\end{tabular}


Black Judge*Booker

Black Judge*Booker*Black

Black Judge*Booker*Hispanic

Black Judge*Booker*Other

Democratic Judge

Democratic Judge*Black

Democratic Judge*Hispanic

Democratic Judge* Other

Democratic Judge*Booker

Democratic Judge*Booker*Black

\begin{tabular}{|c|c|c|c|c|c|c|}
\hline (1.783) & $(0.0147)$ & (11.89) & $(0.0269)$ & (12.03) & $(0.0335)$ & $(0.594)$ \\
\hline-0.615 & 0.00244 & 6.650 & 0.0269 & 10.27 & -0.0294 & -0.0790 \\
\hline (1.278) & $(0.0103)$ & (4.678) & $(0.0168)$ & $(10.52)$ & $(0.0208)$ & $(0.317)$ \\
\hline-1.916 & -0.00161 & $-15.77 * *$ & -0.00492 & 11.38 & 0.00653 & -0.361 \\
\hline (1.669) & $(0.00974)$ & $(6.071)$ & $(0.0205)$ & (21.02) & $(0.0226)$ & $(0.503)$ \\
\hline-0.543 & 0.00172 & -4.824 & -0.0388 & -16.28 & 0.0371 & -0.224 \\
\hline$(1.256)$ & $(0.0112)$ & $(6.605)$ & $(0.0266)$ & (10.63) & $(0.0284)$ & $(0.414)$ \\
\hline-1.470 & 0.0198 & $-21.87 *$ & $0.107 * * *$ & -8.142 & $-0.127 * * *$ & 0.433 \\
\hline (1.890) & (0.0188) & (13.01) & $(0.0345)$ & (12.33) & $(0.0401)$ & $(0.746)$ \\
\hline-0.969 & 0.00433 & -0.903 & $0.0210 *$ & 4.061 & $-0.0254 * *$ & $-0.418 *$ \\
\hline$(0.820)$ & $(0.00488)$ & $(4.072)$ & $(0.0109)$ & $(5.135)$ & $(0.0112)$ & $(0.218)$ \\
\hline-0.658 & -0.00890 & 6.518 & 0.0101 & -6.783 & -0.00123 & -0.382 \\
\hline (1.055) & $(0.00559)$ & (5.918) & $(0.00992)$ & $(9.201)$ & $(0.0111)$ & $(0.296)$ \\
\hline 0.526 & -0.00411 & 1.370 & -0.00607 & -7.242 & 0.0102 & 0.218 \\
\hline (1.007) & $(0.00555)$ & (4.969) & $(0.0125)$ & $(5.873)$ & $(0.0114)$ & $(0.184)$ \\
\hline 0.632 & 0.00936 & 3.612 & 0.0129 & -0.615 & -0.0223 & $-0.799 *$ \\
\hline (1.218) & $(0.00895)$ & $(8.762)$ & $(0.0246)$ & $(6.925)$ & $(0.0239)$ & $(0.404)$ \\
\hline 0.176 & -0.00773 & 0.180 & 0.0142 & -3.031 & -0.00642 & $0.447 *$ \\
\hline (1.101) & $(0.00694)$ & $(4.848)$ & $(0.0134)$ & $(5.629)$ & $(0.0146)$ & $(0.246)$ \\
\hline-1.723 & 0.00920 & -10.39 & 0.00429 & 8.125 & -0.0135 & -0.154 \\
\hline$(1.410)$ & $(0.00748)$ & $(6.716)$ & $(0.0150)$ & $(8.599)$ & $(0.0157)$ & $(0.411)$ \\
\hline-0.421 & 0.00878 & -0.857 & -0.00946 & 6.917 & 0.000684 & -0.261 \\
\hline$(1.142)$ & $(0.00741)$ & (5.687) & $(0.0140)$ & $(6.440)$ & $(0.0141)$ & $(0.239)$ \\
\hline-0.647 & 0.000605 & -2.612 & -0.0285 & 0.319 & 0.0279 & 0.194 \\
\hline$(1.785)$ & $(0.0113)$ & $(13.02)$ & $(0.0327)$ & $(10.31)$ & $(0.0338)$ & $(0.647)$ \\
\hline-0.546 & -0.00326 & -4.842 & 0.00841 & 3.989 & -0.00515 & 0.206 \\
\hline$(0.761)$ & $(0.00499)$ & $(4.541)$ & $(0.0125)$ & $(9.640)$ & $(0.0127)$ & $(0.203)$ \\
\hline 1.575 & -0.00139 & 12.08 & -0.00217 & -26.72 & 0.00356 & 0.0770 \\
\hline$(1.260)$ & $(0.00632)$ & (7.558) & $(0.0113)$ & $(20.37)$ & $(0.0124)$ & $(0.351)$ \\
\hline 0.138 & 0.00254 & 3.825 & -0.0147 & -5.434 & 0.0121 & -0.210 \\
\hline$(0.791)$ & $(0.00490)$ & (5.218) & $(0.0166)$ & (9.774) & $(0.0170)$ & $(0.191)$ \\
\hline 0.421 & $0.0256 *$ & 4.107 & -0.0133 & -8.988 & -0.0123 & $-1.301 * *$ \\
\hline (1.349) & $(0.0140)$ & $(9.500)$ & $(0.0251)$ & $(13.36)$ & $(0.0267)$ & $(0.531)$ \\
\hline 0.645 & 0.0132 & 2.289 & 0.00772 & -1.550 & -0.0209 & -0.277 \\
\hline (1.197) & $(0.00931)$ & $(5.505)$ & $(0.0157)$ & (9.094) & $(0.0146)$ & $(0.292)$ \\
\hline-2.228 & -0.00519 & -10.61 & 0.00535 & 22.34 & -0.000152 & -0.300 \\
\hline$(1.741)$ & $(0.0114)$ & $(8.665)$ & $(0.0184)$ & (18.68) & $(0.0171)$ & $(0.489)$ \\
\hline-0.0513 & -0.0108 & 3.226 & -0.00771 & 2.848 & 0.0185 & 0.346 \\
\hline$(1.100)$ & $(0.00869)$ & (7.071) & $(0.0179)$ & $(9.145)$ & $(0.0161)$ & $(0.286)$ \\
\hline 2.699 & -0.0129 & -14.23 & -0.0461 & 5.441 & 0.0591 & 1.052 \\
\hline$(2.648)$ & $(0.0236)$ & (15.35) & $(0.0351)$ & (13.52) & $(0.0369)$ & $(0.984)$ \\
\hline 214,136 & 214,136 & 13,091 & 214,136 & 82,432 & 214,136 & 118,612 \\
\hline 0.784 & 0.194 & 0.369 & 0.245 & 0.919 & 0.203 & 0.985 \\
\hline
\end{tabular}


Notes: Data is from the matched USSC, TRAC, Federal Judicial Center data from 2000-2009 for courts with random assignment, excluding judges who formally retired prior to 2000. All regressions contain controls for offense type, and dummies for each offense level and criminal history combination. Regressions also contain district by sentencing year, and sentencing month fixed effects, and standard errors are clustered at the district level. $* * *=$ significant at 1 percent level, $* *=$ significant at 5 percent level, $*=$ significant at 10 percent level. 


\section{REFERENCES}

98th Congress 1st Session. 1983. Senate Report No. 98-225. 98th Congress 1st Session.

Abrams, David S., Marianne Bertrand, and Sendhil Mullainathan. 2012. "Do Judges Vary in Their Treatment of Race?" Journal of Legal Studies 41:347-383.

Alschuler, Albert W. 1978. "Sentencing Reform and Prosecutorial Power: A Critique of Recent Proposals for "Fixed'" and "Presumptive" Sentencing." University of Pennsylvania Law Review 126:550-577.

American Friends Service Committee. 1971. Struggle for Justice: A Report on Crime and Punishment in America. Hill \& Wang.

Anderson, James M., Jeffrey R. Kling, and Kate Stith. 1999. "Measuring Interjudge Sentencing Disparity: Before and After the Federal Sentencing Guidelines." Journal of Law and Economics 42:271-307.

Anwar, Shamena, Patrick Bayer, and Randi Hjalmarsson. 2012. "The Impact of Jury Race in Criminal Trials." Quarterly Journal of Economics 127:1017-1055.

Austin, William, and Thomas A. Williams III. 1977. "A Survey of Judges' Responses to Simulated Legal Cases: Research Note on Sentencing Disparity." Journal of Criminal Law and Criminology 69 (2): 306-310 (June).

Autor, David H., and Susan N. Houseman. 2010. "Do Temporary-Help Jobs Improve Labor Market Outcomes for Low-Skilled Workers? Evidence from 'Work First'." American Economic Journal: Applied Economics 2 (3): 96-128 (July).

Berman, Douglas A. 2005. "Foreword: Beyond Blakely and Booker: Pondering Modern Sentencing Process." Journal of Criminal Law and Criminology 95:653-689.

Fischman, Joshua B., and Max M. Schanzenbach. 2011. "Do Standards of Review Matter? The Case of Federal Criminal Sentencing." Journal of Legal Studies 40:405-437.

_. 2012. "Racial Disparities under the Federal Sentencing Guidelines: The Role of Judicial Discretion and Mandatory Minimums." Journal of Empirical Legal Studies 9:729-764.

Frankel, Marvin E. 1973. Criminal Sentences: Law Without Order. New York: Hill \& Wang.

Freeborn, Beth A., and Monica E. Hartmann. 2010. "Judicial Discretion and Sentencing Behavior: Did the Feeney Amendment Rein in District Judges?" Journal of Empirical Legal Studies 7:355-378.

Freed, Daniel J. 1992. "Federal Sentencing in the Wake of the Guidelines: Unacceptable Limits on the Discretion of Sentencers." Yale Law Journal 101:1681-1754.

Gennaioli, Nicola, and Andrei Shleifer. 2008. “Judicial Fact Discretion.” Journal of Legal Studies $37: 1-35$.

Gertner, Nancy. 2006. "What Yogi Berra Teaches About Post-Booker Sentencing." Yale Law Journal Pocket Part 115:137-141.

Hofer, Paul J., Kevin R. Blackwell, and R. Barry Ruback. 1999. "The Effect of the Federal Sentencing Guidelines on Inter-Judge Sentencing Disparity." Journal of Criminal Law and Criminology 90:239-321. 
Kuziemko, Ilyana. 2013. "How Should Inmates Be Released From Prison? An Assessment of Parole Versus Fixed Sentence Regimes." Quarterly Journal of Economics 128:371-424.

Mustard, David B. 2001. "Racial, Ethnic, and Gender Disparities in Sentencing: Evidence from the U.S. Federal Courts." Journal of Law and Economics 44:258-314.

Nagel, Ilene H., and Steven J. Schulhofer. 1992. "A Tale of Three Cities: An Empirical Study of Charging and Bargaining Practices Under the Sentencing Guidelines." Southern California Law Review 66:501-566.

Posner, Richard A. 2005. "Judicial Behavior and Performance: An Economic Approach.” Florida State University Law Review 32:1259-1279.

Rehavi, M. Marit, and Sonja B. Starr. 2012, January. "Racial Disparity in Federal Criminal Charging and its Sentencing Consequences." University of Michigan Law \& Economics, Empirical Legal Studies Center Paper No. 12-002.

Schanzenbach, Max M. 2005. "Racial and Sex Disparities in Prison Sentences: The Effect of District-Level Judicial Demographics." Journal of Legal Studies 34 (1): 57-92.

Schanzenbach, Max M., and Emerson H. Tiller. 2007. "Strategic Judging Under the United States Sentencing Guidelines: Positive Political Theory and Evidence." Journal of Law, Economics, and Organization 23 (1): 24-56.

_. 2008. "Reviewing the Sentencing Guidelines: Judicial Politics, Empirical Evidence, and Reform." University of Chicago Law Review 75:715-760.

Scott, Ryan W. 2010. "Inter-Judge Sentencing Disparity After Booker: A First Look." Stanford Law Review 63 (1): 1-66 (December).

Sessions, III, William K. 2011. "At the Crossroads of the Three Branches: The U.S. Sentencing Commission's Attempts to Achieve Sentencing Reform in the Midst of Inter-Branch Power Struggles." The Journal of Law and Politics 26:305-357.

Starr, Sonja B., and M. Marit Rehavi. 2012. "Racial Disparity in the Criminal Justice Process: Prosecutors, Judges, and the Effects of United States v. Booker." University of Michigan Law \& Economics, Research Paper No. 12-021.

Stith, Kate. 2008. "The Arc of the Pendulum: Judges, Prosecutors, and the Exercise of Discretion." Yale Law Journal 117:1420-1497.

Stith, Kate, and Jose A. Cabranes. 1998. Fear of Judging: Sentencing Guidelines in the Federal Courts. The University of Chicago Press.

Tonry, Michael. 2005. "Obsolescence and Immanence in Penal Theory and Policy." Columbia Law Review 105 (4): 1233-1275 (May).

Ulmer, Jeffery T., Michael T. Light, and John H. Kramer. 2011. "Racial Disparity in the Wake of the Booker/Fanfan Decision: An Alternative Analysis to the USSC's 2010 Report." Criminology and Public Policy 10 (4): 1077-1118.

United States Sentencing Commission. 2004, May. Measuring Recividism: The Criminal History Computation of the Federal Sentencing Guidelines. Washington, DC: United States Sentencing Commission. 
. 2006. Final Report on the Impact of United States v. Booker on Federal Sentencing. Washington, DC: United States Sentencing Commission.

- 2010. Demographic Differences in Federal Sentencing Practices: An Update of the Booker Report's Multivariate Regression Analysis. Washington, DC: United States Sentencing Commission.

— 2011, October. Report to Congress: Mandatory Minimum Penalties in the Federal Criminal Justice System. Washington, DC: United States Sentencing Commission.

Welch, Susan, Michael Combs, and John Gruhl. 1988. "Do Black Judges Make a Difference?" American Journal of Political Science 32:126-136.

Wheeler, Stanton, Kenneth Mann, and Austin Sarat. 1988. Sitting in Judgment: The Sentencing of White-Collar Criminals. Yale University Press. 
Table I. Summary Statistics

\begin{tabular}{lccccc}
\hline \hline & Panel A. USSC Data, 1994-2009 & & \\
\cline { 2 - 6 } Variable & Obs & Mean & Std. Dev. & Min & Max \\
\hline Incarceration & 853008 & 0.833 & 0.373 & 0 & 1 \\
Probation Length in Months & 142627 & 29.858 & 22.238 & 0 & 997 \\
Sentence Length in Months & 847227 & 49.290 & 65.108 & 0 & 985 \\
Statutory Minimum Applied & 853561 & 0.299 & 0.458 & 0 & 1 \\
Settled by Trial & 665073 & 0.044 & 0.205 & 0 & 1 \\
Supervised Release in Months & 852701 & 38.490 & 59.829 & 0 & 999 \\
White & 852875 & 0.318 & 0.466 & 0 & 1 \\
Black & 852875 & 0.261 & 0.439 & 0 & 1 \\
Hispanic & 852875 & 0.379 & 0.485 & 0 & 1 \\
Non US Citizen & 852990 & 0.320 & 0.467 & 0 & 1 \\
Number of Dependents & 854992 & 1.598 & 2.023 & 0 & 98 \\
Less Than High School & 842099 & 0.461 & 0.498 & 0 & 1 \\
Male & 854611 & 0.859 & 0.348 & 0 & 1 \\
Age & 854992 & 34.696 & 10.798 & 16 & 98 \\
Criminal History Indicator & 664422 & 0.746 & 0.435 & 0 & 1 \\
Drug Trafficking Offense & 854992 & 0.388 & 0.487 & 0 & 1 \\
Immigration Offense & 854992 & 0.179 & 0.383 & 0 & 1 \\
Fraud Offense & 854992 & 0.113 & 0.317 & 0 & 1 \\
Firearm Offense & 854992 & 0.092 & 0.289 & 0 & 1 \\
Criminal History Category (1-6) & 854992 & 2.361 & 1.699 & 1 & 6 \\
Final Offense Level (1-43) & 854992 & 18.841 & 8.961 & 1 & 43 \\
\hline
\end{tabular}

Panel B. Judge Matched Data, 2000-2009

\begin{tabular}{lccccc} 
Variable & Obs & Mean & Std. Dev. & Min & Max \\
\hline Incarceration & 643990 & 0.839 & 0.368 & 0 & 1 \\
Probation Length in Months & 103822 & 25.345 & 22.065 & 0 & 120 \\
Sentence Length in Months & 641986 & 45.920 & 59.871 & 0 & 985 \\
Statutory Minimum Applied & 633235 & 0.282 & 0.450 & 0 & 1 \\
Settled by Trial & 643990 & 0.035 & 0.183 & 0 & 1 \\
Supervised Release in Months & 643347 & 38.264 & 61.330 & 0 & 999 \\
White & 626500 & 0.294 & 0.456 & 0 & 1 \\
Black & 626500 & 0.234 & 0.423 & 0 & 1 \\
Hispanic & 626500 & 0.436 & 0.496 & 0 & 1 \\
Non US Citizen & 633942 & 0.384 & 0.486 & 0 & 1 \\
Number of Dependents & 595781 & 1.616 & 1.739 & 0 & 82 \\
Less Than High School & 599619 & 0.489 & 0.499 & 0 & 1 \\
Male & 636641 & 0.867 & 0.340 & 0 & 1 \\
Age & 638530 & 34.548 & 10.644 & 16 & 97 \\
Criminal History Indicator & 632772 & 0.749 & 0.434 & 0 & 1 \\
Drug Trafficking Offense & 643990 & 0.369 & 0.482 & 0 & 1 \\
Immigration Offense & 643990 & 0.251 & 0.433 & 0 & 1 \\
Fraud Offense & 643990 & 0.101 & 0.301 & 0 & 1 \\
Firearm Offense & 643990 & 0.096 & 0.295 & 0 & 1 \\
Criminal History Category (1-6) & 643990 & 2.416 & 1.705 & 1 & 6 \\
Final Offense Level (1-43) & 643990 & 18.451 & 8.625 & 1 & 43 \\
Male Judge & 643990 & 0.807 & .395 & 0 & 1 \\
White Judge & 643990 & 0.767 & .423 & 0 & 1 \\
Black Judge & 643990 & 0.083 & .275 & 0 & 1 \\
Hispanic Judge & 643990 & 0.140 & .347 & 0 & 1 \\
Democratic Judge & 643990 & 0.437 & .496 & 0 & 1 \\
\hline
\end{tabular}

Notes: Panel A is from the USSC data from 1994-2009. Panel B is from the USSC, TRAC, and Federal Judicial Center matched data from 2000-2009. 
Table II. Sentence Length in Months

\begin{tabular}{|c|c|c|c|c|c|}
\hline & (1) & $(2)$ & (3) & $(4)$ & $\overline{(5)}$ \\
\hline & Sentence & Sentence & Sentence & Sentence & Sentence \\
\hline Booker*Black & $2.373 * * *$ & $1.653^{* * * *}$ & $1.343^{* *}$ & $1.639 * *$ & $1.642 * *$ \\
\hline & $(0.595)$ & $(0.524)$ & $(0.617)$ & $(0.690)$ & $(0.689)$ \\
\hline Booker*Hispanic & $1.687 * * *$ & $1.559 * * *$ & $1.112 * *$ & $1.098 * *$ & $1.113^{* *}$ \\
\hline & $(0.446)$ & $(0.547)$ & $(0.499)$ & $(0.539)$ & $(0.539)$ \\
\hline Booker*Other & $\begin{array}{c}2.711 * * * \\
(0.986)\end{array}$ & $\begin{array}{c}2.053 * * \\
(1.021)\end{array}$ & $\begin{array}{c}2.295 * * \\
(1.113)\end{array}$ & $\begin{array}{l}-0.168 \\
(1.235)\end{array}$ & $\begin{array}{l}-0.105 \\
(1.229)\end{array}$ \\
\hline Black & $2.638 * * *$ & $2.485 * * *$ & $2.639 * * *$ & $3.185 * * *$ & $3.188 * * *$ \\
\hline & $(0.363)$ & $(0.411)$ & $(0.363)$ & $(0.591)$ & $(0.591)$ \\
\hline Hispanic & $\begin{array}{l}0.878^{*} \\
(0.461)\end{array}$ & $\begin{array}{c}0.850^{*} \\
(0.463)\end{array}$ & $\begin{array}{l}0.877 * \\
(0.461)\end{array}$ & $\begin{array}{l}1.308 * * \\
(0.524)\end{array}$ & $\begin{array}{l}1.306 * * \\
(0.522)\end{array}$ \\
\hline Other & $\begin{array}{c}1.061 \\
(1.092)\end{array}$ & $\begin{array}{c}0.903 \\
(1.271)\end{array}$ & $\begin{array}{l}1.057 \\
(1.092)\end{array}$ & $\begin{array}{c}3.177 * * * \\
(1.055)\end{array}$ & $\begin{array}{c}3.142 * * * \\
(1.050)\end{array}$ \\
\hline Booker & $\begin{array}{c}-3.144 * * * \\
(1.010)\end{array}$ & $\begin{array}{c}-2.840 * * * \\
(1.077)\end{array}$ & $\begin{array}{c}-2.656 * * * \\
(0.995)\end{array}$ & $\begin{array}{c}-2.593 * * \\
(1.129)\end{array}$ & $\begin{array}{c}-3.671 * * * \\
(1.323)\end{array}$ \\
\hline Non US Citizen & $\begin{array}{c}1.466 * * * \\
(0.450)\end{array}$ & $\begin{array}{c}1.470 * * * \\
(0.452)\end{array}$ & $\begin{array}{c}1.472 * * * \\
(0.450)\end{array}$ & $\begin{array}{c}1.479 * * * \\
(0.452)\end{array}$ & $\begin{array}{c}1.478 * * * \\
(0.450)\end{array}$ \\
\hline HS Grad & $\begin{array}{c}-0.554 * * * * \\
(0.185)\end{array}$ & $\begin{array}{c}-0.554 * * * * \\
(0.185)\end{array}$ & $\begin{array}{c}-0.555^{* * * *} \\
(0.185)\end{array}$ & $\begin{array}{c}-0.554 * * * * \\
(0.185)\end{array}$ & $\begin{array}{c}-0.546^{* * * *} \\
(0.185)\end{array}$ \\
\hline Some College & $\begin{array}{c}-1.633^{* * * *} * \\
(0.180)\end{array}$ & $\begin{array}{c}-1.631^{* * * *} \\
(0.181)\end{array}$ & $\begin{array}{c}-1.633^{* * * *} * \\
(0.180)\end{array}$ & $\begin{array}{c}-1.633^{* * * *} \\
(0.180)\end{array}$ & $\begin{array}{c}-1.627 * * * \\
(0.180)\end{array}$ \\
\hline College Grad & $\begin{array}{c}-1.896^{* * * *} \\
(0.235)\end{array}$ & $\begin{array}{c}-1.897 * * * \\
(0.235)\end{array}$ & $\begin{array}{c}-1.897 * * * \\
(0.235)\end{array}$ & $\begin{array}{c}-1.900 * * * \\
(0.235)\end{array}$ & $\begin{array}{c}-1.893 * * * \\
(0.235)\end{array}$ \\
\hline \# Dependents & $\begin{array}{c}-0.150 * * * \\
(0.0440)\end{array}$ & $\begin{array}{c}-0.150 * * * \\
(0.0440)\end{array}$ & $\begin{array}{c}-0.150 * * * \\
(0.0440)\end{array}$ & $\begin{array}{c}-0.150 * * * \\
(0.0441)\end{array}$ & $\begin{array}{c}-0.150 * * * \\
(0.0439)\end{array}$ \\
\hline Female & $\begin{array}{c}-5.388 * * * \\
(0.502)\end{array}$ & $\begin{array}{c}-5.387 * * * * \\
(0.502)\end{array}$ & $\begin{array}{c}-5.385^{* * * *} \\
(0.501)\end{array}$ & $\begin{array}{c}-5.386 * * * \\
(0.501)\end{array}$ & $\begin{array}{c}-5.385 * * * \\
(0.501)\end{array}$ \\
\hline Age & $\begin{array}{c}0.149 * * * \\
(0.0384)\end{array}$ & $\begin{array}{c}0.148 * * * \\
(0.0386)\end{array}$ & $\begin{array}{c}0.148 * * * \\
(0.0384)\end{array}$ & $\begin{array}{c}0.147 * * * \\
(0.0386)\end{array}$ & $\begin{array}{c}0.147 * * * \\
(0.0385)\end{array}$ \\
\hline $\mathrm{Age}^{2}$ & $\begin{array}{c}-0.00147 * * * \\
(0.000429)\end{array}$ & $\begin{array}{c}-0.00146 * * * \\
(0.000430)\end{array}$ & $\begin{array}{c}-0.00146 * * * \\
(0.000429)\end{array}$ & $\begin{array}{c}-0.00145^{* * * *} * \\
(0.000431)\end{array}$ & $\begin{array}{c}-0.00145 * * * \\
(0.000429)\end{array}$ \\
\hline Mandatory Min & $\begin{array}{c}23.15 * * * \\
(1.752)\end{array}$ & $\begin{array}{c}23.15 * * * \\
(1.752)\end{array}$ & $\begin{array}{c}23.14 * * * \\
(1.751)\end{array}$ & $\begin{array}{c}23.15 * * * \\
(1.752)\end{array}$ & $\begin{array}{c}23.15 * * * \\
(1.752)\end{array}$ \\
\hline RGK & & & $\begin{array}{c}-1.954 * * * \\
(0.570)\end{array}$ & & \\
\hline RGK *Black & & & $\begin{array}{c}2.112 * * * \\
(0.616)\end{array}$ & & \\
\hline RGK*Hispanic & & & $1.198 * *$ & & \\
\hline RGK $*$ Other & & & $\begin{array}{c}0.871 \\
(1.037)\end{array}$ & & \\
\hline Race*PROTECT? & No & Yes & No & No & No \\
\hline Race*RGK? & No & No & Yes & No & No \\
\hline Race Trends? & No & No & No & Yes & Yes \\
\hline Year*Month FE? & No & No & No & No & Yes \\
\hline Observations & 679,159 & 679,159 & 679,159 & 679,159 & 679,159 \\
\hline R-squared & 0.741 & 0.741 & 0.741 & 0.741 & 0.741 \\
\hline
\end{tabular}

Notes: Data is from the USSC from 1994-2009. All regressions contain controls for offense type, and dummies for each offense level and criminal history combination. Regressions also contain district by sentencing year, and sentencing month fixed effects, and standard errors are clustered at the district level. $* * *=$ significant at 1 percent level, $* *=$ significant at 5 percent level, $*=$ significant at 10 percent level. 
Table III. Sentencing Departures from the Guidelines

\begin{tabular}{|c|c|c|c|c|c|c|c|}
\hline & $\begin{array}{c}(1) \\
\text { Sentence }\end{array}$ & $\begin{array}{c}(2) \\
\text { Above } \\
\text { Range }\end{array}$ & $\begin{array}{c}(3) \\
\text { Months } \\
\text { Above }\end{array}$ & $\begin{array}{l}(4) \\
\text { Below } \\
\text { Range }\end{array}$ & $\begin{array}{c}(5) \\
\text { Months } \\
\text { Below }\end{array}$ & $\begin{array}{c}(6) \\
\text { Within } \\
\text { Range }\end{array}$ & $\begin{array}{c}(7) \\
\text { Months } \\
\text { Within }\end{array}$ \\
\hline Booker*Black & $1.639 * *$ & $0.0186^{* * * *}$ & $\begin{array}{l}-0.395 \\
(3255)\end{array}$ & $-0.0161^{* *} *$ & $\begin{array}{l}-10.74 \\
(6.663)\end{array}$ & $\begin{array}{l}-0.00247 \\
(0.00624)\end{array}$ & $0.879 * * *$ \\
\hline Booker*Hispanic & $\begin{array}{c}1.098 * * \\
(0.539)\end{array}$ & $\begin{array}{l}0.00694 * \\
(0.00414)\end{array}$ & $\begin{array}{c}4.562 \\
(3.083)\end{array}$ & $\begin{array}{c}0.0110 \\
(0.0111)\end{array}$ & $\begin{array}{c}0.854 \\
(4.852)\end{array}$ & $\begin{array}{l}-0.0179 * \\
(0.00949)\end{array}$ & $\begin{array}{l}0.260^{*} \\
(0.145)\end{array}$ \\
\hline Booke & $\begin{array}{l}-0.168 \\
(1.235)\end{array}$ & $\begin{array}{l}-0.00503 \\
(0.00592)\end{array}$ & $\begin{array}{l}-0.274 \\
(7.719)\end{array}$ & $\begin{array}{c}0.0226 \\
(0.0148)\end{array}$ & $\begin{array}{c}-3.812 \\
(9.318)\end{array}$ & $\begin{array}{l}-0.0176 \\
(0.0153)\end{array}$ & $\begin{array}{l}-0.149 \\
(0.392)\end{array}$ \\
\hline Black & $\begin{array}{c}3.185 * * * \\
(0.591)\end{array}$ & $\begin{array}{c}0.00132 \\
(0.00312)\end{array}$ & $\begin{array}{l}1.981 \\
(2.508)\end{array}$ & $\begin{array}{c}-0.0541 * * * * \\
(0.00709)\end{array}$ & $\begin{array}{c}4.134 \\
(4.781)\end{array}$ & $\begin{array}{c}0.0527 * * * \\
(0.00723)\end{array}$ & $\begin{array}{c}-0.358^{* * *} * \\
(0.116)\end{array}$ \\
\hline Hispanic & $\begin{array}{c}1.308 * * \\
(0.524)\end{array}$ & $\begin{array}{c}-0.00998 * * * \\
(0.00270)\end{array}$ & $\begin{array}{c}-5.831 * * \\
(2.226)\end{array}$ & $\begin{array}{c}-0.0658 * * * \\
(0.00952)\end{array}$ & $\begin{array}{c}-0.311 \\
(3.917)\end{array}$ & $\begin{array}{l}0.0757 * * * \\
(0.00947)\end{array}$ & $\begin{array}{l}0.0262 \\
(0.124)\end{array}$ \\
\hline Other & $\begin{array}{c}3.177 * * * \\
(1.055)\end{array}$ & $\begin{array}{c}0.0151 * * * \\
(0.00471)\end{array}$ & $\begin{array}{l}4.535 \\
(5.593)\end{array}$ & $\begin{array}{c}-0.0667 * * * \\
(0.0242)\end{array}$ & $\begin{array}{c}1.999 \\
(6.727)\end{array}$ & $\begin{array}{c}0.0516^{* *} \\
(0.0240)\end{array}$ & $\begin{array}{c}0.291 \\
(0.232)\end{array}$ \\
\hline Booker & $\begin{array}{c}-2.593 * * \\
(1.129)\end{array}$ & $\begin{array}{c}0.00473 \\
(0.00764)\end{array}$ & $\begin{array}{c}1.460 \\
(4.447)\end{array}$ & $\begin{array}{c}0.0892 * * * \\
(0.0141)\end{array}$ & $\begin{array}{l}13.58 * * \\
(5.247)\end{array}$ & $\begin{array}{c}-0.0940 * * * \\
(0.0140)\end{array}$ & $\begin{array}{l}-0.230 \\
(0.280)\end{array}$ \\
\hline $\begin{array}{l}\text { Race Trends? } \\
\text { Observations }\end{array}$ & $\begin{array}{c}\text { Yes } \\
679.159\end{array}$ & $\begin{array}{c}\text { Yes } \\
679.159\end{array}$ & $\begin{array}{c}\text { Yes } \\
41.478\end{array}$ & $\begin{array}{c}\text { Yes } \\
679.159\end{array}$ & $\begin{array}{c}\text { Yes } \\
255.776\end{array}$ & $\begin{array}{c}\text { Yes } \\
679.159\end{array}$ & $\begin{array}{c}\text { Yes } \\
381901\end{array}$ \\
\hline R-squared & 0.741 & 0.168 & 0.239 & 0.193 & 0.727 & 0.164 & 0.981 \\
\hline
\end{tabular}

Notes: Data is from the USSC from 1994-2009. All regressions contain controls for offense type, and dummies for each offense level and criminal history combination. Regressions also contain district by sentencing year, and sentencing month fixed effects, and standard errors are clustered at the district level. $* * *=$ significant at 1 percent level, $* *=$ significant at 5 percent level, $*=$ significant at 10 percent level. 
Table IV. Disparities in Sentence Length by Other Characteristics

\begin{tabular}{|c|c|c|c|c|}
\hline & (1) & (2) & (3) & (4) \\
\hline & Sentence & Sentence & Sentence & Sentence \\
\hline Booker*Black & $2.373^{* * *}$ & $2.024 * * *$ & $1.680 * * *$ & $1.326^{* * *}$ \\
\hline & $(0.595)$ & $(0.562)$ & $(0.537)$ & $(0.499)$ \\
\hline Booker*Hispanic & $1.687 * * *$ & $1.561 * * *$ & $1.226^{* * *}$ & $0.975 * *$ \\
\hline & $(0.446)$ & $(0.452)$ & $(0.427)$ & $(0.430)$ \\
\hline Booker*Other & $\begin{array}{c}2.711 * * * \\
(0.986)\end{array}$ & $\begin{array}{c}2.699 * * * \\
(0.987)\end{array}$ & $\begin{array}{c}2.840^{* * *} * \\
(0.964)\end{array}$ & $\begin{array}{c}2.431 * * \\
(1.067)\end{array}$ \\
\hline Booker*Non US Citizen & & $\begin{array}{c}-0.650^{*} \\
(0.334)\end{array}$ & $\begin{array}{c}-0.189 \\
(0.310)\end{array}$ & $\begin{array}{l}-0.341 \\
(0.362)\end{array}$ \\
\hline Booker*HS Grad & & $\begin{array}{c}-0.461^{*} \\
(0.272)\end{array}$ & $\begin{array}{l}-0.413 \\
(0.263)\end{array}$ & $\begin{array}{l}-0.254 \\
(0.261)\end{array}$ \\
\hline Booker*Some College & & $\begin{array}{c}-0.940 * * * \\
(0.357)\end{array}$ & $\begin{array}{c}-0.699 * * \\
(0.331)\end{array}$ & $\begin{array}{l}-0.303 \\
(0.312)\end{array}$ \\
\hline Booker*College Grad & & $\begin{array}{c}-2.544 * * * \\
(0.548)\end{array}$ & $\begin{array}{c}-1.902 * * * \\
(0.491)\end{array}$ & $\begin{array}{c}-1.639 * * * \\
(0.489)\end{array}$ \\
\hline Booker*\# Dependents & & $\begin{array}{l}-0.0530 \\
(0.0594)\end{array}$ & $\begin{array}{c}-0.0983 \\
(0.0612)\end{array}$ & $\begin{array}{c}-0.133 * * \\
(0.0613)\end{array}$ \\
\hline Booker*Female & & $\begin{array}{c}-0.734 * * \\
(0.362)\end{array}$ & $\begin{array}{l}-0.125 \\
(0.323)\end{array}$ & $\begin{array}{c}0.159 \\
(0.311)\end{array}$ \\
\hline Booker*Age & & $\begin{array}{c}-0.0151 \\
(0.0113)\end{array}$ & -0.00991 & -0.00792 \\
\hline Booker*Criminal History 2 & & & $\begin{array}{c}1.816^{* * *} * \\
(0.343)\end{array}$ & $\begin{array}{c}1.444 * * * \\
(0.369)\end{array}$ \\
\hline Booker*Criminal History 3 & & & $\begin{array}{c}2.218 * * * \\
(0.401)\end{array}$ & $\begin{array}{c}1.684 * * * \\
(0.431)\end{array}$ \\
\hline Booker*Criminal History 4 & & & $\begin{array}{c}1.664 * * * \\
(0.458)\end{array}$ & $\begin{array}{l}0.855^{*} \\
(0.470)\end{array}$ \\
\hline Booker*Criminal History 5 & & & $\begin{array}{c}2.528 * * * \\
(0.611)\end{array}$ & $\begin{array}{c}1.528 * * * \\
(0.581)\end{array}$ \\
\hline Booker*Criminal History 6 & & & $\begin{array}{l}-0.447 \\
(0.751)\end{array}$ & $\begin{array}{l}-1.092 \\
(0.735)\end{array}$ \\
\hline Observations & 679,159 & 679,159 & 679,159 & 679,159 \\
\hline R-squared & 0.741 & 0.741 & 0.742 & 0.742 \\
\hline
\end{tabular}

Notes: Data is from the USSC from 1994-2009. All regressions contain controls for offense type, and dummies for each offense level and criminal history combination. Column 1 replicates column 1 from Table II to show the baseline results. Column 2 includes interactions between defendant race and citizenship status, educational attainment, number of dependents, gender and age. Column 3 adds interactions between defendant race and final offense level and criminal history category. Finally, column 4 adds interactions between race and offense type. Regressions also contain district by sentencing year, and sentencing month fixed effects, and standard errors are clustered at the district level. Race specific trends are excluded because of limited variation, but magnitudes are unchanged when race trends are included. $* * *=$ significant at 1 percent level, $* *=$ significant at 5 percent level, * = significant at 10 percent level. 
Table V. Sentencing Patterns for Post Booker Judges

Subsample of Random Districts

\begin{tabular}{|c|c|c|c|c|c|c|c|}
\hline & $\begin{array}{c}(1) \\
\text { Sentence }\end{array}$ & $\begin{array}{c}\text { (2) } \\
\text { Above } \\
\text { Range }\end{array}$ & $\begin{array}{c}(3) \\
\text { Months } \\
\text { Above }\end{array}$ & $\begin{array}{c}\text { (4) } \\
\text { Below } \\
\text { Range }\end{array}$ & $\begin{array}{c}(5) \\
\text { Months } \\
\text { Below }\end{array}$ & $\begin{array}{c}\text { (6) } \\
\text { Within } \\
\text { Range }\end{array}$ & $\begin{array}{l}(7) \\
\text { Months } \\
\text { Within }\end{array}$ \\
\hline Post Booker Judge & $\begin{array}{l}-1.145 \\
(1.727)\end{array}$ & $\begin{array}{c}-0.00554 \\
(0.0113)\end{array}$ & $\begin{array}{l}-0.194 \\
(7.906)\end{array}$ & $\begin{array}{c}-0.00260 \\
(0.0166)\end{array}$ & $\begin{array}{c}0.987 \\
(1.355)\end{array}$ & $\begin{array}{l}0.00814 \\
(0.0142)\end{array}$ & $\begin{array}{c}-0.759 * * \\
(0.293)\end{array}$ \\
\hline Post Booker Judge*Black & $\begin{array}{l}5.440 * * \\
(2.587)\end{array}$ & $\begin{array}{c}0.0200 \\
(0.0149)\end{array}$ & $\begin{array}{c}6.293 \\
(6.918)\end{array}$ & $\begin{array}{l}-0.0101 \\
(0.0246)\end{array}$ & $\begin{array}{l}-2.103 \\
(1.751)\end{array}$ & $\begin{array}{r}-0.00994 \\
(0.0201)\end{array}$ & $\begin{array}{l}1.243 * * \\
(0.501)\end{array}$ \\
\hline Post Booker Judge*Hispanic & $\begin{array}{l}-0.625 \\
(1.574)\end{array}$ & $\begin{array}{c}0.0146 \\
(0.0228)\end{array}$ & $\begin{array}{l}-7.618 \\
(7.826)\end{array}$ & $\begin{array}{l}0.00725 \\
(0.0289)\end{array}$ & $\begin{array}{l}-0.797 \\
(1.826)\end{array}$ & $\begin{array}{l}-0.0219 \\
(0.0311)\end{array}$ & $\begin{array}{c}0.838 * * \\
(0.365)\end{array}$ \\
\hline Post Booker Judge* Other & $\begin{array}{l}0.218 \\
(2.625)\end{array}$ & $\begin{array}{c}0.0387 \\
(0.0306)\end{array}$ & $\begin{array}{l}-12.89 \\
(12.47)\end{array}$ & $\begin{array}{c}0.0343 \\
(0.0642)\end{array}$ & $\begin{array}{l}2.548 \\
(2.407)\end{array}$ & $\begin{array}{l}-0.0730 \\
(0.0607)\end{array}$ & $\begin{array}{l}2.862 \\
(2.300)\end{array}$ \\
\hline Booker & $\begin{array}{c}-2.835 * * \\
(1.074)\end{array}$ & $\begin{array}{l}-0.00253 \\
(0.0108)\end{array}$ & $\begin{array}{c}3.104 \\
(5.495)\end{array}$ & $\begin{array}{c}0.0849 * * * \\
(0.0199)\end{array}$ & $\begin{array}{l}-0.757 \\
(1.137)\end{array}$ & $\begin{array}{c}-0.0824 * * * \\
(0.0211)\end{array}$ & $\begin{array}{l}-0.303 \\
(0.369)\end{array}$ \\
\hline Booker*Black & $\begin{array}{l}1.693 * * \\
(0.696)\end{array}$ & $\begin{array}{c}0.0145 * * * \\
(0.00443)\end{array}$ & $\begin{array}{c}4.988 \\
(3.814)\end{array}$ & $\begin{array}{l}-0.0144 * \\
(0.00734)\end{array}$ & $\begin{array}{l}-1.061 \\
(0.689)\end{array}$ & $\begin{array}{c}-0.000126 \\
(0.00715)\end{array}$ & $\begin{array}{c}0.616^{* * * *} \\
(0.190)\end{array}$ \\
\hline Booker*Hispanic & $\begin{array}{c}0.744 \\
(0.547)\end{array}$ & $\begin{array}{c}0.000522 \\
(0.00420)\end{array}$ & $\begin{array}{l}-0.830 \\
(2.757)\end{array}$ & $\begin{array}{l}-0.0123 \\
(0.0139)\end{array}$ & $\begin{array}{l}0.0802 \\
(0.466)\end{array}$ & $\begin{array}{c}0.0118 \\
(0.0129)\end{array}$ & $\begin{array}{c}0.357 * * * \\
(0.130)\end{array}$ \\
\hline Booker*Other & $\begin{array}{c}0.154 \\
(0.874)\end{array}$ & $\begin{array}{c}0.00403 \\
(0.00914)\end{array}$ & $\begin{array}{c}5.574 \\
(6.971)\end{array}$ & $\begin{array}{l}-0.0118 \\
(0.0223)\end{array}$ & $\begin{array}{c}0.415 \\
(0.966)\end{array}$ & $\begin{array}{l}0.00775 \\
(0.0197)\end{array}$ & $\begin{array}{l}-0.545 \\
(0.358)\end{array}$ \\
\hline $\begin{array}{l}\text { Observations } \\
\text { R-squared }\end{array}$ & $\begin{array}{c}214,136 \\
0.784\end{array}$ & $\begin{array}{c}214,136 \\
0.194\end{array}$ & $\begin{array}{c}13,091 \\
0.367\end{array}$ & $\begin{array}{c}214,136 \\
0.244\end{array}$ & $\begin{array}{c}82,215 \\
0.736\end{array}$ & $\begin{array}{c}214,136 \\
0.202\end{array}$ & $\begin{array}{c}118,612 \\
0.985\end{array}$ \\
\hline
\end{tabular}

Notes: Data is from the matched USSC, TRAC, Federal Judicial Center data from 2000-2009 for courts with random assignment, excluding judges who formally retired prior to 2000. All regressions contain controls for offense type, and dummies for each offense level and criminal history combination. Regressions also contain district office by sentencing year, district court fixed effects, sentencing month fixed effects, and standard errors are clustered at the district level. $* * *=$ significant at 1 percent level, $* *=$ significant at 5 percent level, $*=$ significant at 10 percent level. 
Table VI. Treatment of Mandatory Minimums

\begin{tabular}{lcccc}
\hline \hline & $\begin{array}{c}(1) \\
\text { Mandatory } \\
\text { Minimum }\end{array}$ & $\begin{array}{c}\text { Binding } \\
\text { Minimum }\end{array}$ & $\begin{array}{c}(3) \\
\text { Safety } \\
\text { Valve }\end{array}$ & $\begin{array}{c}\text { Substantial } \\
\text { Assistance }\end{array}$ \\
\hline Booker*Black & -0.00320 & $0.0240 * * *$ & 0.0146 & -0.0132 \\
& $(0.00722)$ & $(0.00870)$ & $(0.00938)$ & $(0.0113)$ \\
Booker*Other & $-0.0174 * * *$ & -0.00262 & $0.0207 *$ & -0.00440 \\
& $(0.00569)$ & $(0.00703)$ & $(0.0116)$ & $(0.0122)$ \\
Booker*Hispanic & $-0.0231 * *$ & -0.0162 & 0.0268 & 0.0507 \\
& $(0.0112)$ & $(0.0192)$ & $(0.0322)$ & $(0.0308)$ \\
Black & $0.0490^{* * *}$ & 0.00678 & $-0.0193 * * *$ & $-0.0851 * * *$ \\
& $(0.00745)$ & $(0.00673)$ & $(0.00601)$ & $(0.0107)$ \\
Hispanic & $0.0477 * * *$ & $0.0240 * * *$ & 0.00275 & $-0.0858^{* * *}$ \\
& $(0.00543)$ & $(0.00536)$ & $(0.00940)$ & $(0.0101)$ \\
Other & -0.00959 & 0.00393 & -0.0145 & $-0.0613 * *$ \\
& $(0.00800)$ & $(0.0130)$ & $(0.0192)$ & $(0.0292)$ \\
Booker & 0.00158 & $-0.0349 * *$ & -0.0119 & 0.0299 \\
& $(0.00830)$ & $(0.0168)$ & $(0.0151)$ & $(0.0225)$ \\
Race Trends? & Yes & Yes & Yes & Yes \\
Observations & 816,564 & 244,273 & 162,294 & 221,320 \\
R-squared & 0.649 & 0.638 & 0.668 & 0.171 \\
\hline
\end{tabular}

Notes: Data is from the USSC from 1994-2009. All regressions contain controls for offense type, and dummies for each offense level and criminal history combination. Regressions also contain district by sentencing year, and sentencing month fixed effects, and standard errors are clustered at the district level. $* * *=$ significant at 1 percent level, $* *=$ significant at 5 percent level, $*=$ significant at 10 percent level. When the dependent variable is safety valve, data is from 1999-2009. 
Table VII. Sentencing Departures from the Guidelines

\begin{tabular}{lccccccc}
\hline \hline & $\begin{array}{c}(1) \\
\text { Sentence }\end{array}$ & $\begin{array}{c}(2) \\
\text { Above } \\
\text { Range }\end{array}$ & $\begin{array}{c}\text { Months } \\
\text { Above }\end{array}$ & $\begin{array}{c}(4) \\
\text { Below } \\
\text { Range }\end{array}$ & $\begin{array}{c}(5) \\
\text { Months } \\
\text { Below }\end{array}$ & $\begin{array}{c}(6) \\
\text { Within } \\
\text { Range }\end{array}$ & $\begin{array}{c}(7) \\
\text { Months } \\
\text { Within }\end{array}$ \\
\hline Booker*Black & $1.183^{* * *}$ & $0.00850 * *$ & 5.398 & -0.00933 & 0.427 & 0.000834 & 0.138 \\
& $(0.545)$ & $(0.00356)$ & $(3.360)$ & $(0.00842)$ & $(5.050)$ & $(0.00773)$ & $(0.118)$ \\
Booker*Hispanic & $1.997 * * *$ & 0.00478 & 4.171 & $-0.0367 * * *$ & $-7.968 * *$ & $0.0319 * * *$ & 0.139 \\
& $(0.377)$ & $(0.00442)$ & $(2.947)$ & $(0.00781)$ & $(3.139)$ & $(0.00793)$ & $(0.103)$ \\
Booker*Other & $1.764 * *$ & 0.00151 & $8.586 * *$ & 0.00498 & -8.031 & -0.00649 & 0.0395 \\
& $(0.842)$ & $(0.00666)$ & $(3.889)$ & $(0.0126)$ & $(5.446)$ & $(0.0119)$ & $(0.169)$ \\
Black & $1.604 * * *$ & -0.00328 & $-6.150 * *$ & $-0.0539 * * *$ & -6.696 & $0.0572 * * *$ & -0.0471 \\
& $(0.424)$ & $(0.00220)$ & $(2.789)$ & $(0.00809)$ & $(5.816)$ & $(0.00832)$ & $(0.0793)$ \\
Hispanic & $0.817 * * *$ & -0.00431 & $-5.826 * *$ & $-0.0390 * * *$ & 1.482 & $0.0433 * * *$ & $-0.182 * * *$ \\
& $(0.290)$ & $(0.00275)$ & $(2.249)$ & $(0.00948)$ & $(2.515)$ & $(0.0105)$ & $(0.0535)$ \\
Other & -0.299 & -0.00137 & -1.544 & -0.0212 & $7.618 * *$ & 0.0225 & -0.150 \\
& $(0.574)$ & $(0.00500)$ & $(2.951)$ & $(0.0148)$ & $(3.757)$ & $(0.0154)$ & $(0.118)$ \\
Booker & $-2.407 * * *$ & -0.00171 & -4.303 & $0.125 * * *$ & 1.707 & $-0.123 * * *$ & -0.242 \\
& $(0.899)$ & $(0.00936)$ & $(5.526)$ & $(0.0195)$ & $(4.912)$ & $(0.0212)$ & $(0.292)$ \\
Observations & 200,093 & 200,093 & 7,002 & 200,093 & 79,541 & 200,093 & 113,549 \\
R-squared & 0.784 & 0.088 & 0.432 & 0.188 & 0.906 & 0.166 & 0.989 \\
\hline
\end{tabular}

Notes: Data is from the USSC from 1994-2009, in the subset of cases for offenders in the lowest criminal history category and no weapon used. All regressions contain controls for offense type, and dummies for each offense level and criminal history combination. Regressions also contain district by sentencing year, and sentencing month fixed effects, and standard errors are clustered at the district level. $* * *=$ significant at 1 percent level, $* *=$ significant at 5 percent level, $*$ = significant at 10 percent level. 

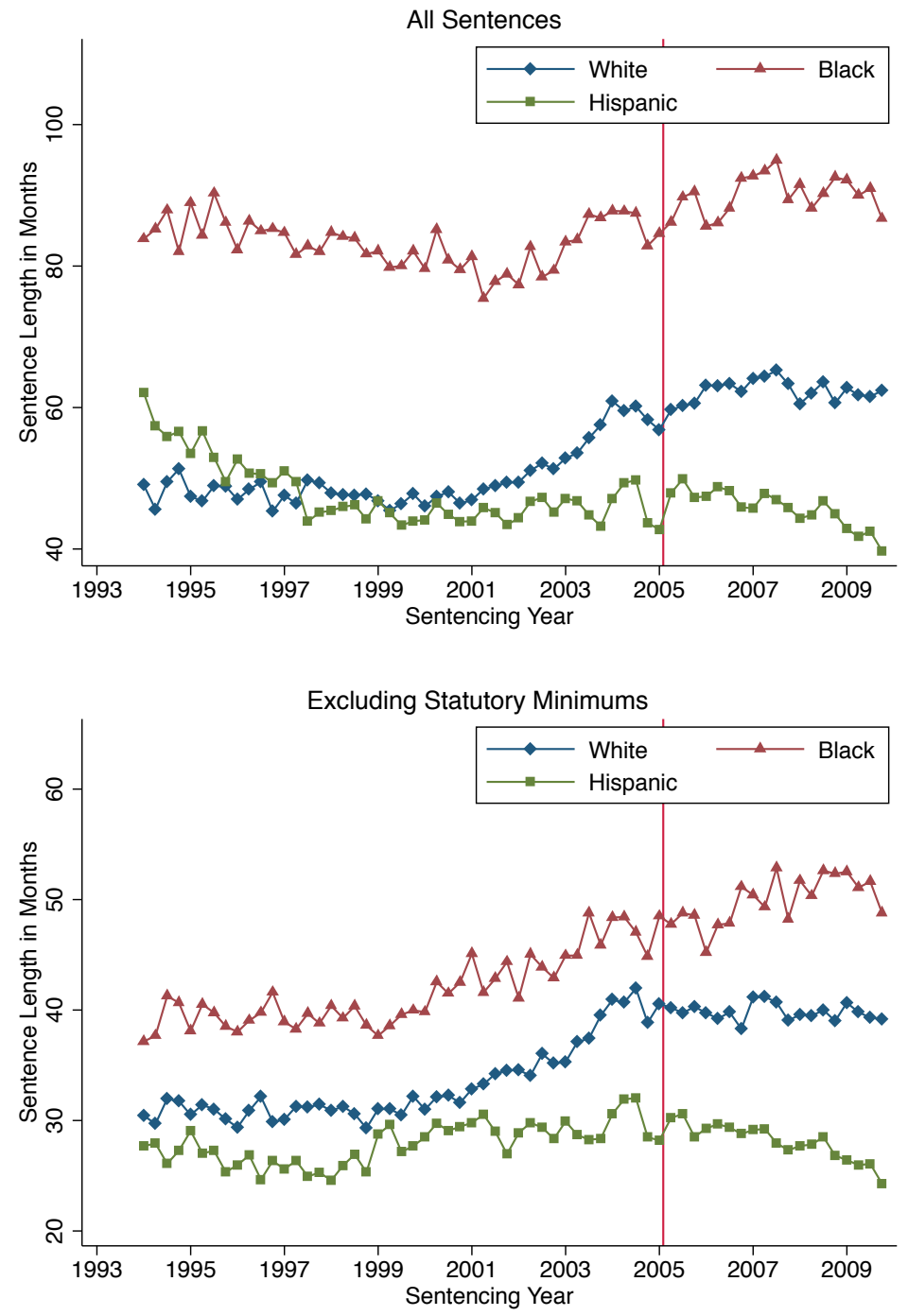

Figure I

Sentence Lengths in Months, by Defendant Race

Notes: Data is from the USSC from 1994-2009. Data points are quarterly averages. 


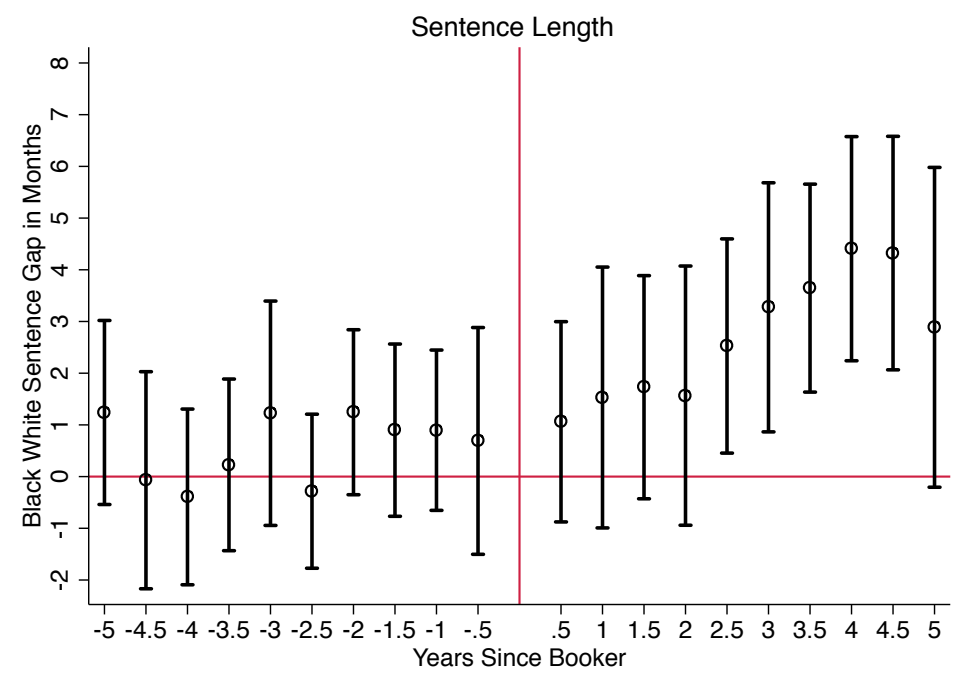

Figure II

Dynamics of Black White Gap, Sentence Length in Months

Notes: Data is from the USSC from 1994-2009. This figure shows coefficients from a dynamic DD regression identical to specification (1) in Table II, but with leads and lags for the five years before and five years after Booker, interacted with defendant race. The coefficients represent the differential sentence lengths between black and white defendants, compared to the pre-period (1994-1999). Error bars represent 95\% confidence intervals. Race specific trends are excluded because of limited variation, but magnitudes are unchanged when race trends are included. 



Figure III

Dynamics of Black White Departure Rates

Notes: Data is from the USSC from 1994-2009. This figure shows coefficients from a dynamic DD regression identical to specification (1) in Table II, but with leads and lags for the five years before and five years after Booker, interacted with defendant race. The coefficients represent the differential above and below range departure rates between black and white defendants, compared to the pre-period (1994-1999). Error bars represent 95\% confidence intervals. Race specific trends are excluded because of limited variation, but magnitudes are unchanged when race trends are included. 

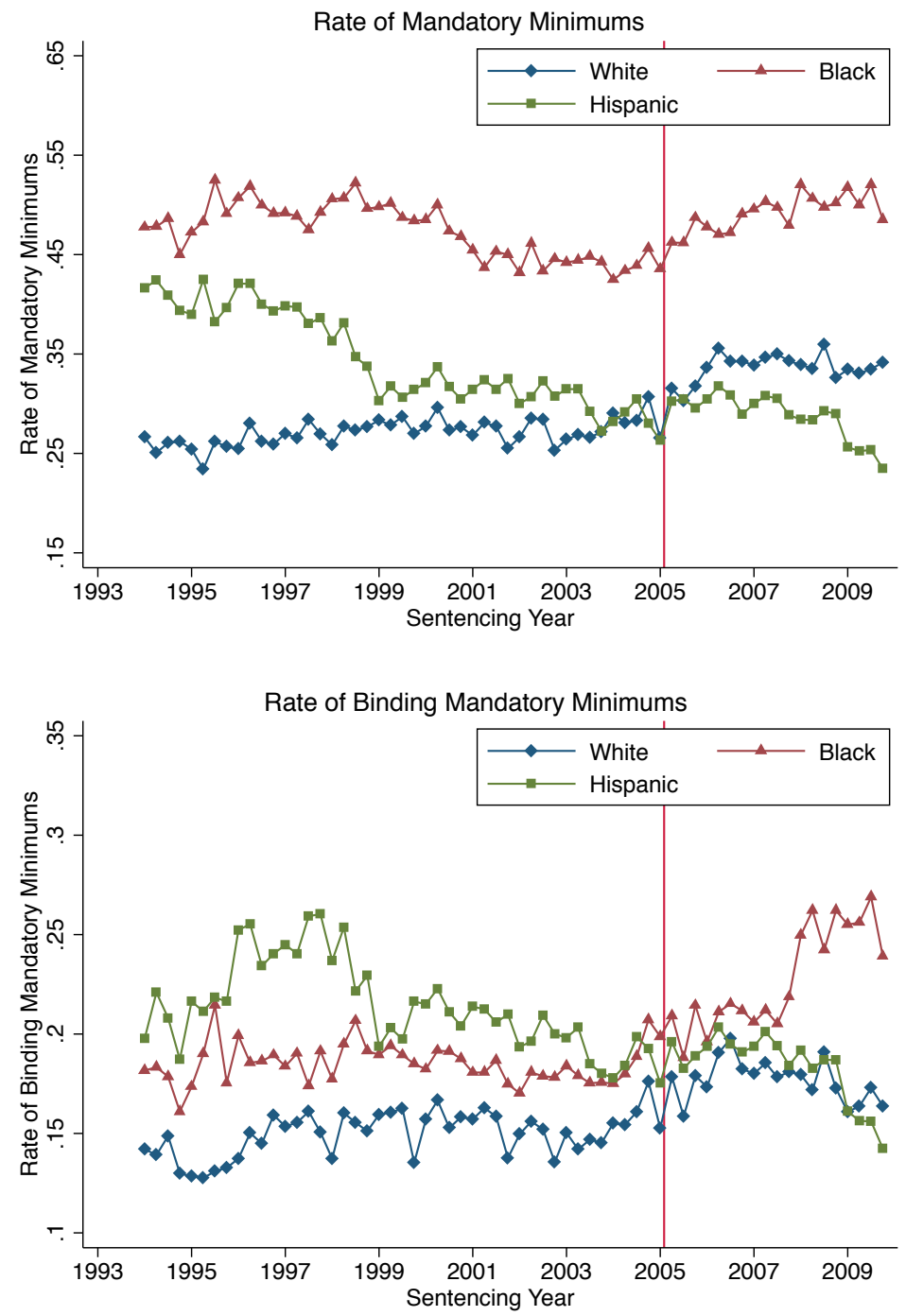

Figure IV

Rate of Mandatory Minimums, by Defendant Race

Notes: Data is from the USSC from 1994-2009. Data points are quarterly averages. 